NBSIR 77-1390

\title{
A Preliminary Examination of Building Regulations Adopted By the States and Major Cities
}

Patrick W. Cooke

Robert M. Eisenhard

Office of Building Standards and Codes Services Center for Building Technology Institute for Applied Technology National Bureau of Standards

Washington, D.C. 20234

November 1977

Draft Report

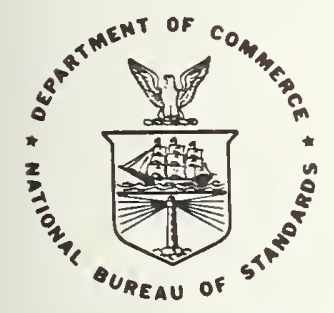

U.S. DEPARTMENT OF COMMERCE NATIONAL BUREAU OF STANDARDS 



\section{A PRELIMINARY EXAMINATION OF BUILDING REGULATIONS ADOPTED BY THE STATES AND MAJOR CITIES}

Patrick W. Cooke

Robert M. Eisenhard

Office of Building Standards and Codes Services Center for Building Technology Institute for Applied Technology National Bureau of Standards

Washington, D.C. 20234

November 1977

Draft Report

U.S. DEPARTMENT OF COMMERCE, Juanita M. Kreps, Secretary

Dr. Sidney Harman, Under Secretary Jordan J. Baruch, Assistant Secretary for Science and Technology NATIONAL BUREAU OF STANDARDS, Ernest Ambler, Acting Director 

This preliminary report has been prepared for review and comment on the completeness, accuracy, and utility of the information contained herein. The report will be distributed to cognizant State building regulatory agencies, State delegates of the National Conference of States on Building Codes and Standards, Inc. (NCSBCS), the model building code organizations, industry and other sectors of the building community.

The information presented in this report is not necessarily complete in its coverage of all the States and municipalities nor is it to be construed as being accurate or current in all aspects. The background data was collected from various sources over an extensive period of time.

The final report will reflect the corrections and additions offered by reviewers. Your timely critique and suggestions on the format, content, and utility of the preliminary report are solicited. Responses should be directed to:

Mr. Patrick W. Cooke

Office of Building Standards and Codes Services

Center for Building Technology, IAT

National Bureau of Standards

Washington, D.C. 20234 
Foreword ...................... . i i

1. Purpose and Scope . . . . . . . . . . . . . . . 1

2. Background . . . . . . . . . . . . . . . . 2

3. Format and Content of Summary Tables . . . . . . . . . . 3

\section{Figures}

1. Statewide and Major City Building Codes: Technical Basis

for Regulations in Existence . . . . . . . . . . . . . 5

2. Status of State Building Codes Adopted in the U.S. . . . . . 6

3. Status of State Mechanical Codes Adopted in the U.S. . . . . 7

4. Status of State Plumbing Codes Adopted in the U.S. . . . . . 8

5. Status of State Electrical Codes Adopted in the U.S. . . . . 9 9

6. Status of State Fire and Life Safety Codes Adopted

in the U.S. . . . . . . . . . . . . . . . . . . 10

7. Status of State Elevator Codes Adopted in the U.S. . . . . . 11

8. Status of State Gas Fitting Codes Adopted in the U.S. . . . . 12

9. Status of State Boiler and Pressure Vessel Codes Adopted

in the U.S. . . . . . . . . . . . . . . . . . 13

$\underline{\text { Tables }}$

1. Statewide Building Regulatory Programs -- Overview . . . . . 14

2.0 - 2.6 Statewide Building Code Programs . . . . . . . . . 15

3.0 - 3.6 Statewide Mechanical Code Programs . . . . . . . . 28

4.0 - 4.6 Statewide Plumbing Code Programs . . . . . . . . . 40

5.0 - 5.6 Statewide Electrical Code Programs . . . . . . . . 52

6.0 - 6.6 Statewide Fire and Life Safety Code Programs . . . . . 64

7.0 - 7.6 Statewide Elevator Code Programs . . . . . . . . 76

8.0 - 8.6 Statewide Gas Fitting Code Programs . . . . . . . 88

9.0 - 9.6 Statewide Boiler and Pressure Vessel Code Programs . . 100 


\section{CONTENTS}

\section{Page}

10. Building Regulations Administered and Enforced in

Major U.S. Cities . . . . . . . . . . . . . . 112

11. Agencies Responsible for Administration and Enforcement

of Building Regulatory Programs in Major U.S. Cities . . . . 115

Appendix

Publishers of Nationally Recognized Model Codes . . . . . . . . . 118 


\section{A Preliminary Examination of Building Regulations Adopted by the States and Major Cities}

\section{Purpose and Scope}

The primary objective of this preliminary report is to provide a compilation and summary of pertinent data on various aspects of State and major city building regulatory programs which will be useful to State and local building officials, to Delegates and committee members of the National Conference of States on Building Codes and Standards, Inc. (NCSBCS), and to various other segments of the building community.

This preliminary report is intended to present in a reasonably uniform manner a series of summary tables which describe the overall complex of regulatory codes and standards bearing on building construction and occupancy which have been adopted by the various states and certain major cities. The report deals specifically with the status of Statewide regulatory programs and the respective codes which have been adopted in the areas of building, mechanical, plumbing, electrical, fire and life safety, elevators, gas fittings, and boiler and pressure vessels. Coverage of other aspects of State adopted regulations such as energy conservation, elimination of architectural barriers to the physically handicapped, housing, health, noise abatement and historic preservation are also treated in less detail. Information available for presentation on municipal building regulations is limited to identification of the building, mechanical, plumbing, and electrical codes for the thirty cities that make up the membership of the Association of Major City Building Officials (AMCBO).

The summary descriptions are in the form of tables which incorporate information obtained from survey questionnaires and various other sources bearing on the subject of building regulation. Because of the rapid changes in the building regulatory field at both the State and local level, the actual status of the tabulated data may be changed by the time of publication. Also, States are introducing new legislation continually, and some laws providing for specific regulatory programs may have been enacted which are not reported herein. For this reason, key State officials and their respective administrative agencies are identified by address and telephone number in order that latest details on individual states may be obtained directly.

$1_{\text {There }}$ is an unfortunate problem with the meaning of the word "building" in this context. "Building code," for purposes of this report, refers primarily to only the structural aspects of construction, alteration, and use of buildings and not the installation of mechanical, plumbing, and electrical systems and equipment. This arrangement differs from other implied descriptions which perceive the "building code" as being all-encompassing. It is recognized, however, that some jurisdictions do utilize such composite building codes. 
Based on feedback information received from regulatory agencies, it is intended to update and reissue the tables in final form in the future. Accordingly, any corrections, additions, and suggestions that would update and/or improve the format, content, and utility of the tables are solicited and should be sent to:

\author{
National Bureau of Standards \\ Office of Building Standards and Codes. Services \\ Center for Building Technology \\ Building 226, Room B226 \\ Washington, D.C. 20234
}

\title{
2. Background
}

While the Constitution gives police power to the States, the enactment, administration, and enforcement of building codes and regulations has traditionally been a function of local government in the United States. There have been, however, an increasing number of programs and activities at both the State and Federal levels of government which have a direct impact on building codes and the regulation of various forms of building construction. These range from the adoption of various types of Statewide building regulatory programs in a number of States to the promulgation of mandatory Federal Mobile Home Construction and Safety Standards.

Despite developments at the State level toward code uniformity within individual States and advances in the performance approach for establishing building requirements, the form and content of building regulations as well as the attendant administration and enforcement activities vary widely from municipality to municipality and from State to State.

There are today approximately 14,000 individual communities in the United States issuing building permits on the basis of authorizing construction within their corporate boundaries. Many of these jurisdictions have rules and regulations related to buildings but they may not be comprehensive building codes covering all aspects of construction and occupancy. Some jurisdictions are actually using only a fire prevention code to regulate building construction.

The trend of enacting Statewide building code programs has helped reduce the variety of building-related codes toward a more workable number; however, significant variations still exist because of the structure of the various State programs as well as the resources individual States provide for such efforts. The approach taken in existing State programs may be one of the following:

- enforcement of mandatory Statewide codes with no jurisdictional exceptions

- promulgation of one of the State or model codes that may or may not be adopted by the political subdivisions of the State (with various possibilities of allowing or disallowing local modifications to the promulgated code) 
- promulgation of mandatory codes that exclude buildings to be used for certain occupancies; e.g., one- and two-family dwellings, agricultural buildings, etc.

- promulgation of codes that apply only to construction of Stateowned buildings or those financed with public funds

- promulgation of codes applicable to a single occupancy group

- promulgation of minimum Statewide codes that may be exceeded by local jurisdictions

At the State level, enforcement of building regulations, particularly those activities dealing with plan evaluation, approval and field inspection, is inconsistent. Much of the effort depends on the State-local interface. Most of the programs are administered at the State level with the actual enforcement activities being carried out by local jurisdictions. State functions often include code development and promulgation, training, certification of inspectors and for some codes plan approval for certain classes of buildings. Also, administration of specialized codes; i.e., plumbing, mechanical, etc., is sometimes dispersed among a number of different State agencies.

\section{Format and Content of Summary Tables}

The summary data are presented in tables, as well as maps (figures 1 thru 9), which graphically depict the extent of coverage for the various regulatory programs in effect. Figure 1 gives combined information with respect to overall code coverage for both states and the major cities.

\section{State Programs}

Table 1 provides an overview with respect to the general status, preemptive application and technical basis for each regulatory program adopted at the State level.

Table series 2.0 through 9.0 provide the detailed information for each code category. Within each detailed table, the information is organized in the following format:

- Enabling legislation

- Appiication and type of code

- Occupancy classification covered

- Code amendment procedures

- Administration and enforcement agencies

- Availability of regulations 
Appropriate notes and general remarks for each set of tables are also provided to further clarify the tabularized information. It should be pointed out that a number of States did not respond when the information for this report was collected. In these cases, the entry "No Statewide Code Adopted" is indicated on the tables.

\subsection{Major City Programs}

Tables 10 and 11 provide general information on the codes that have been promulgated in thirty municipalities in the areas of building, mechanical, plumbing and electrical regulation. 


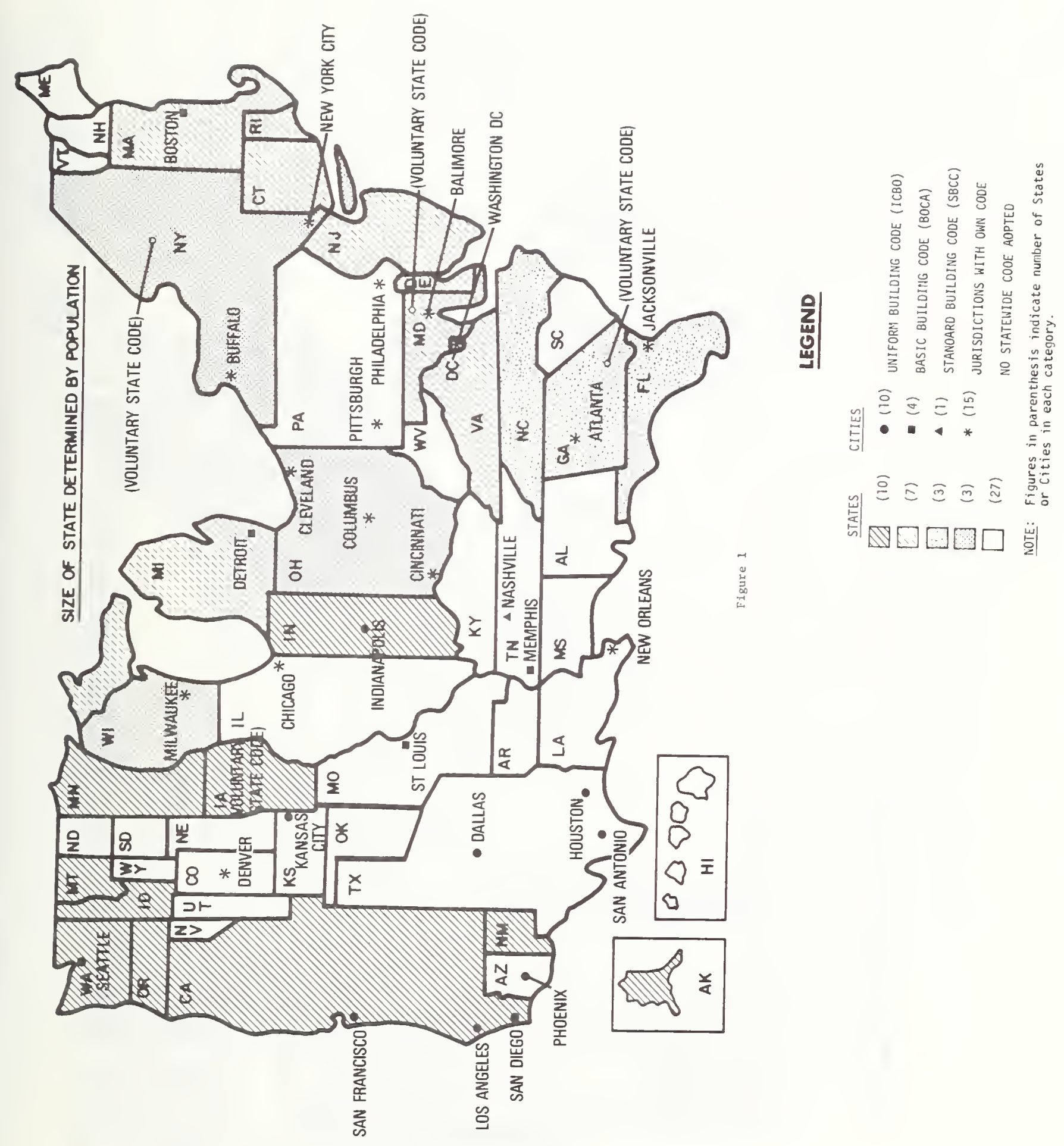




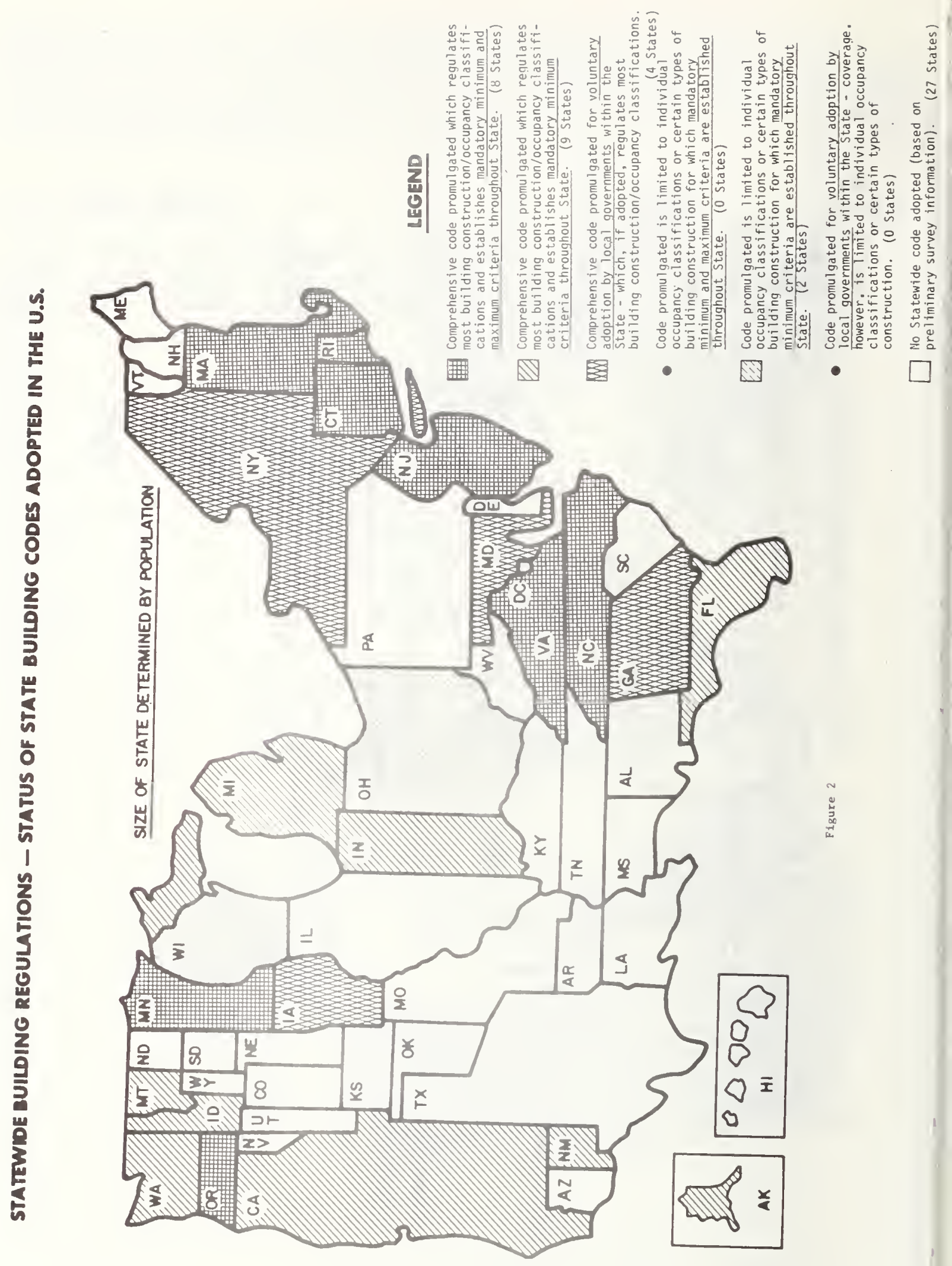




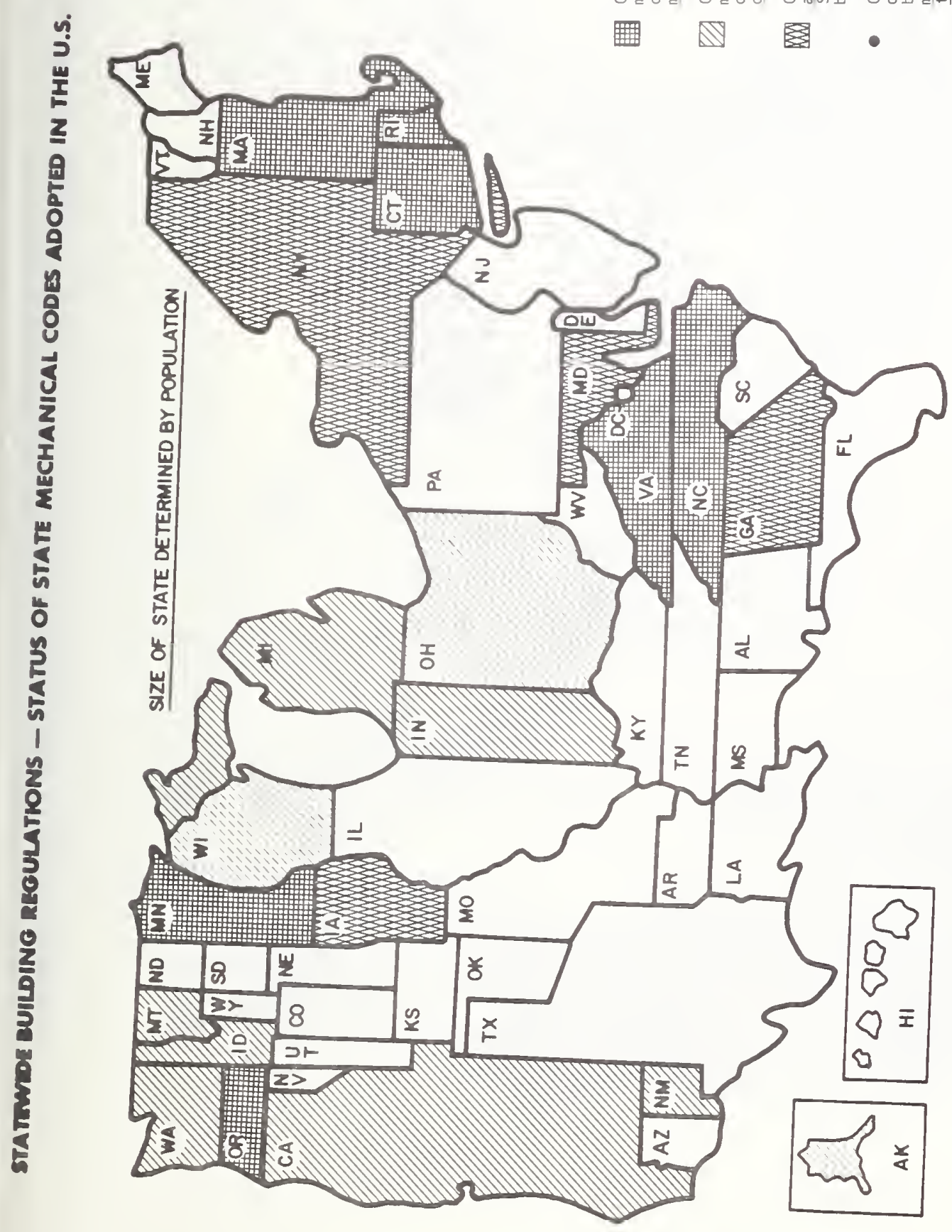




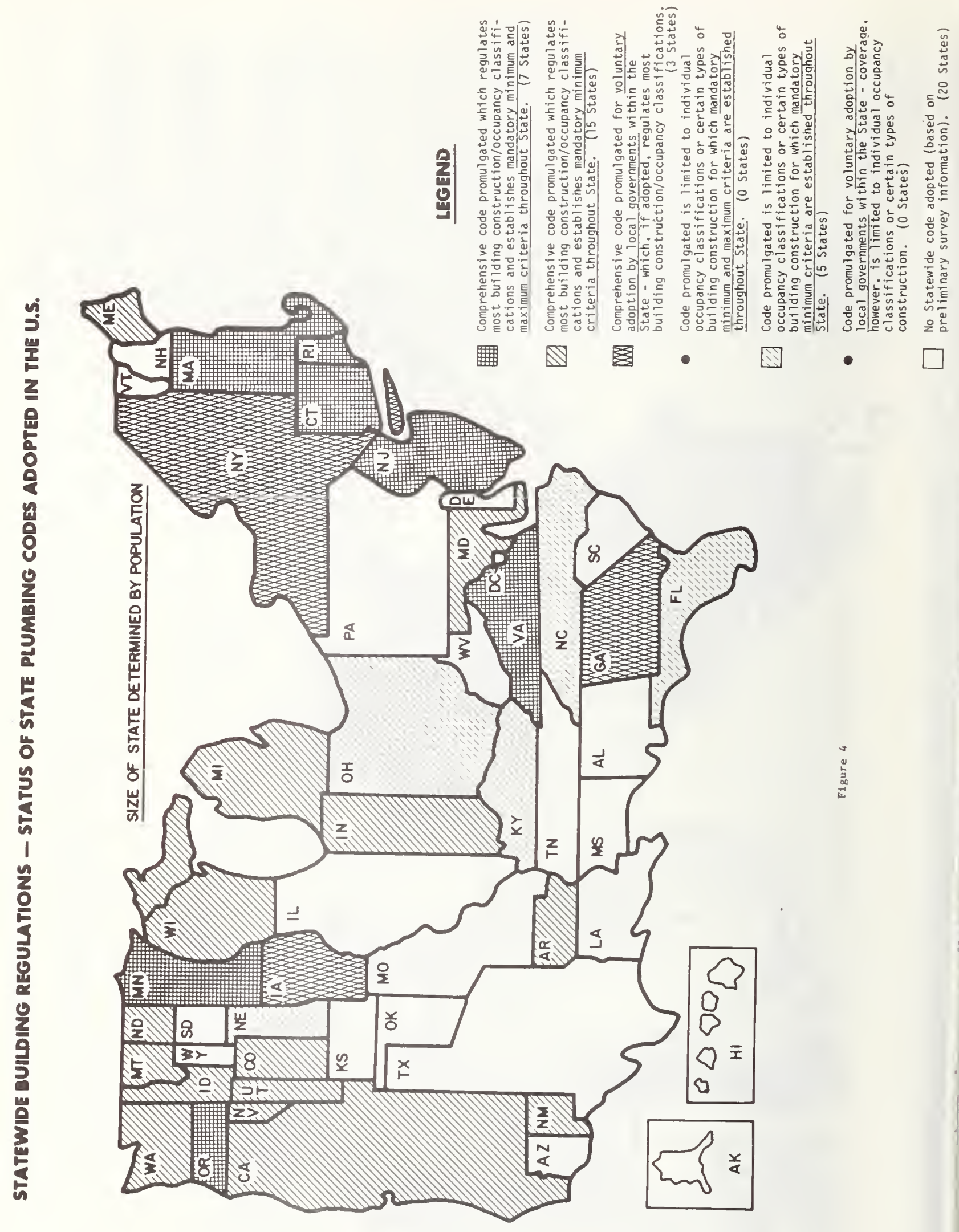




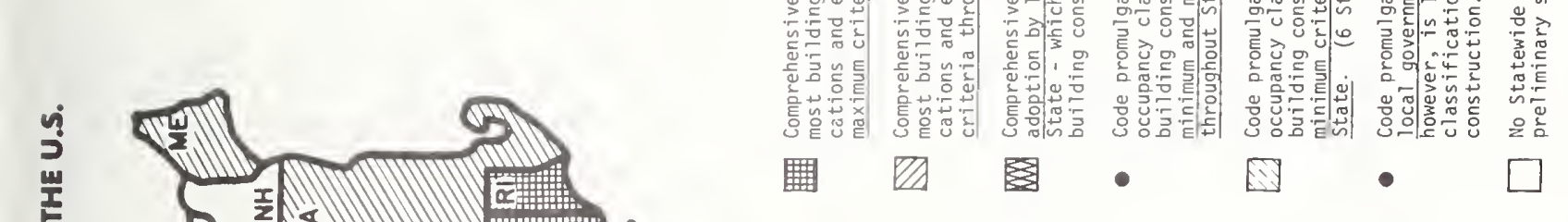




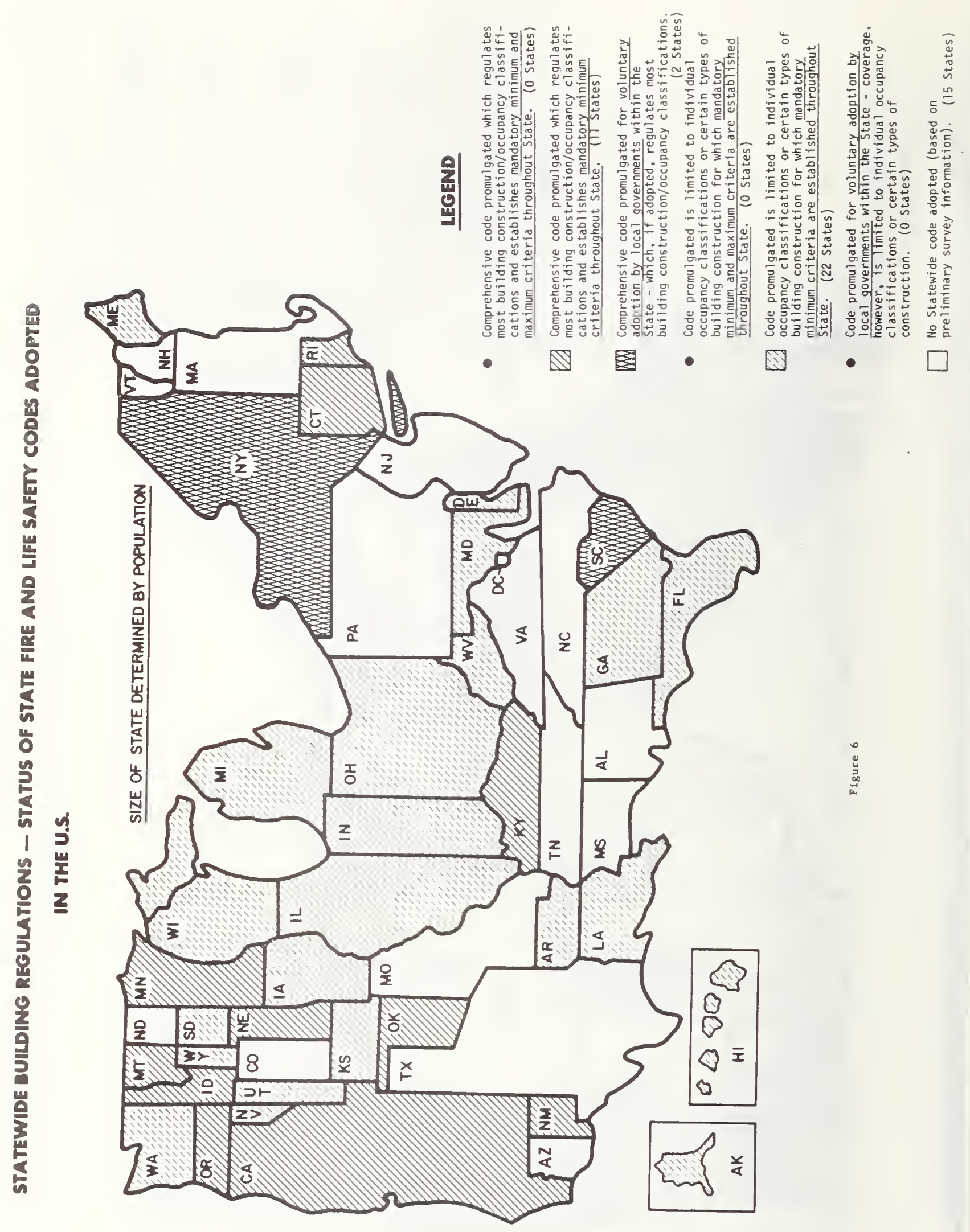




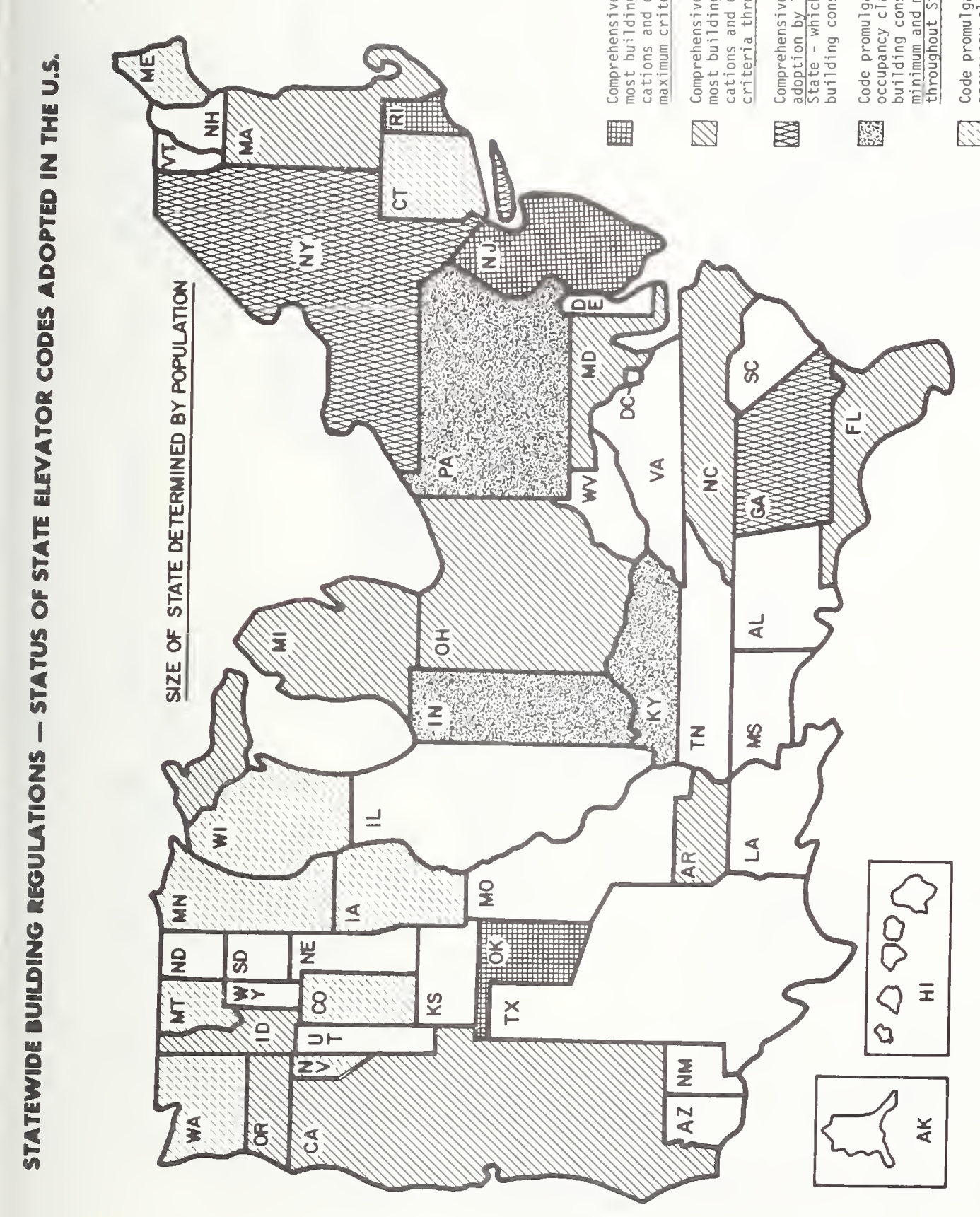




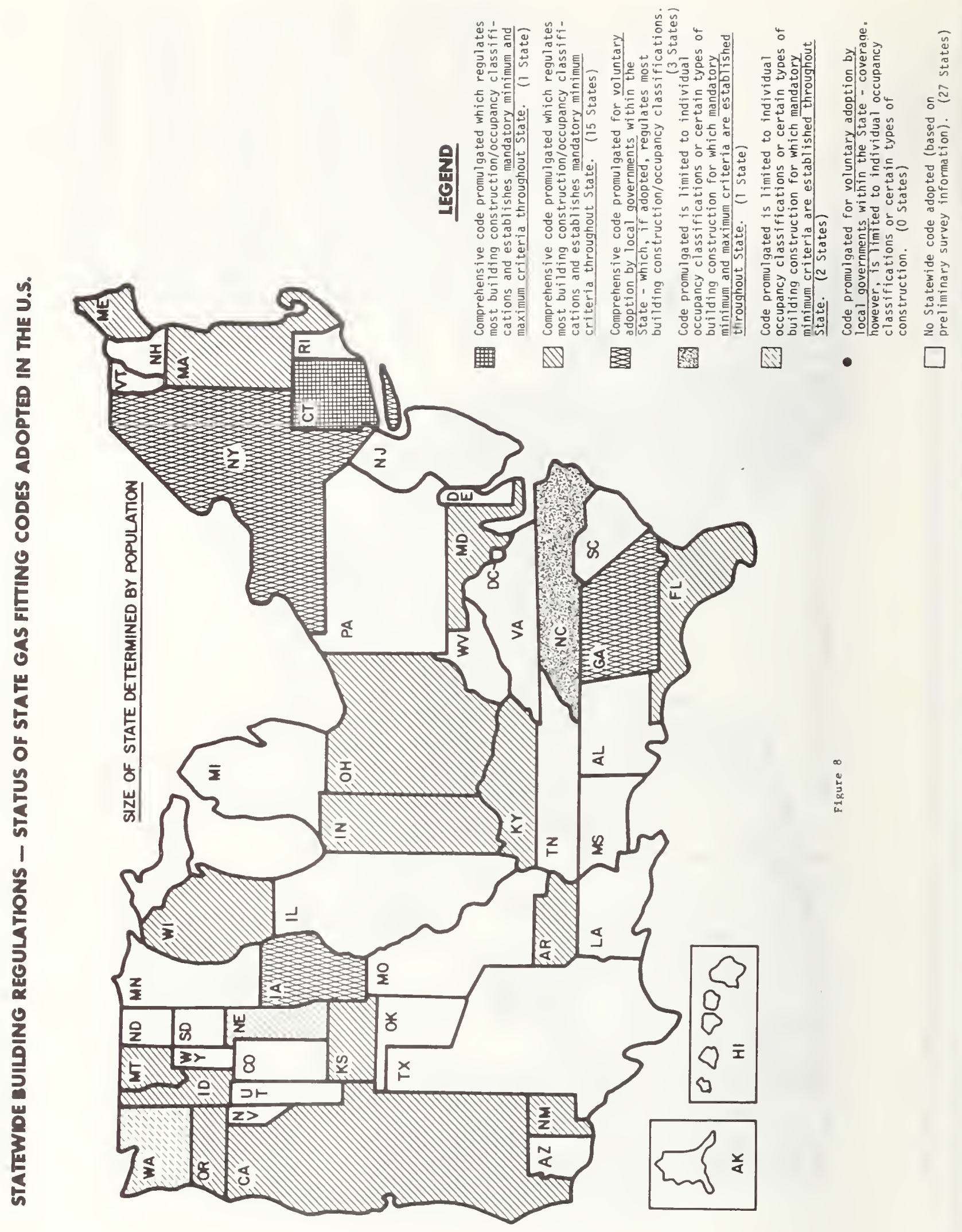


5

\section{这}
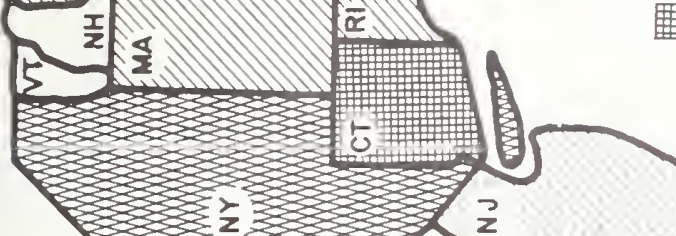

$z$
5
0
8
2
0
0
z
0
5
4
4
5
4
4
4
0
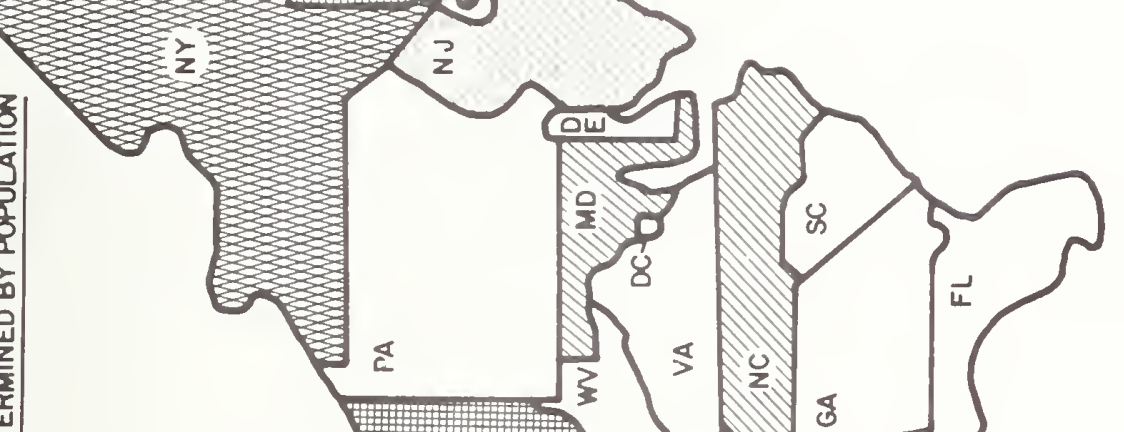

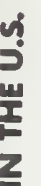

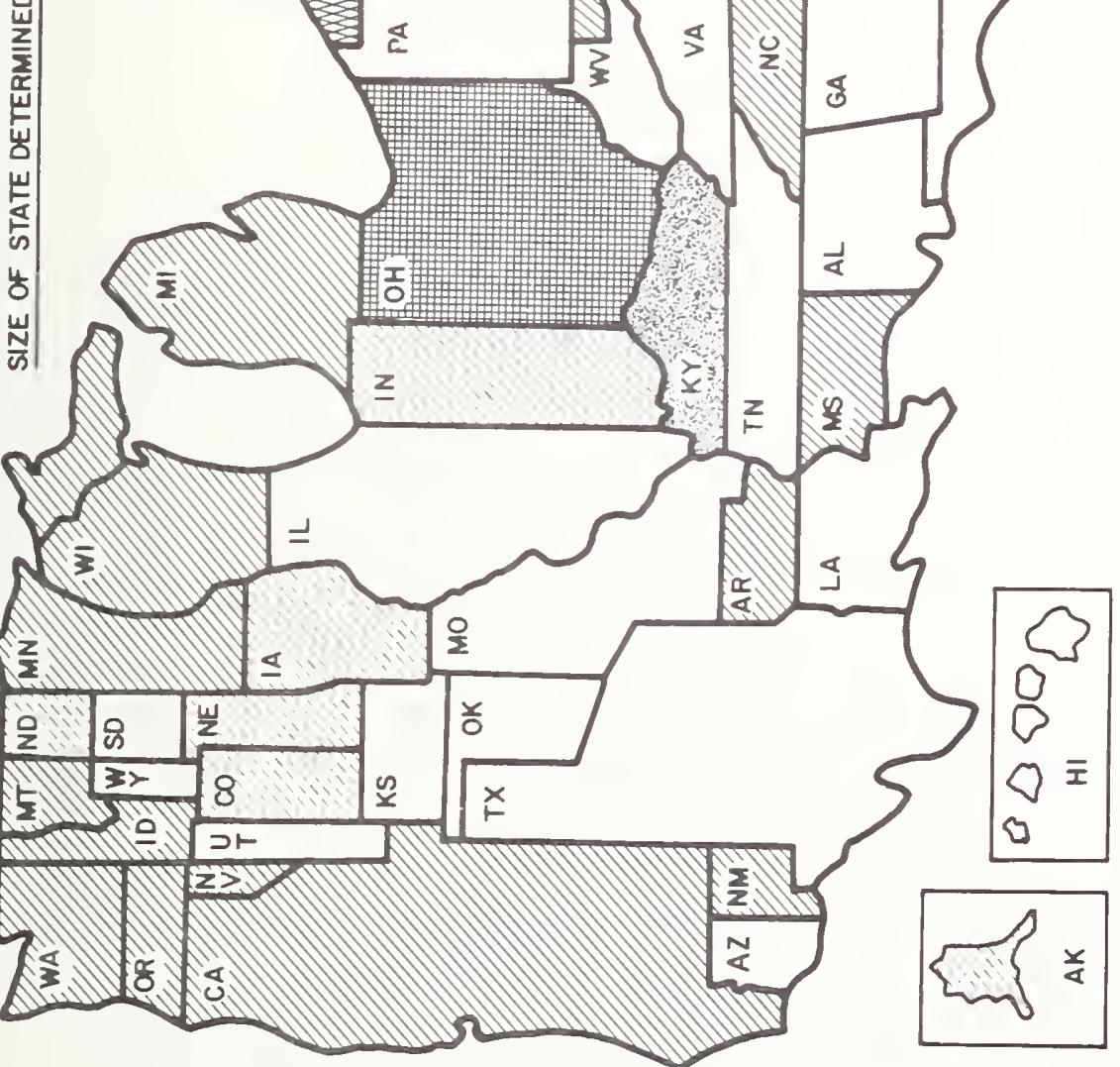




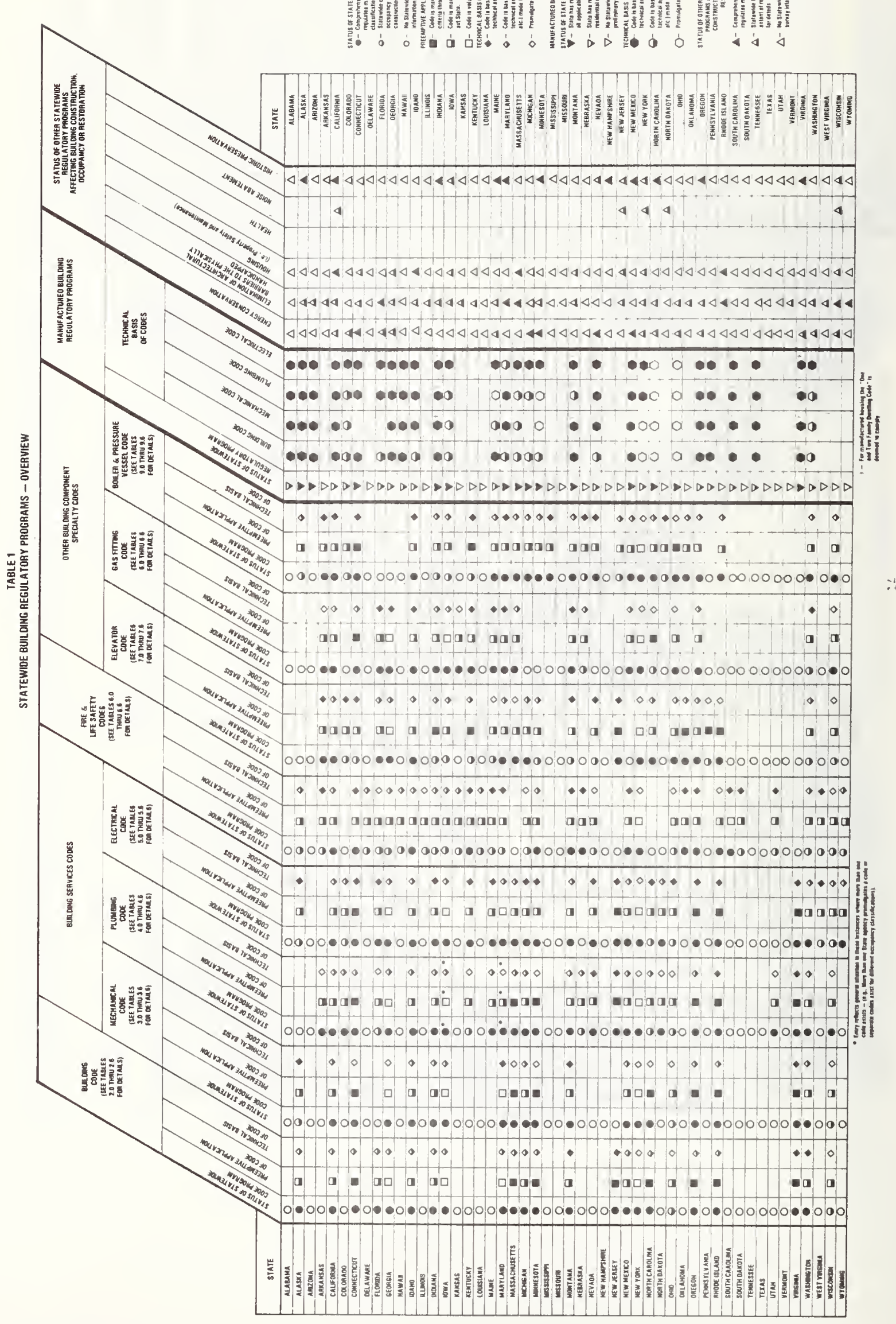




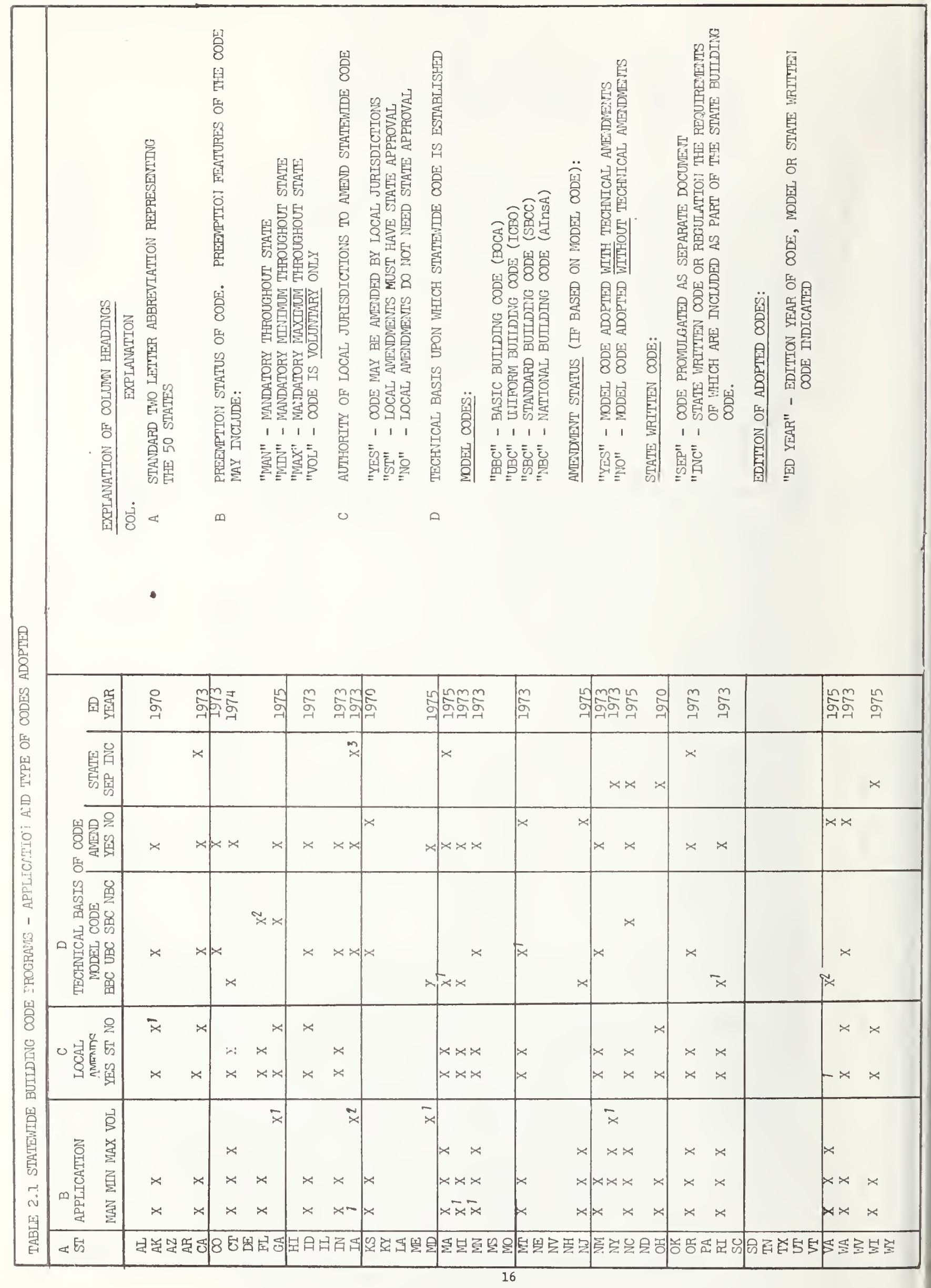




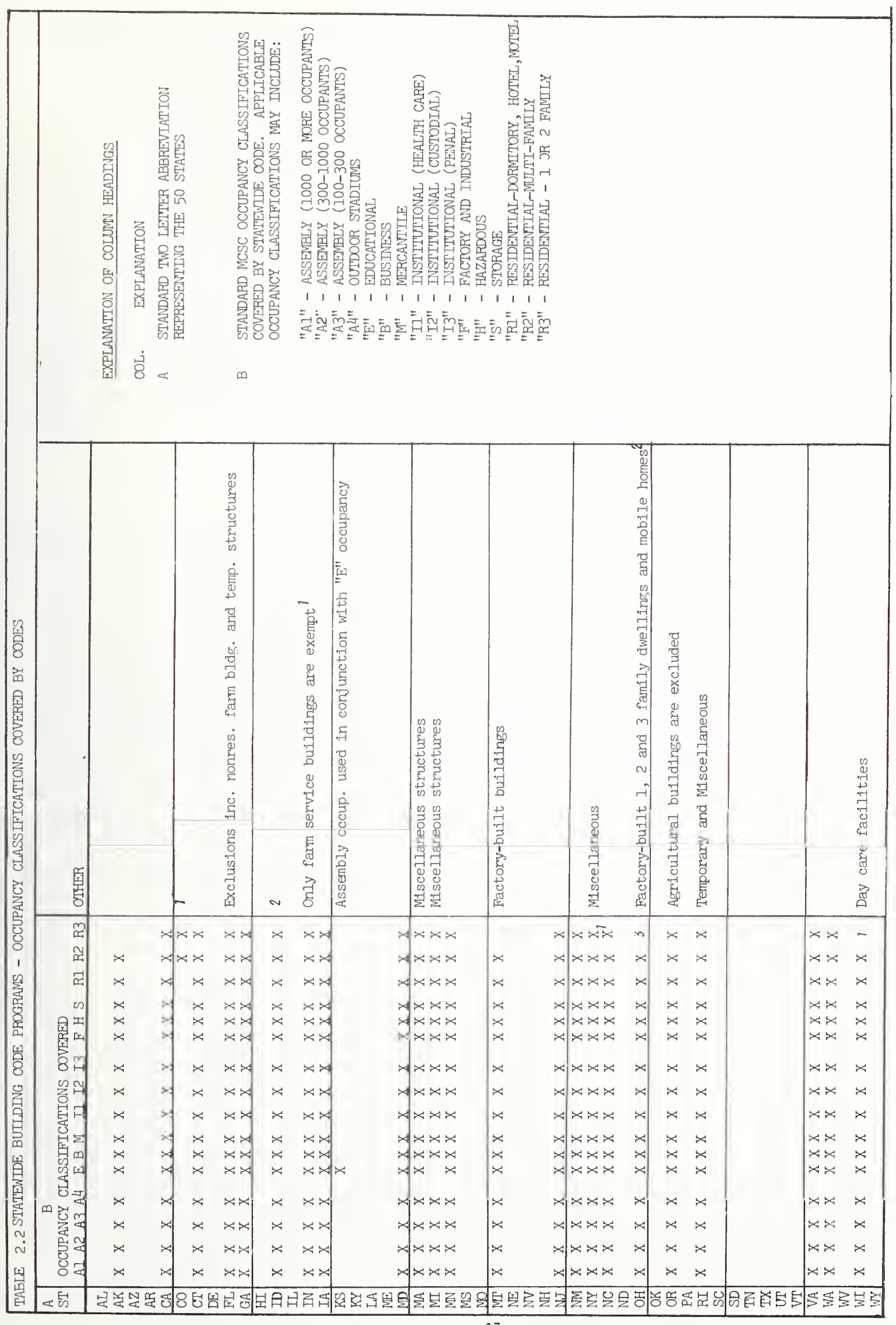




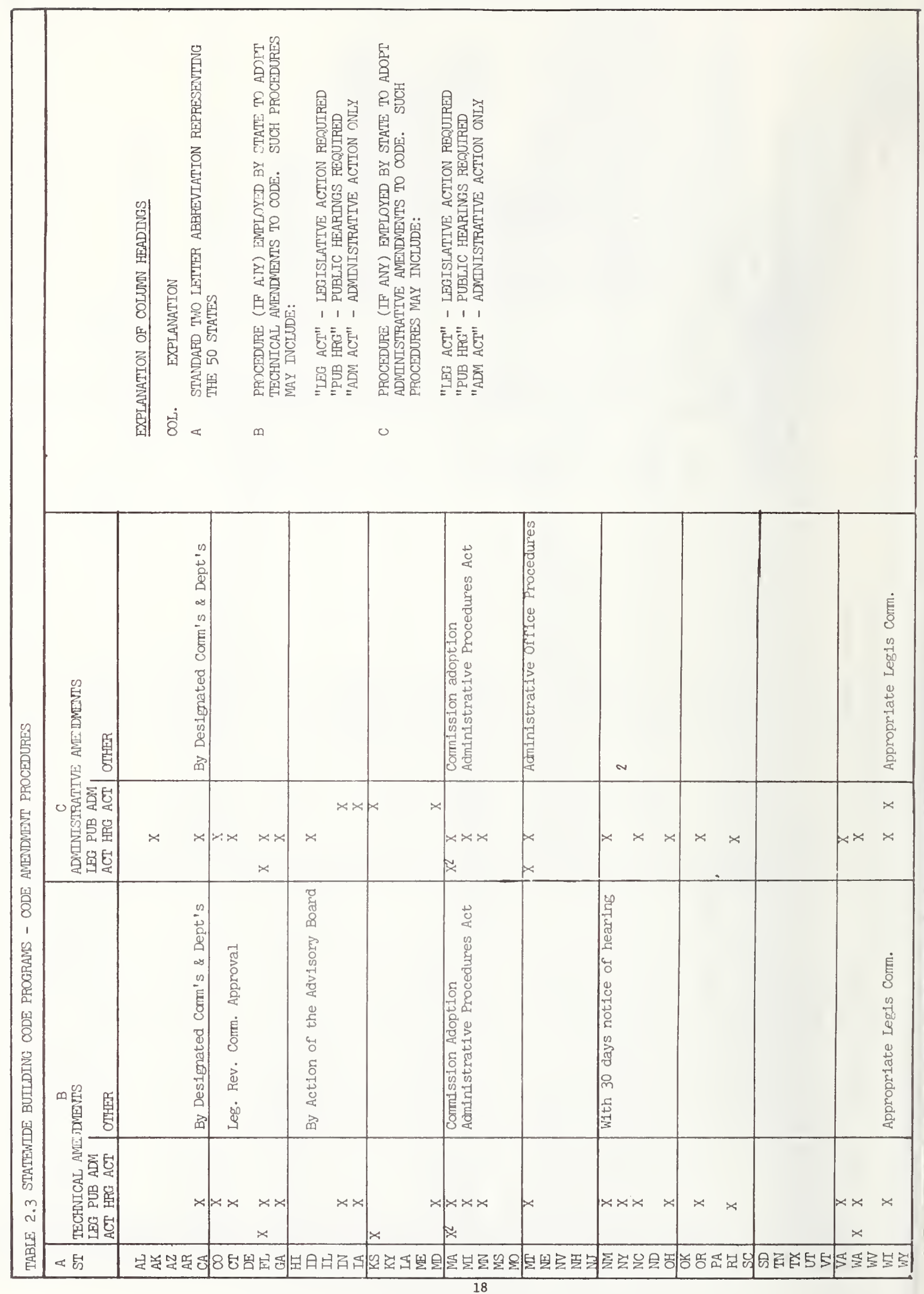




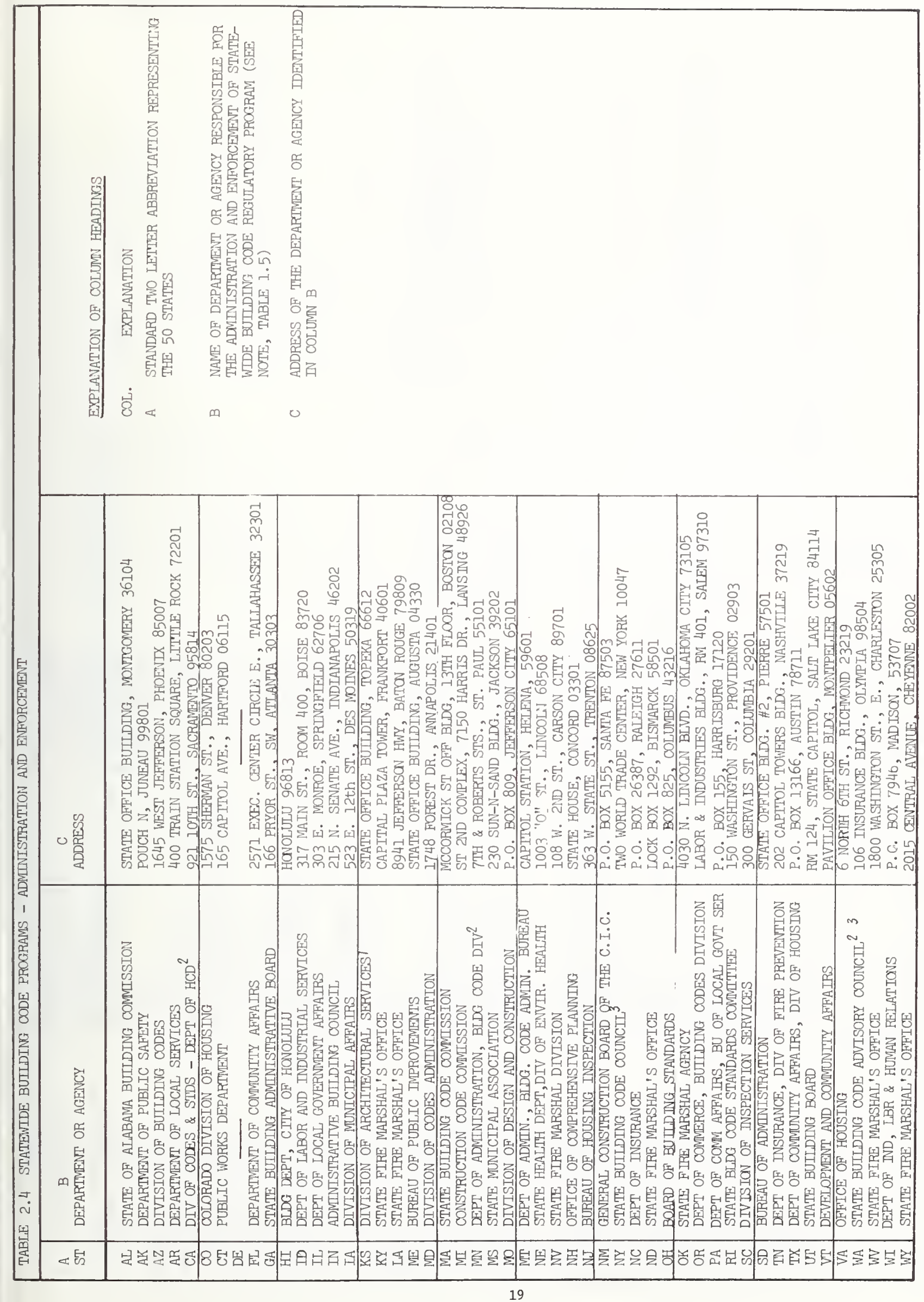



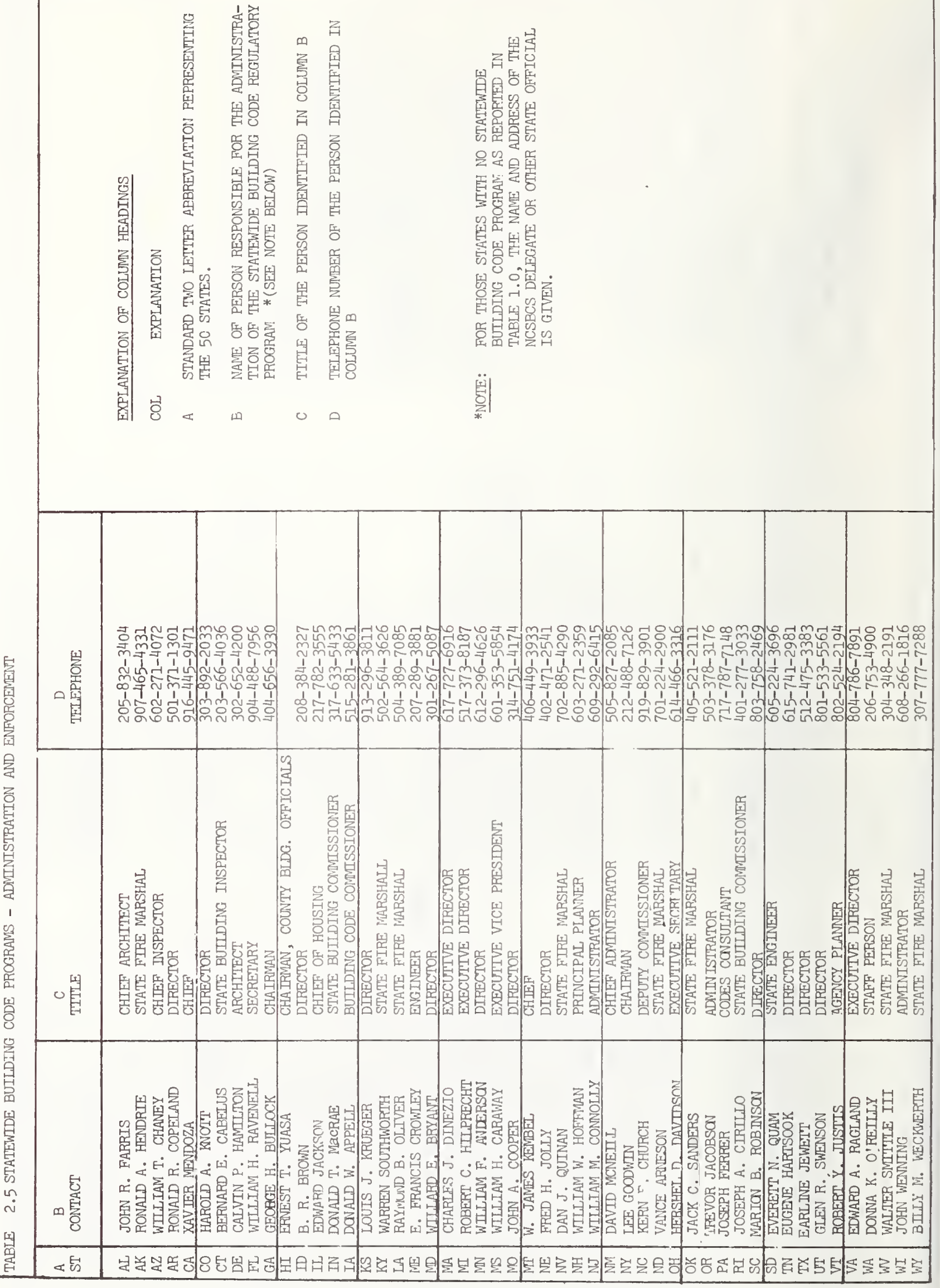


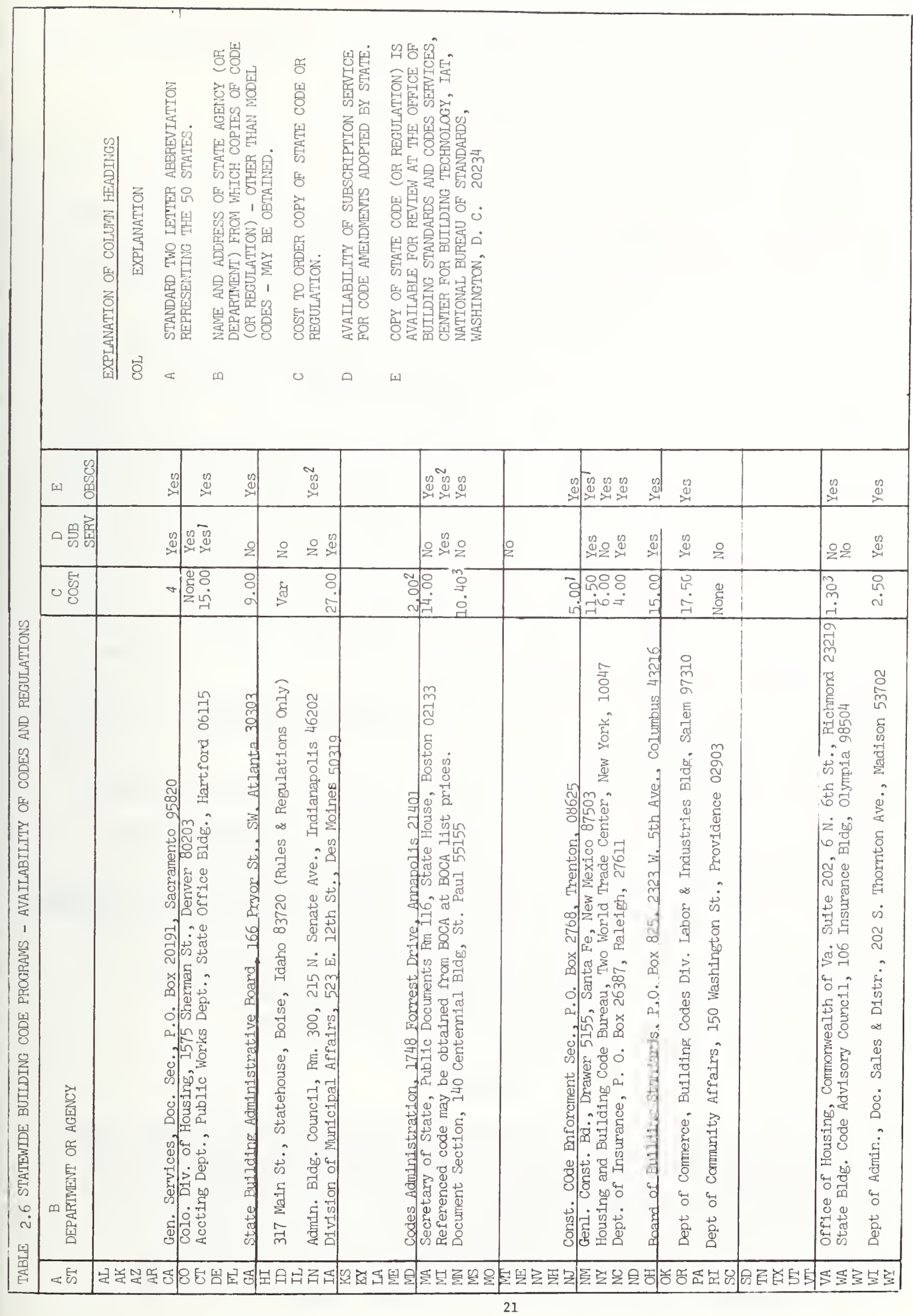


NOIES, GENERAL REMAK'KS

\section{ALABAN}

1. Legislation was irtroduced in the State Iegislature (SB 147) to provide for a state builajng code. The legislation did not pass.

2. All state-funded construction must comply with the Stindard building Code $(S B C C)$.

\section{ALASYA}

1. Arnendments imsi, ve equal to State Code Provisions.

$$
\text { ARJZONA }
$$

1. $75 \%$ of municipaljtjes have optionally adopted the Uniform bruilding Code. ARKANSAS

\section{CAL,IFORN TA}

1. I'itle 24 CAC contains all state building regulations. The following titles among others cover specific areas:

Title 25 - Residertial oncupancies and earthquake protection. Title 19 - Public Safety ritle 8 - Industrial Safety

2. Additional Administratior and Fnforcement Agencies/Department/Address State Fire Marshal, 7.171 Bowling Drive, Suite 800, Sacramento 95823 Department of Indust.rial Relations, Division of Industrial Safety, 455 Golden Gate Averue, San Francisco 94102

3. Additional Administration and Enforcement Agencjes/Contact/Title/Telephone

Philip (:. Favro, Fire Marshal, (y16) 32'2-2370

R. Wilkins, Chief, Division of Industrial Safety, (415) 557-1946

4. Complete T-24 $\$ 29.79$ Amendment Service $\$ 32.00$ per year T-25 \$11.24 Amendment Service $\$ 28.00$ per year Specific parts may be purchased separately.

\section{COLORADO}

1. The "Multiple-Dwe]ling Code of the State of Colorado" (H.B. 1055, 1970, otherwise known as the "Colorado Housing Act of 1970") applies to all multiple-family structures, rotels, and motels in those areas where building codes are not otherwise enforced.

\section{CONNECTICUT}

1. Cocie anendments are? providerd to code holders onjy. 


\section{DELAWARE}

\section{FLORIDA}

1. Florida has initiated the first step of a two phase program in the implementation of a minimum state building code. As of January 1, 1975, local governments and state agencies with building construction regulation responsibilities, that did not have in effect codes regulating the construction of buildings, were required to adopt the State Interim Building Code to regulate all types of construction. The State Minimm Building Codes were to be effective on a date set by the Legislature which was to be no later than January 1, 1977. However, due to the lack of State funding in 1976 the effective date has been postponed and the Interim Building Codes remain in effect.

2. For the State Interim Building Code - Local govermments were required to adopt one of the following: State Building Code, Basic Building Code, Uniform Building Code, National Building Code, EPCOT (Experimental Prototype City of Tomorrow) Code, South Florida Building Code and the One and Two Family Dwelling Code. If the One- and Two- Family Dwelling Code is used then one of the other recognized model codes must be adopted for regulation of other residential and non-residential structures.

\section{GEORGIA}

1. Extent adopted is unknown.

\section{HAWAII}

\section{IDAHO}

1. Effective date is $1-1-76$.

2. Exemptions are agricultural buildings, structures for industrial chemical plants and mineral extraction, temporary facilities used for construction, and telecommunications facilities.

\section{IILINOIS}

\section{INDIANA}

1. The State Fire Marshal Department is adopting and enforcing UBC Chapters 33, 38, 40 and 42 and added provisions for alarms and facilities for the handicapped. Also, the federally required NFPA 101 is applied to all institutional buildings. All buildings and structures, except Farm Service Buildings, are regulated by A.B.C. and Fire Marshal Codes, but the Oneand Two- Family Dwelling Code is enforced only by local officials for on-site work. Central plan review requires submittal to A.B.C. of at least two sets of documents. 
TABLE 2 STAIEWIDE BUIDING CODE PROGRAMS (continued)

\section{INDIANA (continued)}

2. One Indiana booklet contains amendments to the UBC and another the amendments to the One- and Two- Family Dwelling Code.

\section{IOWA}

1. Code is mandatory for state-owned buildings and factory-built structures.

2. Code is adopted by 7 cities and 1 county.

3. Reference to State Building Code document, Section 104A.

\section{KANSAS}

1. Enforcement of code is the responsiblity of State Fire Marshal, 211 West 7th St., Topeka, Kansas 66603, (telephone 913-296-3401).

\section{KENTUCKY}

1. Incorporates by reference the National Building Code, 1967 Edition, to regulate fire and panic aspects of construction.

\section{LOUISIANA}

\section{MAINE}

1. Maine reports to have an Act, adopted $10 / 69$, to authorize municipalities to incorporate by reference the provisions of nationally known technical codes prepared by State or regional agencies.

\section{MARYLAND}

1. Code is adopted by only 1 county as of $6 / 75$.

2. Maryland Codes Administrative Regulations only.

\section{MASSACHUSETTS}

1. Basic Code significantly modified (Articles 4, 7, 12, 19 - altered or additions made; Articles 15, 16, 17 - deleted). Also the One- and Two Family Dwelling Code with significant modifications.

2. Legislative action possible to preempt code.

\section{MICHIGAN}

1. The law permits a city, village, or township to exempt itself providing it adopts by ordinance a nationally recognized model code. Most commities have elected to stay with the state Code (Basic modified) while some have adopted Basic directly and others the UBC.

2. Michigan General Rules including amendments to the Basic Code. 
TABIE 2 STAIEWIDE BUIDDING CODE PROGRAMS (continued)

\section{MINNESOTA}

1. Code exceptions apply to farm dwellings, agricultural buildings, and municipalities not having standards as of July l, 1972.

2. Enforcement of code is responsibility of local municipalities throughout State.

3. Amendments $\$ 1.56$.

\section{MISSISSIPP I}

1. The State Building Commission has adopted, as a matter of policy, that the Standard Building Code (SBCC) be followed in the design of public construction throughout the state that comes under its jurisdiction.

\section{MISSOURI}

1. The Division of Design and Constmuction uses the Basic Building Code in the design and construction of State facilities throughout Missouri.

\section{MONTANA}

1. Also use the One- and Two- Family Dwelling Code.

NEBRASKA

NEVADA

1. The Nevada State Public Works Board enforces the Uniform Building Code in all State building construction and capitol improvement projects. Also, the UBC is the code most widely in use throughout the state in the larger populated cities and counties.

NEW HAMPSHIRE

NEW JERSEY

1. New Jersey Uniform Construction Code Regulations relate to Administration and Enforcement and Building, Plumbing, Electrical and Fire Protection Subcodes.

NEW MEXICO

1. Amendments to the 1973 UBC.

NEW YORK

1. The 642 municipalities include .54 cities, 277 towns, 311 villages (77\% of municipalities over 5000 population). 
TABIE 2 STALEWIDE BUIIDING CODE PROGRAMS (continued)

NEW YORK (continued)

2. Administration of code is municipal responsibility as per local law or ordinance.

3. Enforcement is responsibility of municipalities.

\section{NORTH CAROLINA}

1. One- and Two- Family Dwellings are covered by the North Carolina Uniform Residential Building code. It is a mandatory maximu/minimum and can be amended by local governments only with State approval.

NORTH DAKOTA

OHIO

1. Factory-built of closed construction regulated for all occupancies by state certification, inspection and labeling. Mobile homes permitted as single family dwellings only. $\mathbb{M H}$ and RV 3rd party certified, state monitored.

2. Agricultural buildings incident to land use excluded. Federal bujldings owned by and used for a function of Federal Govermment excluded.

3. Ohio also has a voluntary 1,2 and 3 family Model Dwelling House Code for voluntary adoption. It may be amended locally without State approval. It was adopted in 1972 and its cost is $\$ 6.00$.

\section{OKLAHOMA}

1. The National Building Code (1967 Edition) has been promulgated by the State Fire Marshal Cormission to regulate life safety aspects. Cities that have capability to enforce may adopt any of the four model codes.

\section{OREGON}

\section{PENNSYLVAN IA}

\section{RHODE ISLLAND}

1. The One- and Two- Family Dwelling Code is also used.

SOUTH CAROLINA

1. State law H2730 established a Building Code Council to promote uniformity and promote the adoption of the Standard Building Code (SBCC) by local jurisdictions. 
TABIE 2 STAIEWIDE BUIDING CODE NROGRAMS (continued)

SOUTH DAKOI'A

TEINNESSEE

TEXAS

UTAH

VERMONT

1. Act 196 of the 1973 Adjourned session stipulates that if a municipality does adopt a building code, it must adopt the National Building Code.

VIRGINIA

1. No local amendments.

2. Chapter 6 - Code of Virginia - Uniform Statewide Building Code Article 1 - General Provisions - Sec. 36-97 through 36-107, Article 2 Board of State Building Code Technical Review-Sec. 36-108 through 36-119. Adopts the 19/5-Basic Building Code, Plumbing Code, Mechanical Code, 19'15 One- and Two- Family Code and 1975 National Electric Code.

3. Cost of State Supplement and Adopting Ordinance is $\$ 1.30$.

\section{WASHINGTON}

1. State Building Code Act codified as Chapter 19.27 RCW (Revised Code of Washington).

2. Administration and enforcement is the responsibility of the local jurisdiction.

3. State Building Code Advisory Council currently promulgating new Barrier Free Design administrative rules and regulations for adoption on July $1,1976$.

$$
\text { WEST VIRGINIA }
$$

1. The National Building Code (1967 Edition) has been promulgated by the State Fire Marshal to regulate fire safety aspects of buildings.

\section{WISCONSIN}

1. Legislation providing for a Statewide code for 1 and 2 family dwellings passed in 1976. Code is under consideration.

WYOMING 


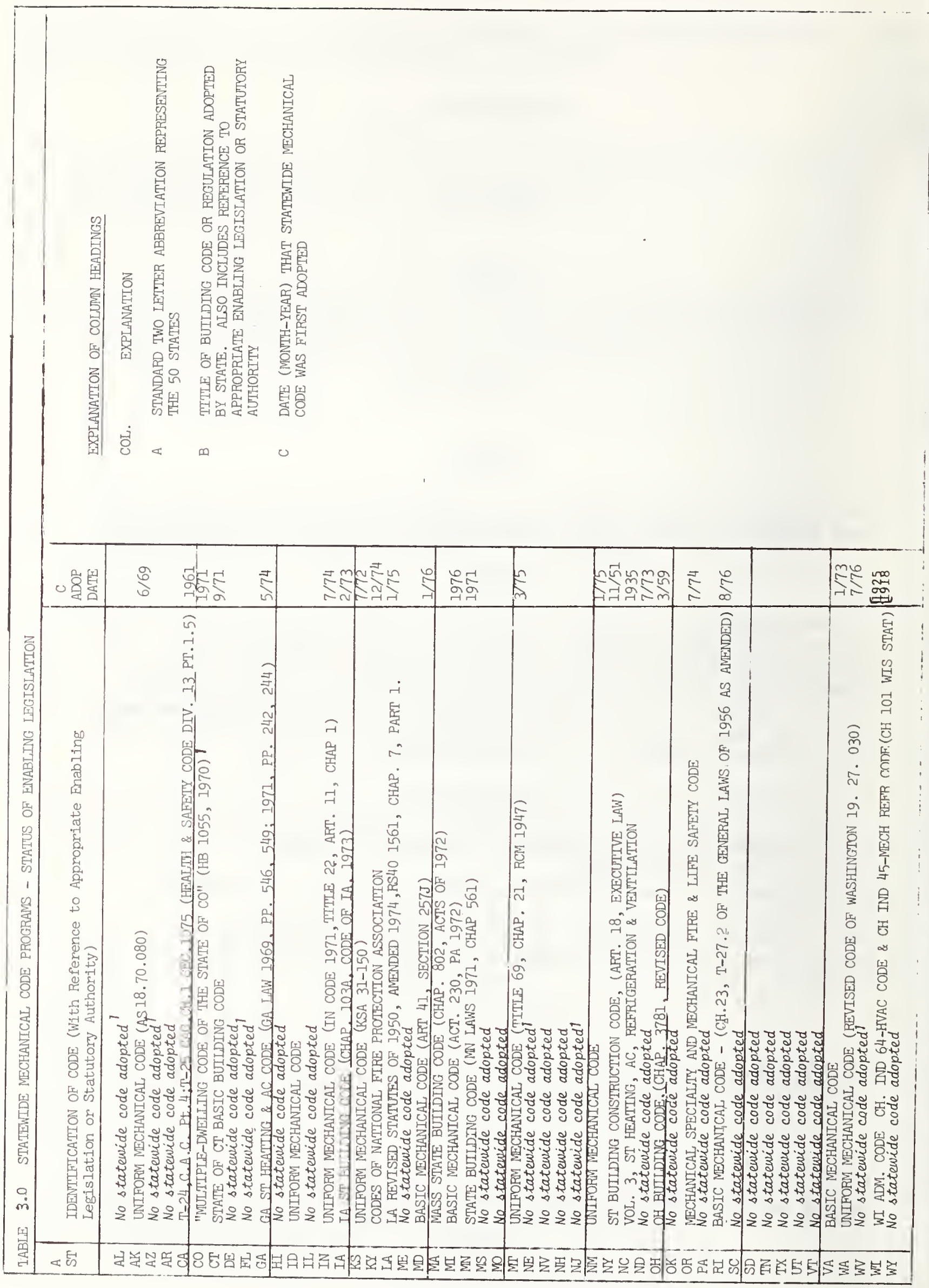




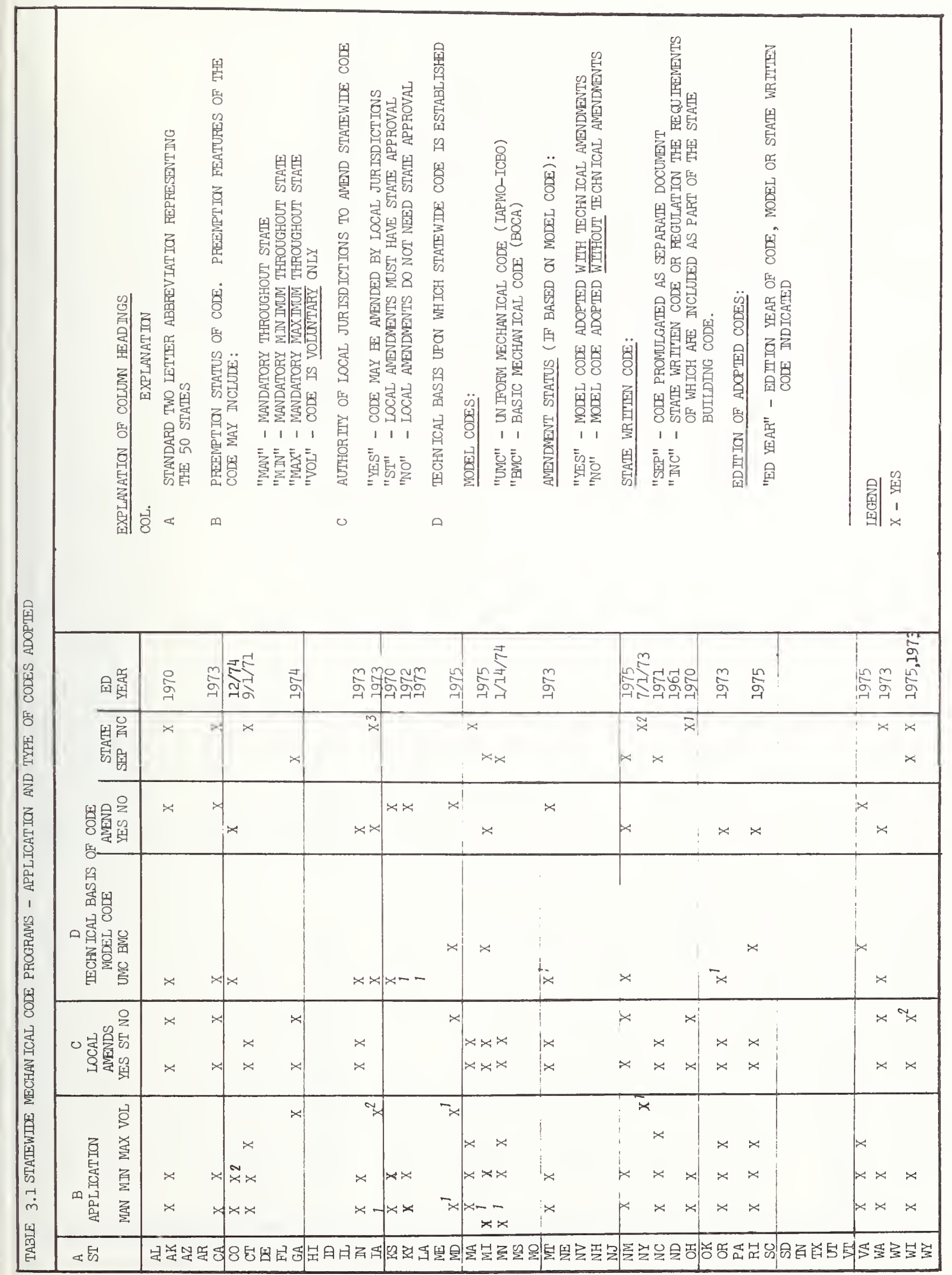




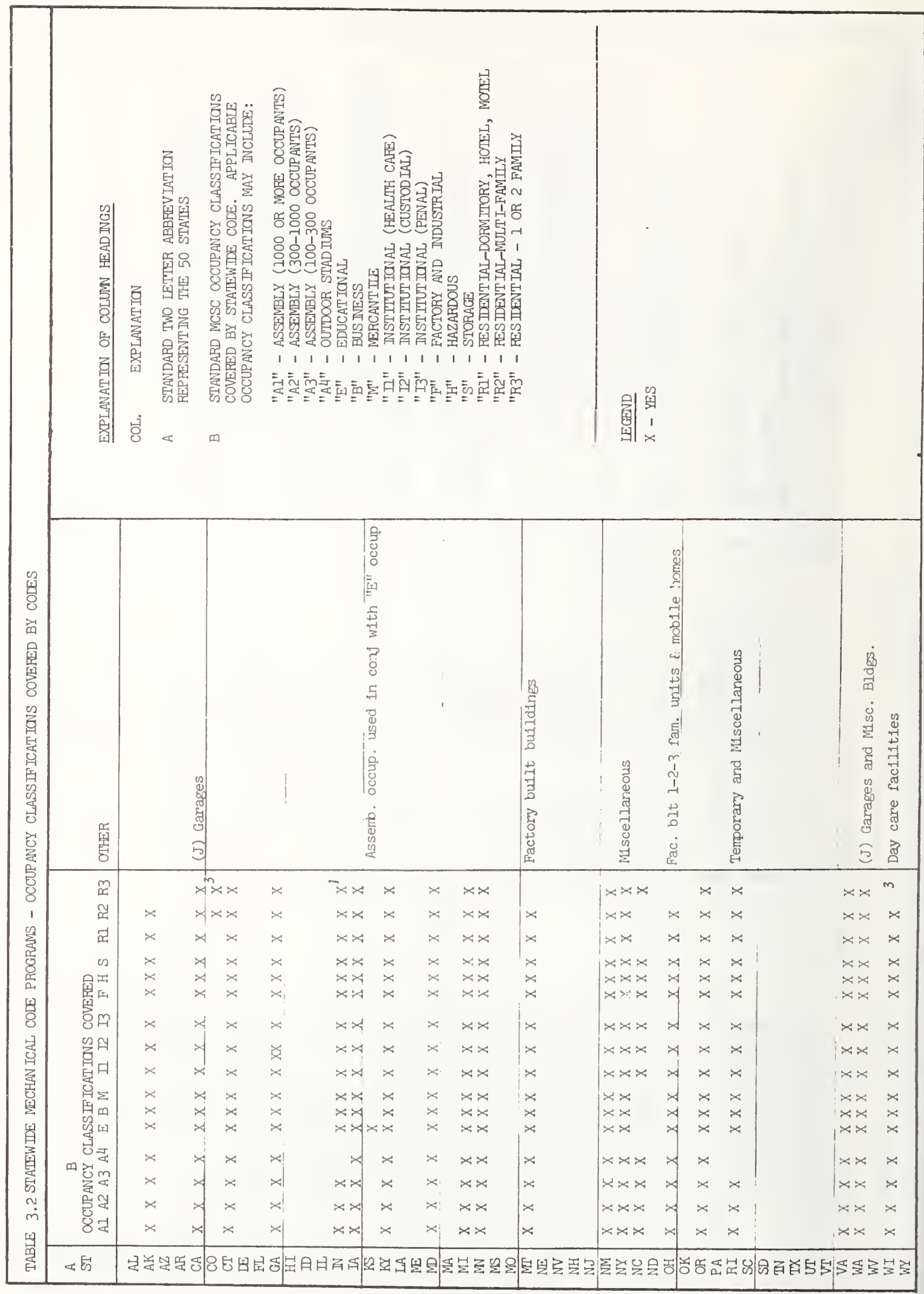




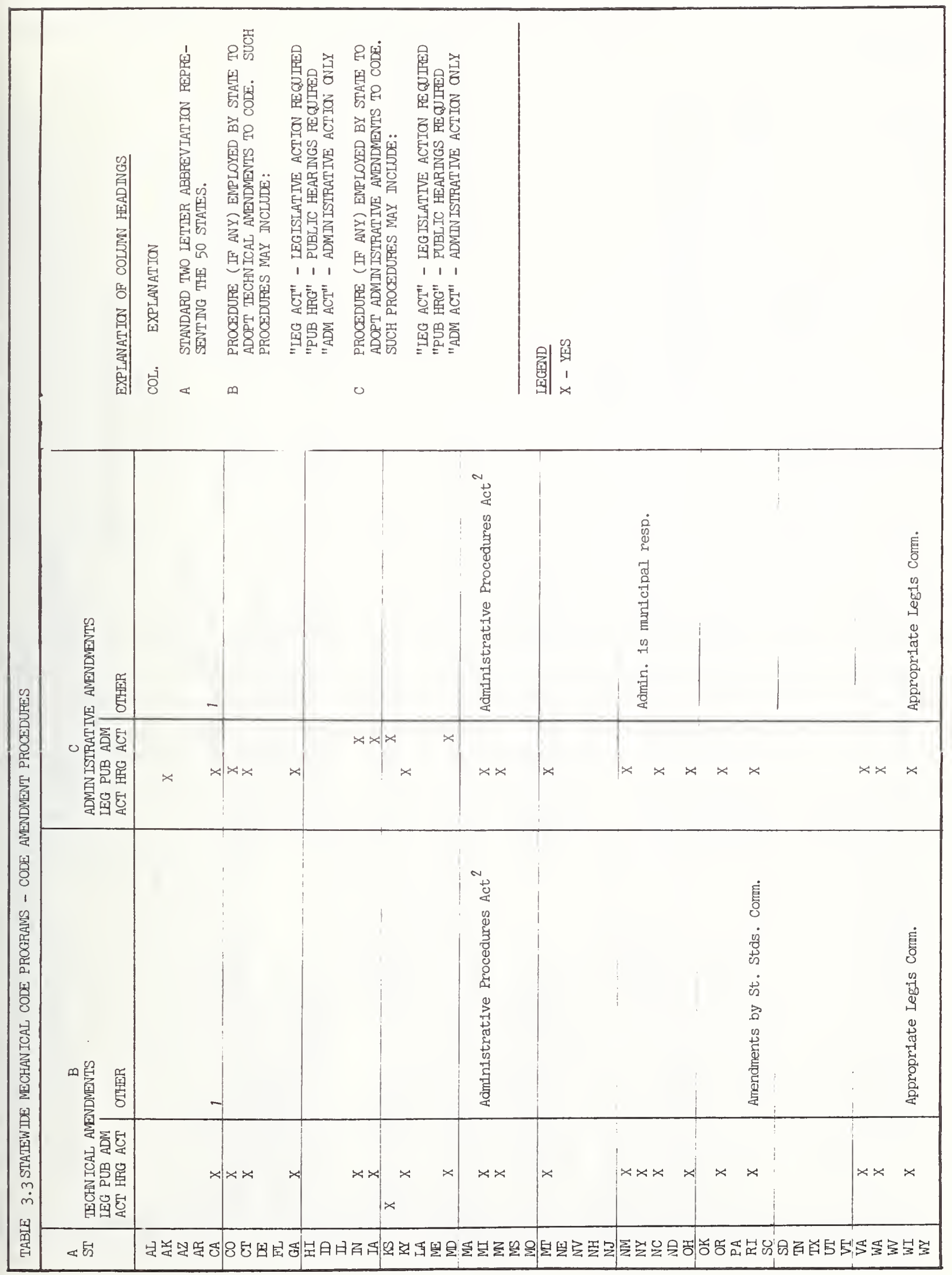




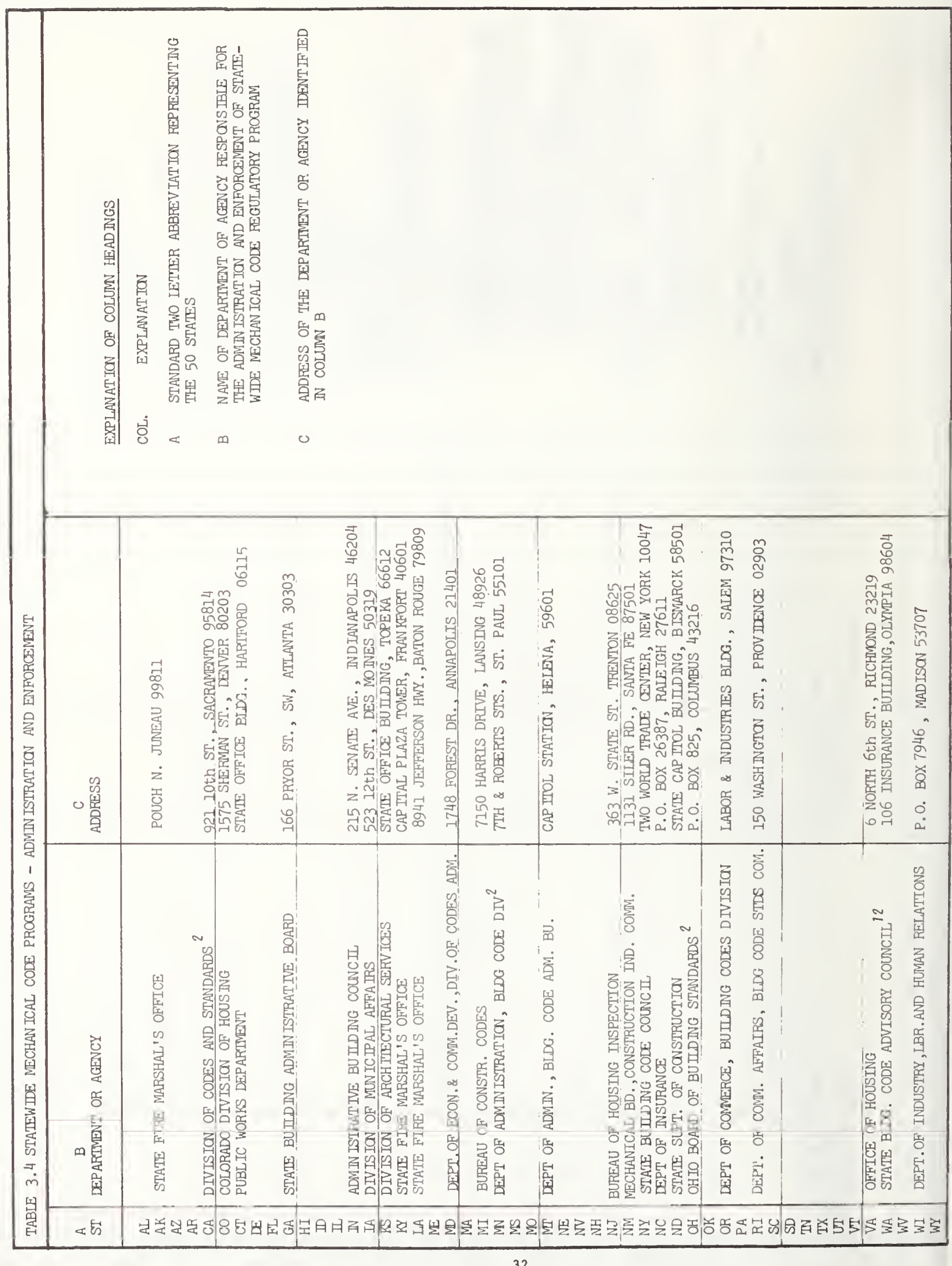




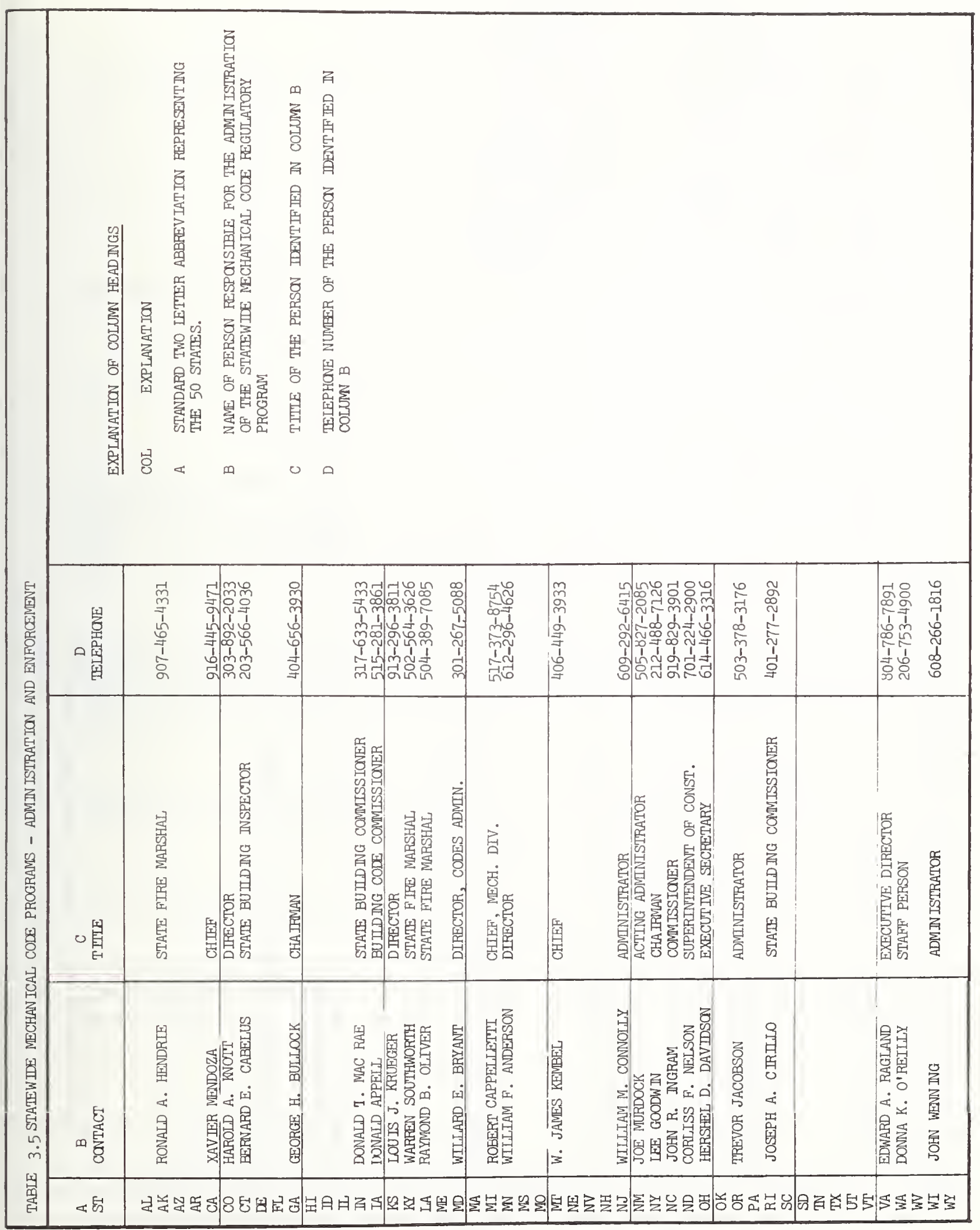




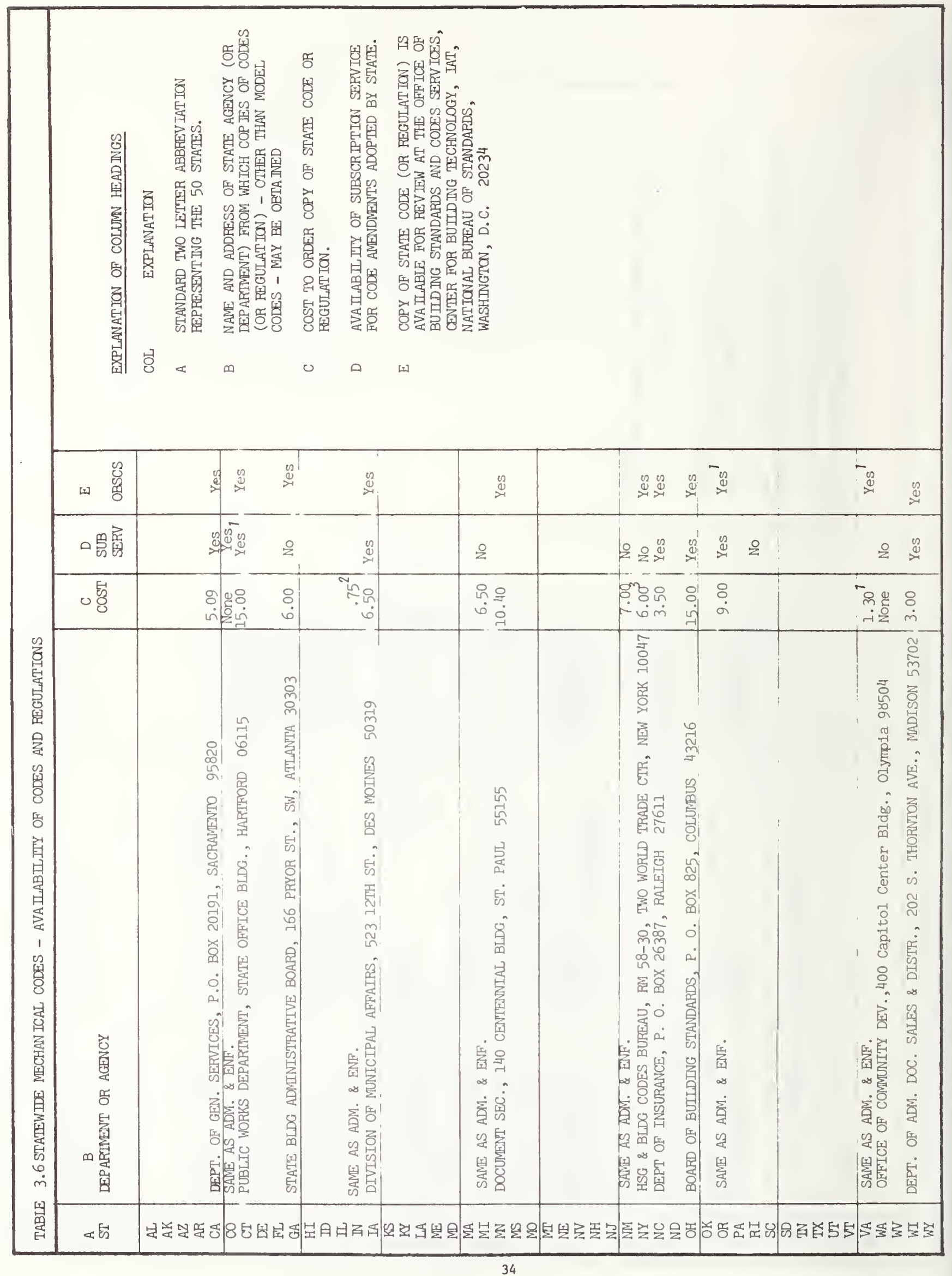


TABIE 3 STATEWDE MECHAN ICAL CODE PROGRAMS

NOIES, GENERAL, REMARKS

ALABAMA

1. All state funded construction must comply with the Standard Mechanical Code (SBCC).

ALASKA

ARIZONA

1. The Uniform Mechancial Code is optionally adopted by $75 \%$ of municipalities. ARKANSAS

\section{CALIFORN IA}

1. Adoption by Commission of Housing and Cormunity Development for dwelling occupanices.

2. In other than residential occupanices, codes are established by the State agency directly affected.

\section{COLORADO}

1. Otherwise known as the "Colorado-Housing Act of 1970."

2. Mandatory in those areas where building codes are not otherwise enforced.

3. "Factory-Built Housing Construction Code" applies to all factory-built residential structures and components.

CONNECTICUT

1. Amendments are provided to all holders of the code.

$$
\text { DELAWARE }
$$

\section{FLORIDA}

1. The Mechanical Code will be part of the Statewide Building Code when it is adopted.

GEORGIA

HAWAII 
TABIE 3 STATEWIDE MECHAN ICAL, CODE PROGRAMS (continued)

TDAHO

IILINOIS

INDIANA

1. One- and Two- Family Dwelling Code applies.

2. Indiana Amendment Booklet to UMC is $\$ .75$.

IOWA

1. Mandatory for state-owned buildings and factory-built structures.

2. Seven cities and one county have adopted the State Building Code.

3. Section 104 (b) of the Administration Section of the Iowa State Building Code.

\section{KANSAS}

1. Enforcement by State Fire Marshal's Of'fice, Floyd Dibberm, State Fire Marshal, 211 West Seventh Street, Topeka, 66603. (Phone: (913) 296-3401).

KENTUCKY

1. Codes of National Fire Protection Association.

\section{LOUISIANA}

1. Compliance with Life Safety Code (NFPA 101) and Section 518 - Special Provisions for High Rise of Chapter IV of the 1974 Amendments to the 1973 Standard Building Code required by the Fire Marshal Act. Rules and regulations to be promulgated by the Fire Marshal.

MAINE

\section{MARYLAND}

1. Code is mandatory for industrialized construction and where the Model Performance Code applies. Adoption of the Model Performance Code is voluntary. 
TABLE 3 STATEWIDE MECHAN ICAL CODE PROGRAMS (continued)

\section{MICHIGAN}

1. Jurisdictions may exempt themselves from the Act and Code and select other nationally recognized model codes.

2. Act 306, PA 1969 as amended.

\section{MINNESOTA}

1. Jurisdictional exceptions: farm buildings, agricultural buildings, municipalities not having standards as of July I, 1972.

2. Enforcement is responsibility of municipalities.

\section{MISSISSIPP I}

MISSOURI

MONTANA

1. Also use the One- and Two- Family Dwelling Code.

NEBRASKA

1. Some municipalities have adopted the Uniform Mechanical Code.

NEVADA

NEW HAMPSHIRE

NEW JERSEY

1. Statewide building code legislation has passed (PL 1975, C. 217) and various subcodes are under consideration. Codes will be adopted without amendment by the State.

NEW MEXICO

NEW YORK

1. Fifty-four cities, 311 villages and 277 towns have adopted State code.

2. Part 5, Equipment Requirements of "General Building Construction."

3. $\$ 6.00$ for all four books of the State Building Construction Code. 
TABLE 3 STALEWIDE MECHAN ICAL CODE PROGRAMS (continued)

NORTH CAROLINA

NORTH DAKOTA

OHIO

1. Chapters BB-45 and BB-47, Ohio Building code.

2. Enforcement is by the Divisions of Factory and Building Inspection, Department of Industrial Relations, P.0. Box 825, Columbus, 43216. Jerald Bruce is Chief, (Phone: (614) 466-6632).

OKLAHOMA

OREGON

1. Oregon rules and amendments.

PENNSYLVAN IA

RHODE ISLAND

1. The One- and Two- Family Dwelling Code is also used.

SOUTH CAROLINA

SOUTH DAKOTA

TENNESSEE

TEXAS

UTAH

VERMONT 
TABIE 3 STATEWIDE MECHAN ICAL CODE PROGRAMS (continued)

VIRG IN IA

1. Virginia Supplement.

WASHINGTON

1. c/o Office of Community Development.

2. Administration and enforcement is the responsibility of the local jurisdiction.

WEST VIRGINIA

1. The National Building Code (1967 Edition) has been promulgated by the State Fire Marshal to regulate fire safety aspects of buildings.

\section{WISCONSIN}

1. Also Chap. Ind. 20 - Dust, Fumes, Vapors and Gases; Chap. Ind. 21 Spray Coatings; Chap. Ind. 7 - Cleaning and Dying; Chap. Ind. 8 Flammable and Combustible Liquids; Chap. Ind. 9 - Liquefied Petroleum Gases.

2. Local ordinances cannot be in conflict, otherwise, State can overmule.

3. Legislation providing for a Statewide code for One- and Two- Family Dwellings passed in 1976. Code is under consideration.

WYOMING 


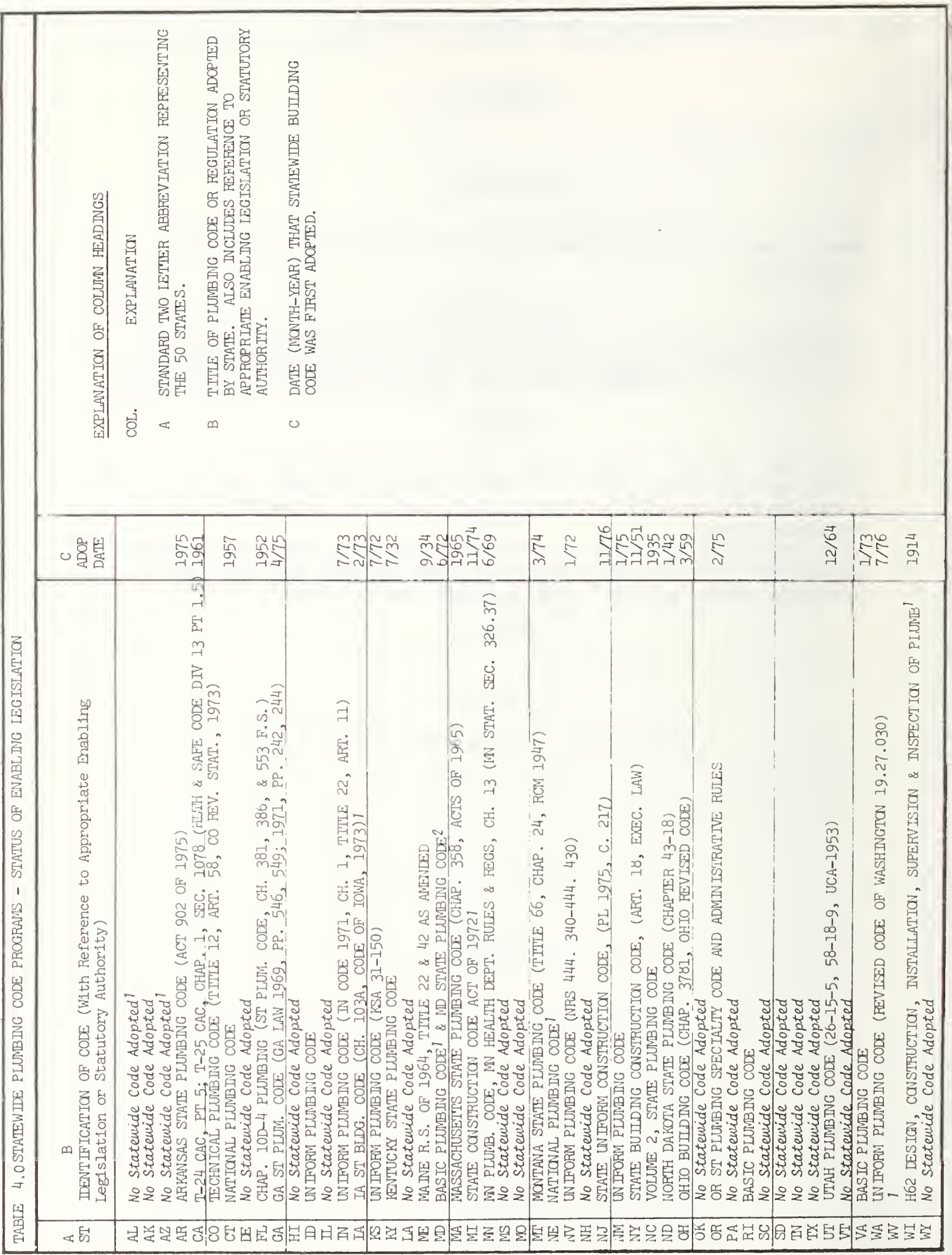




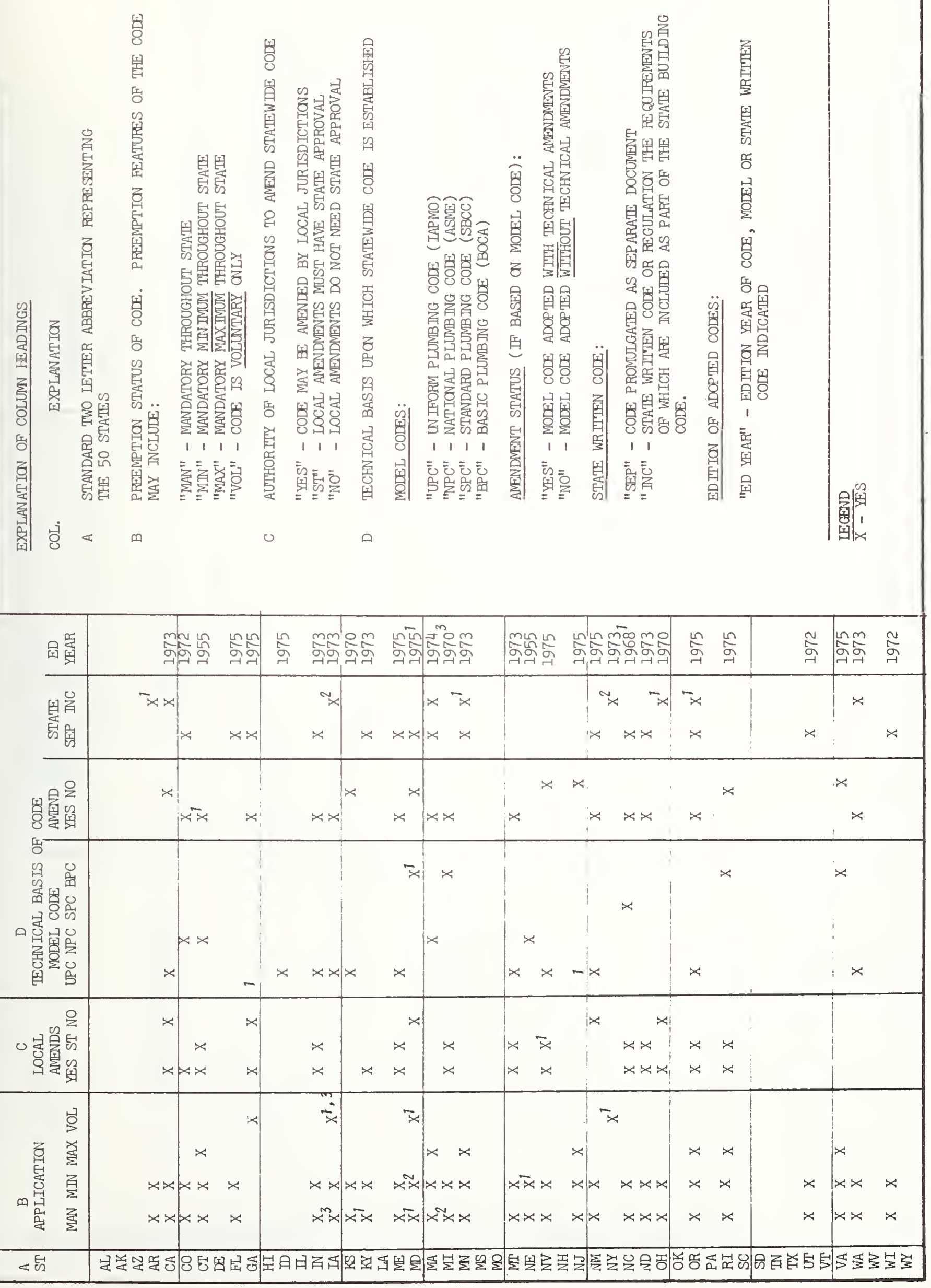




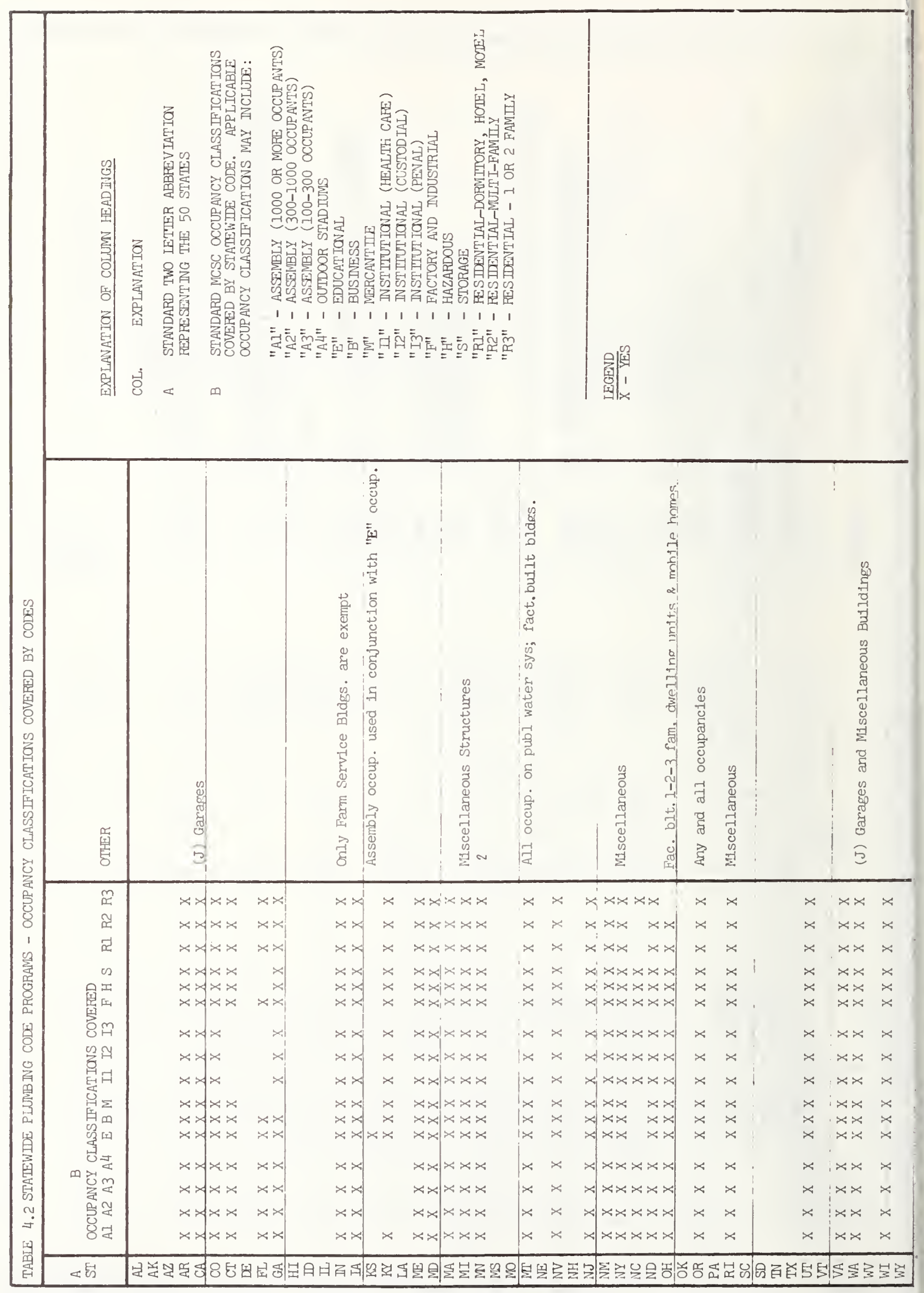




\begin{tabular}{|c|c|c|c|c|c|c|c|c|c|c|c|c|c|c|c|c|}
\hline & 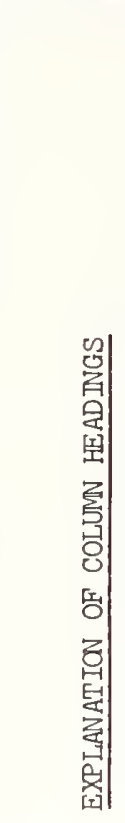 & 总 & 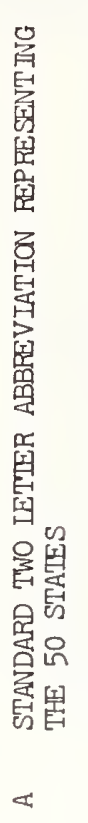 & 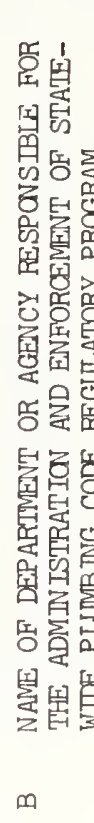 & & 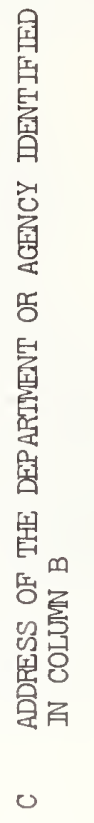 & & & & & & & & & & \\
\hline 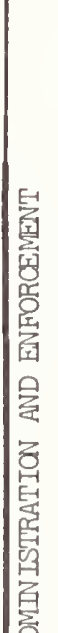 & 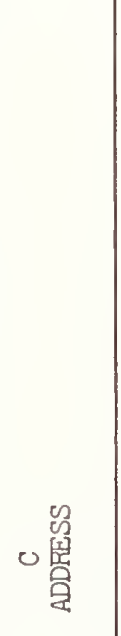 & & 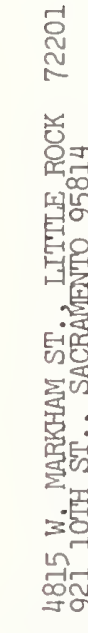 & 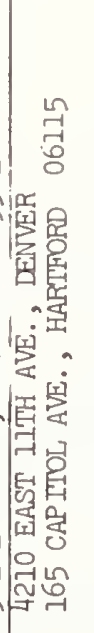 & 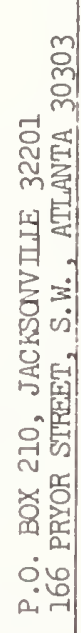 & & 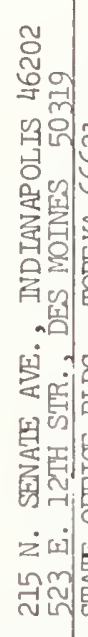 & 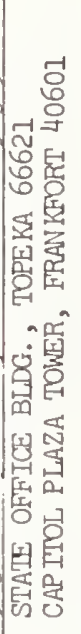 & 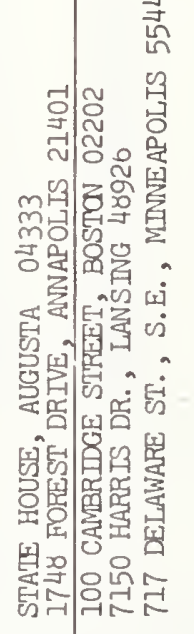 & 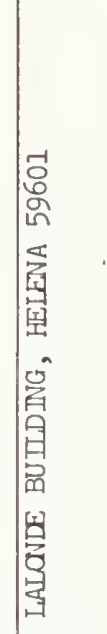 & 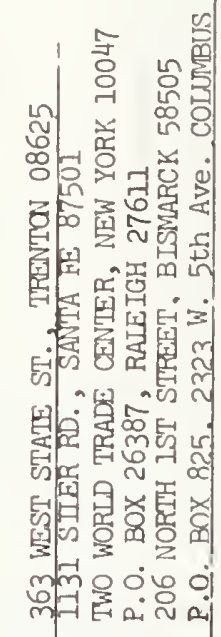 & 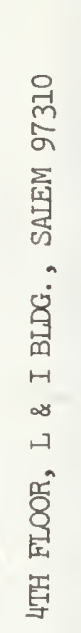 & 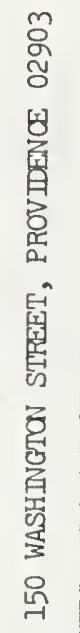 & 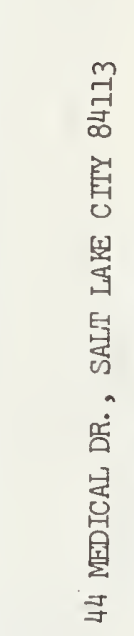 & 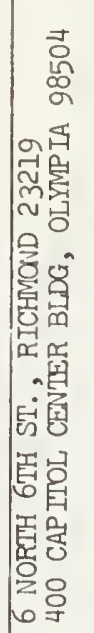 & 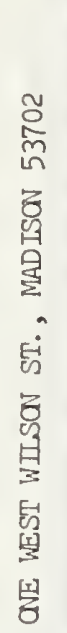 \\
\hline 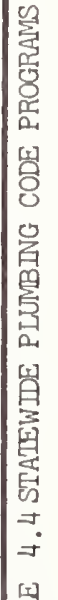 & 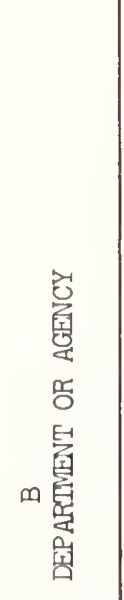 & & 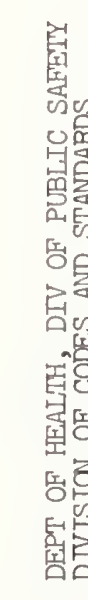 & 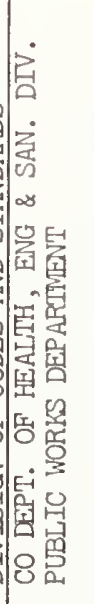 & 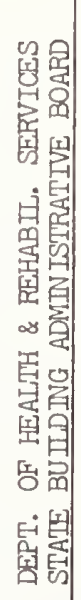 & & 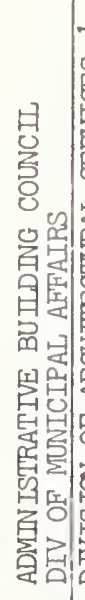 & 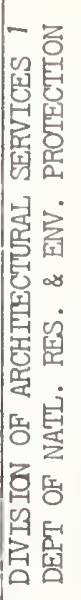 & 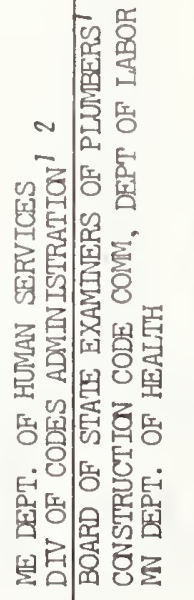 & 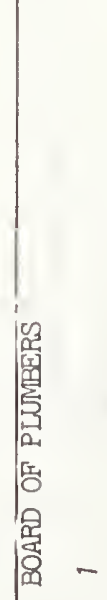 & 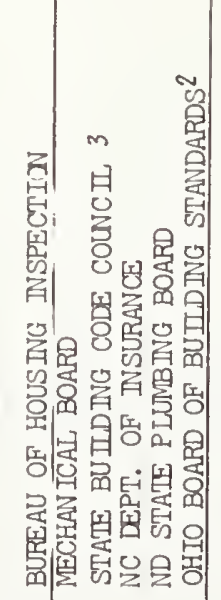 & 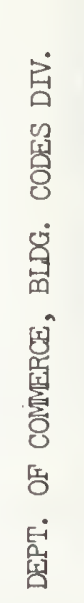 & 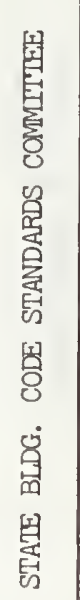 & 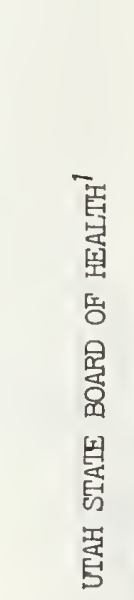 & 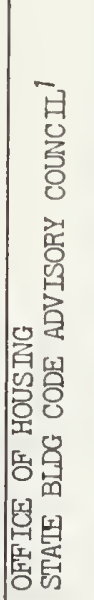 & 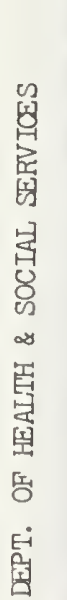 \\
\hline है & 《昆 & 是 & 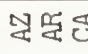 & 86 & 뗘 & 年月 & S! & 102 & 일올볼 & 息䀵 & 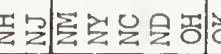 & b㔯匹 & 넌 & 百旨白具 & \{ & 봉농 \\
\hline
\end{tabular}




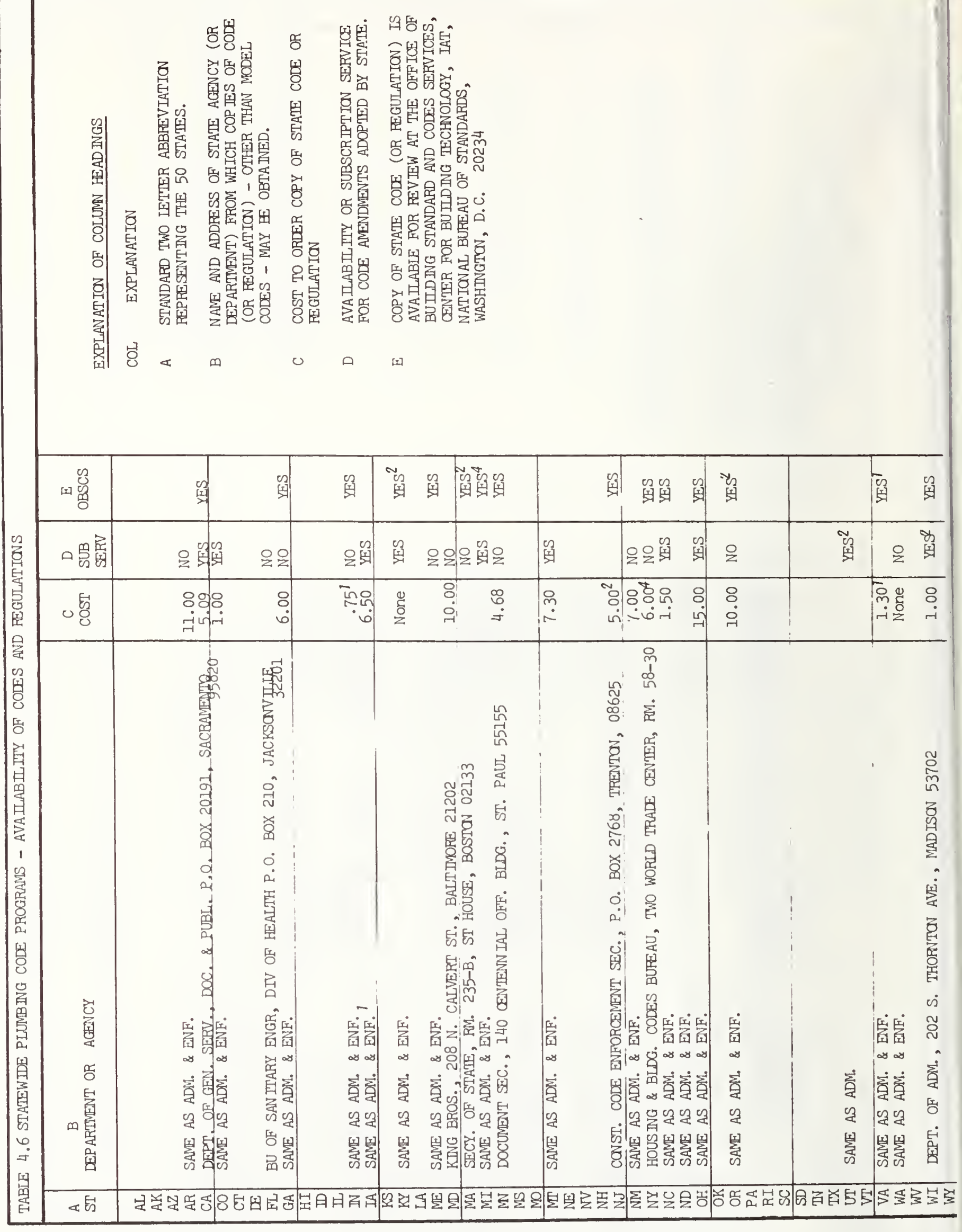


TABIE 4 STATEWIDE PLUMBING CODE PROGRAMS

NOTES, GENERAL REMARKS

ALABAMA

1. All State funded construction mist comply with the Standard Plumbing Code (SBCC).

ALASKA

ARIZONA

1. $75 \%$ of the municipalities have adopted the Uniform Plumbing Code.

ARKANSAS

1. Arkansas State Plumbing Law.

CALIFORN IA

1. Codes established by Department of Housing and Community Development for dwelling occupancies. For other occupancies, codes are established and enforced by the state Agency directly effected.

COLORADO

CONNECTICUT

1. As amended by the Connecticut Basic Building Code.

DELAWARE

FLORIDA

GEORGIA

1. 1975 National Standard Plumbing Code (published by National Association of Plumbing, Heating and Cooling Contractors and American Association of Plumbing Engineers).

HAWAII 
TABLE 4 STATEWIDE PLUNBING CODE PROGRAMS (continued)

IDAHO

IILINOIS

INDIANA

1. Indiana Amendment Booklet to UPC is $\$ .75$.

IOWA

1. State Plumbing Code, Chapter 135, Code of Iowa, applies where Iowa State Building Code does not apply. Admin. Agency: State Health Dept., Norman Pawlewski, Commissioner.

2. Sect. 104 (c), of the Admin. Section of the Iowa State Building Code.

3. Code is mandatory for all State-owned buildings and factory built structures. Cities over 6,000 shall adopt State Plumbing Code if they have not adopted the State Building code.

4. State Plumbing Code from Dept. of Health, Lucas State Office Bullding, Des Molnes, 50319.

\section{KANSAS}

1. Enforcement Agency: State Fire Marshal's Office, Floyd Dibbern, State Fire Marshal, 211 West Seventh St., Topeka, 66603. (Phone: (913) 296-3401).

\section{KENTUCKY}

1. Exceptions: City of Louisville and Covington.

2. 1972 Edition.

\section{LOUISIANA}

MAINE

\section{MARYLLAND}

1. Basic Plumbing Code for Industrialized Buildings (Art. 41, Section 226, EE-1 to EE-6) and the Model Performance Codes Art 4l, Section 257J. For industrialized buildings it is mandatory; for use with model performance code it is voluntary.

2. Maryland State Plumbing Code Art. 4I, Section 9 of annotated Code of Maryland (1971 Replacement Volume). This is a minimum code which applies to a jurisdiction which does not have its equal or better code. Promulgated by the Dept. of Licensing and Regulation, One South Calvert St., Baltimore, 21202, (Phone: (301) 383-2445). 
TABIE 't STAIEWIDE PLUMIBING CODE PROGRAMG; (continued)

\section{MASSACHUSETTS}

1. Enforced by local plumbing inspector.

2. 1971 addition.

\section{MICHIGAN}

1. P.A. 1972, No. 230, BOCA Basic Plumbing Code, 1970 Edition, including accumulative supplement dated 1973 with exceptions.

2. Cities, townships or villages may adopt a nationally recognized code all amendments must be reviewed and approved by Construction Code Commission.

3. 1973 accumulative supplements.

4. Michigan rules and amendments to the Basic Plumbing Code.

\section{MINNESOTA}

1. Adopted by reference in State Building Code.

2. Occupancy classification not specified in the code.

\section{MISSISSIPPI}

\section{MISSOURI}

MONTANA

\section{NEBRASKA}

1. Cities may adopt another code as long as it is equal to or exceeds the 1955 National Plumbing Code.

\section{NEVADA}

1. Law provides for enforcement by Northern and Southern Regional plumbing boards which also must approve changes desired by local jurisdictions.

NEW HAMPSHIRE

\section{NEW JERSEY}

1. National Standard Plumbing Code/1975 (published by the National Association of Plumbing-Heating-Cooling Contractors, Inc./The American Society of Plumbing Engineers.

2. New Jersey Uniform Construction Code Regulations relate to Administration and Enforcement and Building, Plumbing, Electrical and Fire Protection Subcodes. 
TABIE 4 STATEWIDE PLUMBING CODE PROGRAMS (contInued)

NEW MEXICO

NEW YORK

1. 54 citles, 277 towns and 311 villages have adopted the code.

2. Part 5, Equipment Requirements, of "General Building Construction."

3. Enforcement is responsibility of municipalities.

4. $\$ 6.00$ for all four books of the State Bullding Construction Code.

NORTH CAROLINA

1. With 1974 supplement.

NORTH DAKOTA

OHIO

1. Chapter BB-51, Oh1o Bullding Code.

2. Enforcement Agency: Plumbing Inspection Unit, Dept. of Health, Richard McClusky, Chief, 408 East Town Street, Room 1415, Columbus, 43215. (Phone: (614) 466-4746.)

OKLAHOMA

OREGON

1. Senate Bill No. 73 , by Statute, becomes part of State Bullding Code.

2. Oregon rules and amendments.

PENNSYLVANIA

RHODE ISLAND

SOUTH CAROLINA

SOUTH DAKOTA

TENNESSEE 
TABLE 4 STATEWIDE PLUMBING CODE PROGRAMS (continued)

\title{
TEXAS
}

\section{UTAH}

1. Enforcement Agency: Dept. of Registration, Floy W. McGinn, Head, 330 E. 4th South, Salt Lake C1ty. (Phone: (801) 533-5711).

2. Obtainable at Department Office.

$$
\text { VERMONT }
$$

\section{VIRGINIA}

1. Virginia Supplement.

$$
\text { WASHINGTON }
$$

1. c/o Office of Community Development.

$$
\text { WEST VIRGINIA }
$$

1. The Plumbing Code would only apply where N.F.P.A. and the National Building Code would Indicate.

\section{WISCONSIN}

1. H-61 Apprenticeship and Licensing of Plumbers. H-64 Certification of Soll Testers. H-65 Subdivisions not served by public sewers.

2. Update service $\$ 1.00$.

\author{
WYOMING
}




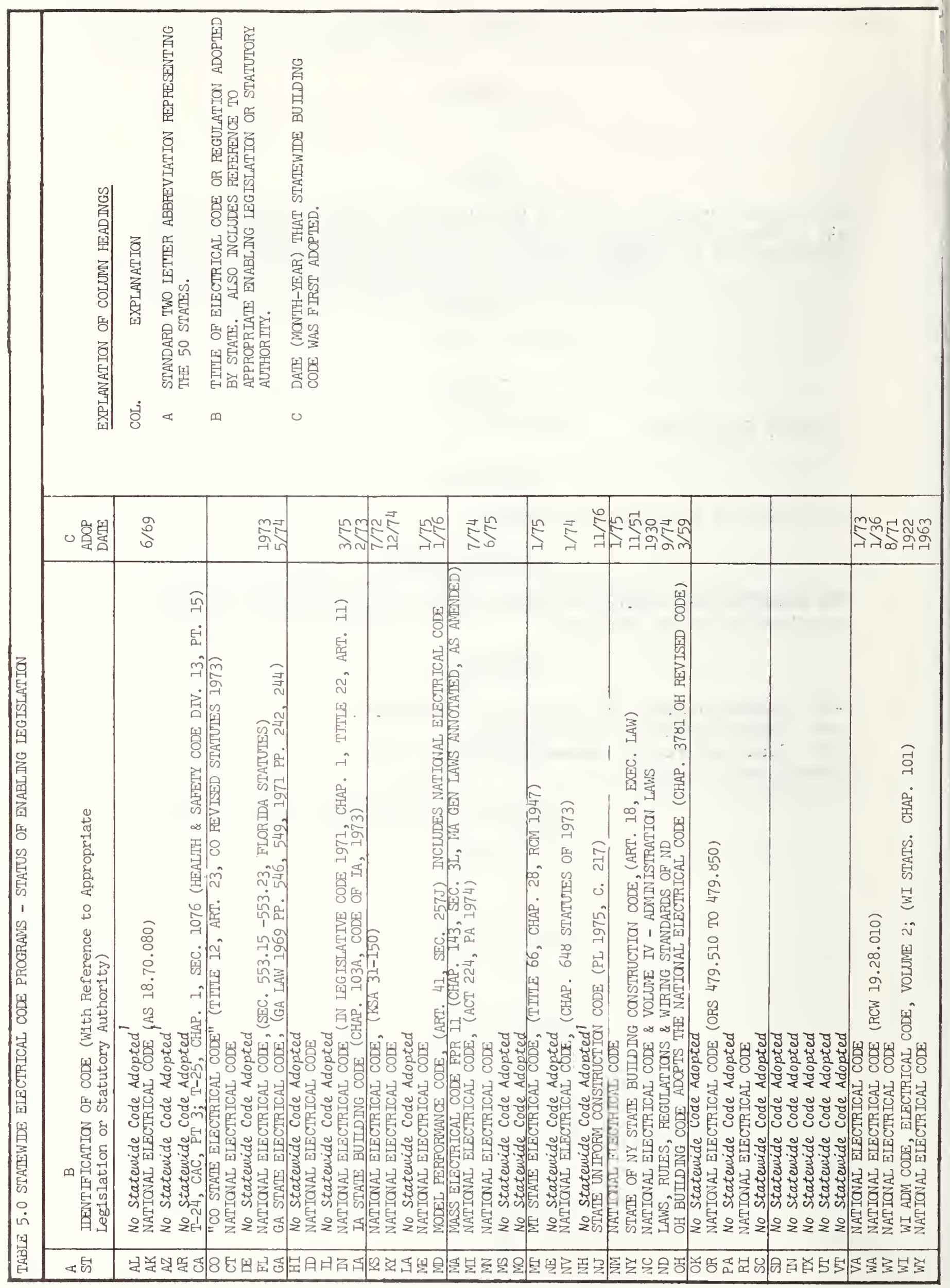




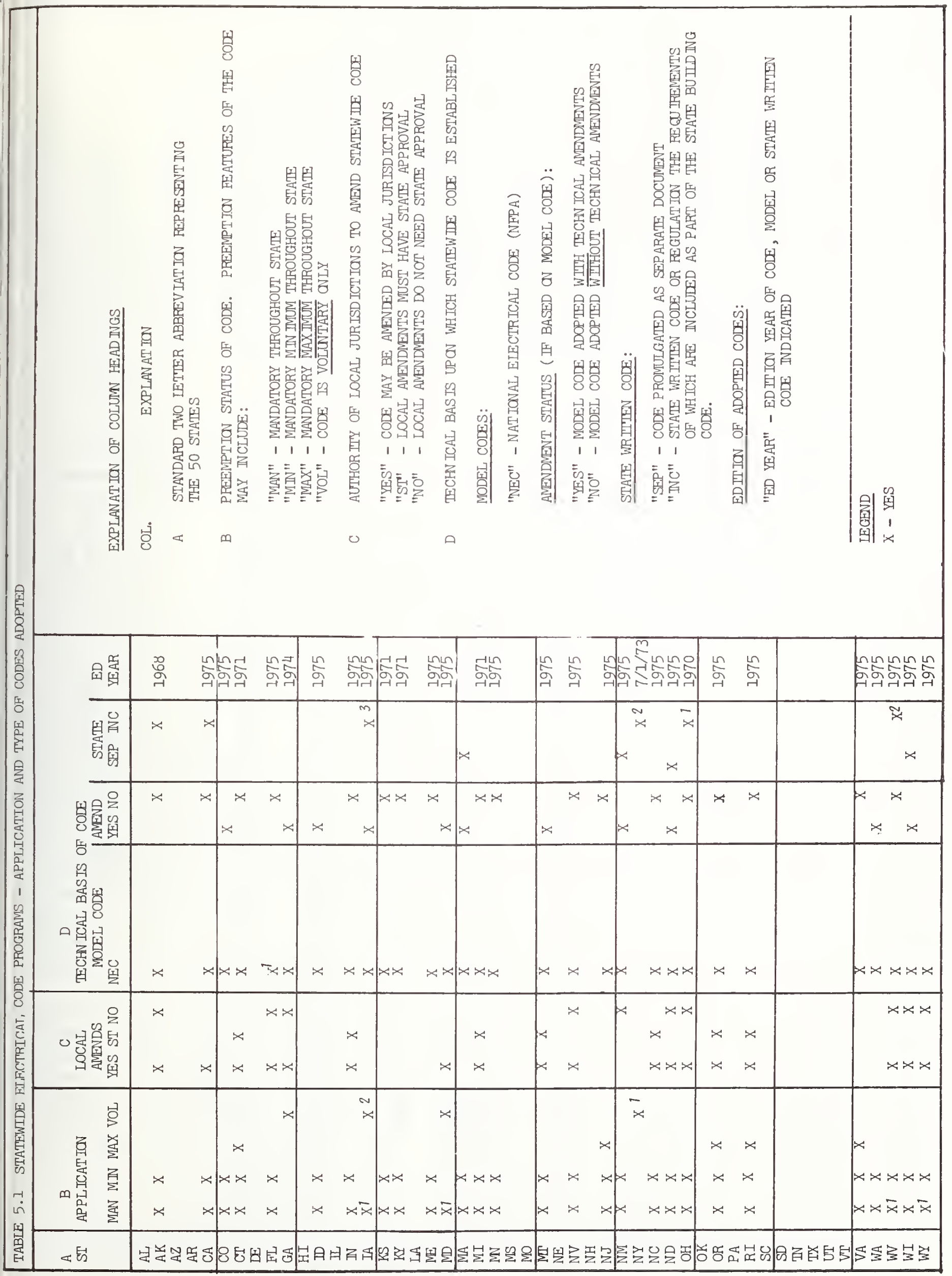




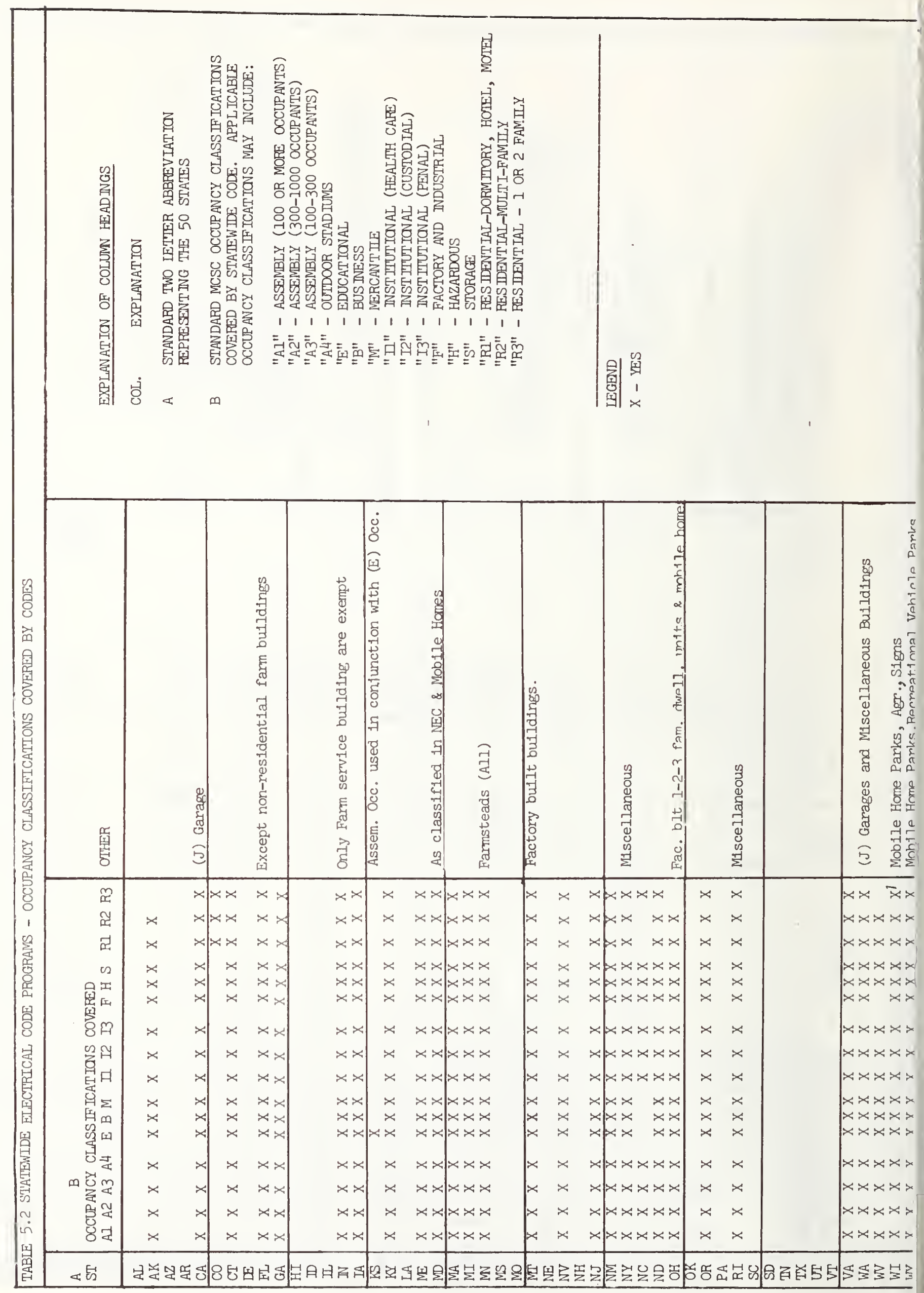




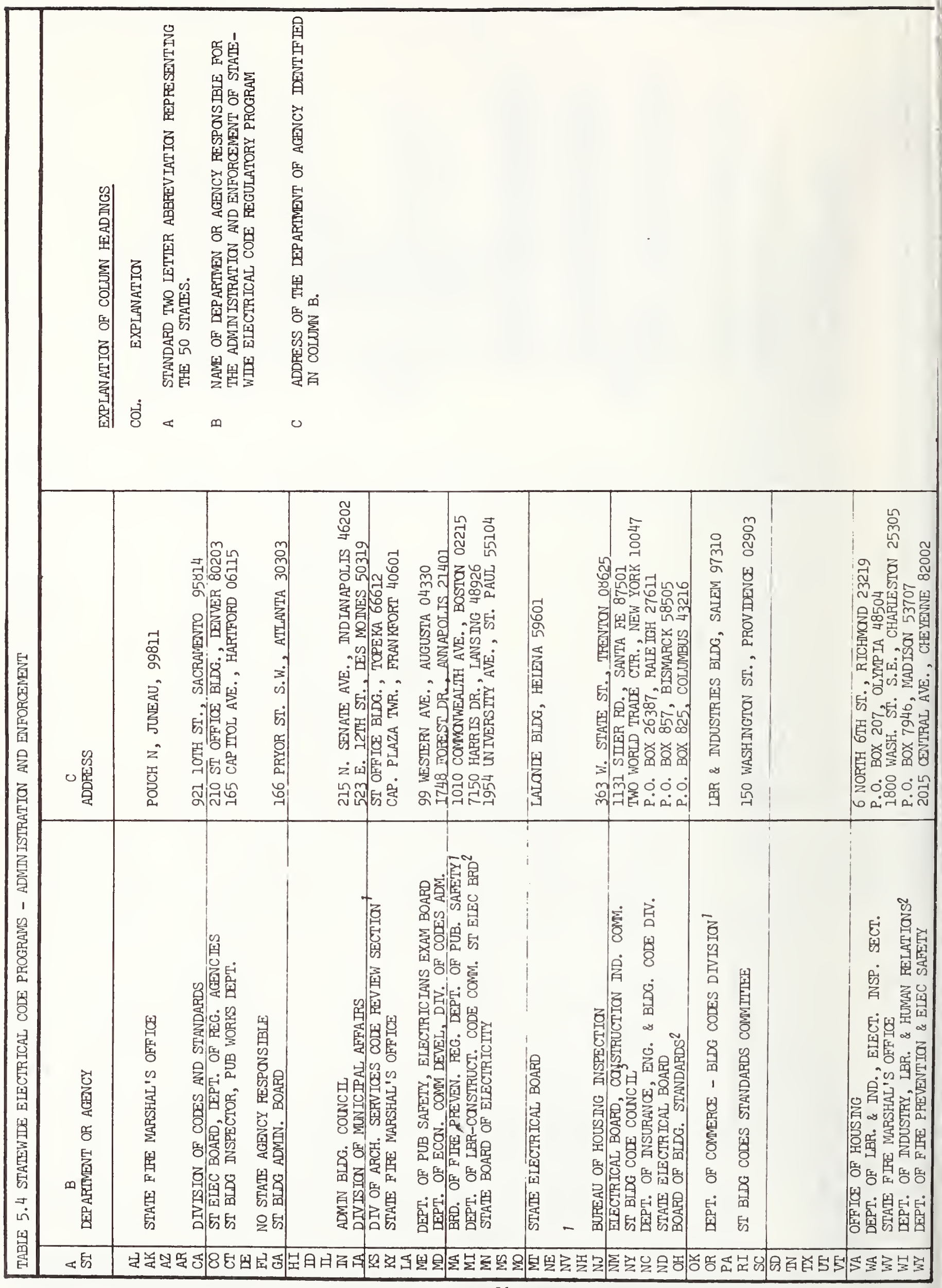




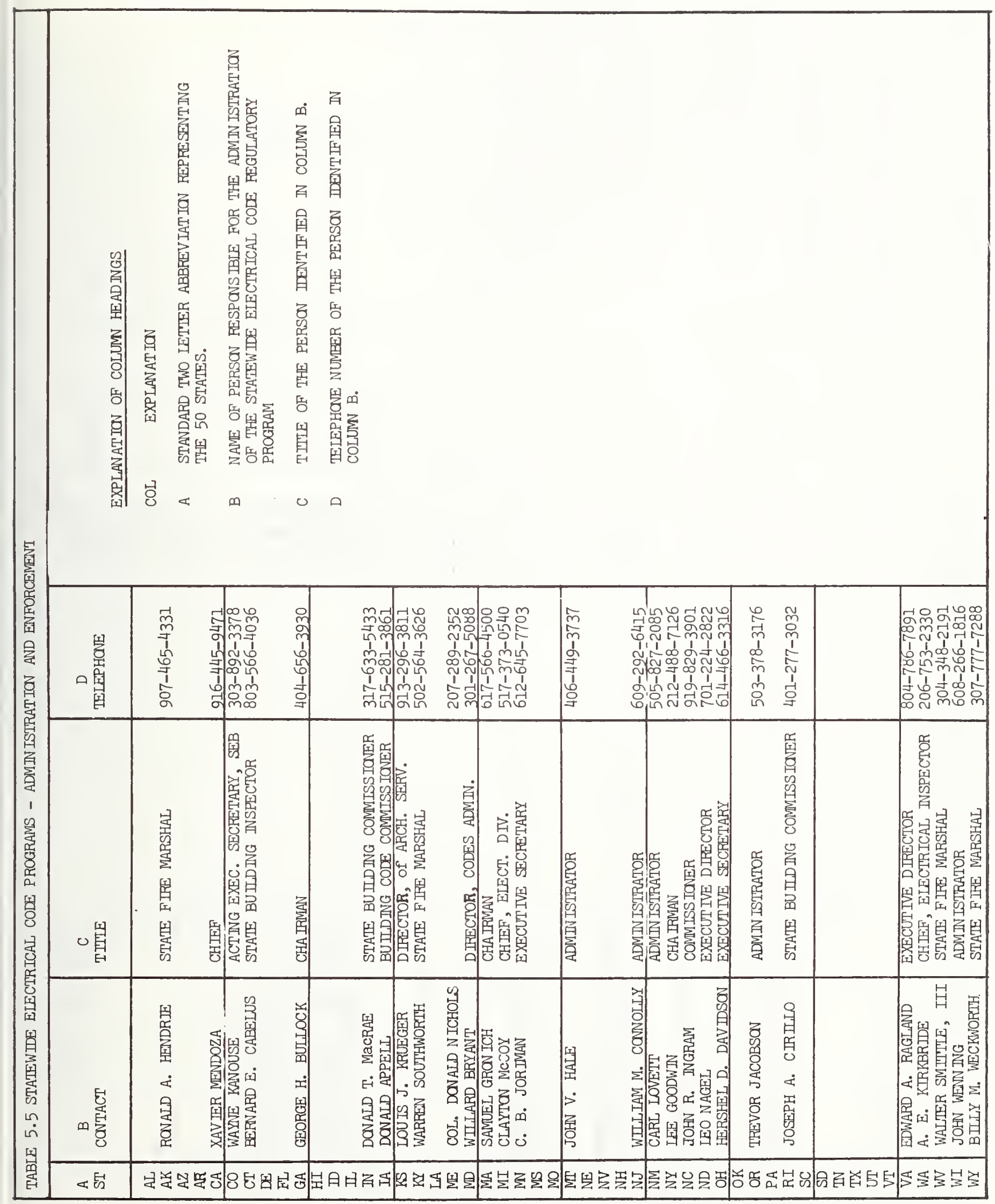




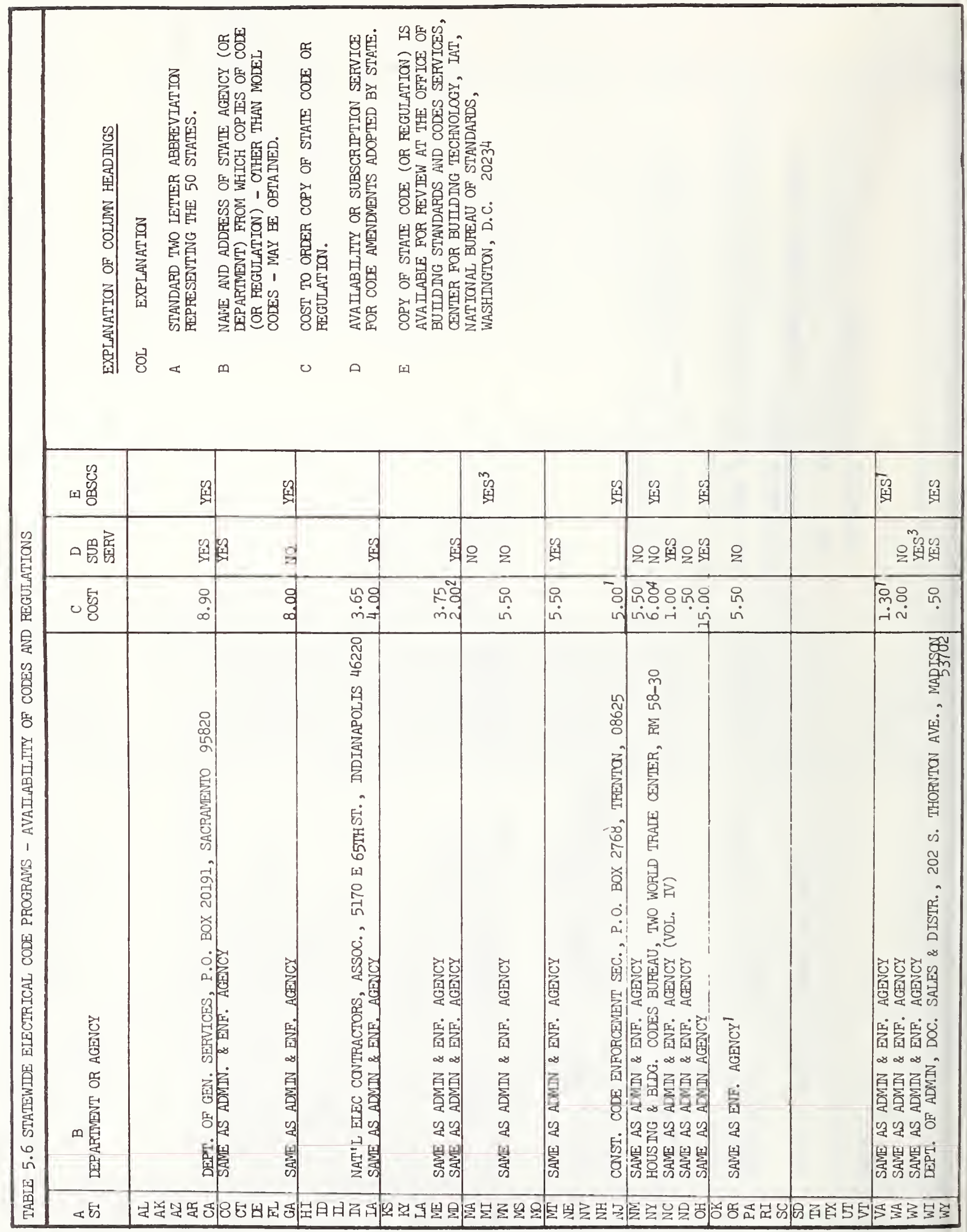


TABLE 5 STATEWDE ELECTRICAL CODE PROGRAMS

NOTES, GENERAL REMARKS

ALABAMA

1. All state funded construction must comply with the National Electrical Code (NFPA 70).

ALASKA

ARIZONA

1. NEC is optionally adopted by $75 \%$ of municipalities.

ARKANSAS

CALIFORNIA

1. Codes for dwelling occupancies shown are established by the Department of Community Development. Codes for other occupancies established by the State agency directly affected.

COLORADO

CONNECTICUT

DELAWARE

FLORIDA

1. In addition a number of other NFPA, UL and State rules and regulations are referenced.

GEORGIA

HAWAII

1

IDAHO 
TABIE 5 STATEWIDE EIECTRICAL CODE PROGRAMS (contInued)

\section{IILINOIS}

INDIANA

IOWA

1. Mandatory for State-owned buildings and factory built structures.

2. Seven cities and one county have adopted the state bullding code.

3. Section 104 (d) of Administration section of the Iowa State Building code.

KANSAS

1. Enforcement by State Fire Marshal's Office, Floyd Dibbern, State Fire Marshal, 211 West Seventh Street, Topeka, 66603. (Phone: (913) 296-3401).

KENTUCKY

LOUISIANA

MAINE

MARYLAND

1. Code is mandatory for industrialized construction and where performance code applies.

2. Maryland Regulations - Codes Administration.

MASSACHUSETTS

1. The Board of State Examiners of Electricians, 100 Cambridge Street, Boston, 02202 is responsible for code enforcement. (Phone: (617) $72(-3050)$.

\section{MICHIGAN}

1. Future NEC editions may be processed under Act 230, PA 1972 and Act 306, PA 1969.

2. Enforcement by Construction Code Cormission, Robert Hilprecht, Executive Director, 7150 Harris Drive, Lansing, 48926. (Phone: (517) 373-8167).

3. Administrative miles and regulations. 
TABLE 5 STATEWIDE ELECTRICAL CODE PROGRAMS (continued)

MINNESOTA

MISSISSIPP I

MISSOURI

MONTANA

NEBRASKA

NEVADA

1. State enforcement agency not yet established.

NE'W HAMPSHIRE

1. Code may be established at option of each municipality.

NE'W JERSEY

1. New Jersey Uniform Construction Code Regulations relate to Administration \& Enforcement \& Building, Plumbing, Electrical \& Fire Protection Subcodes. NEW MEXICO

NEW YORK

1. Fifty-four cities, 277 towns, 311 villages have adopted the code.

2. Part 5, Equipment Requirements, of "General Building Construction."

3. Enforcement is municipal responsibility.

4. $\$ 6.00$ for all four books of the State Building Construction Code.

NORIH CAROLINA

NORTH DAKOTA 
TABIE 5 STATEWIDE EIECTRICAL CODE PROGRAMS (continued)

\section{OHIO}

1. Chapter BB-49, Ohio Bullding Code.

2. Enforcement is by the Division of Factory and Bullding Inspection, Department of Industrial Relations, P.O. Box 825, Columbus, 43216. Jerald Bruce is Chief, (Phone: (614) 466-6632).

\section{OKLAHOMIA}

\section{OREGON}

1. Enforcement is by the Electrical Section, Department of Commerce, 1400 S.W. Fifth Avenue, Portland, 97201. S1 Hot'fmann is Chief, (Phone: (503) 229-5761).

PENNSYLVAN IA

RHODE ISLAND

SOUTH CAROLINA

SOUTH DAKOTA

TENNESSEE

TEXAS

UTAH

VERMONT

VIRGIN IA

1. Virginia Supplement. 
TABIE 5 STATEWIDE EIECTRICAL CODE PROGRAMS (continued)

\author{
WASHINGTON
}

\title{
WEST VIRGINIA
}

1. Exception: Where cities have adopted same code and have enforcement authority.

2. Adopted and filed as part of Fire Marshal's regulations.

3. Subscription service amendment requests should be addressed to the Secretary of State, Capitol Building, Charleston, 25305.

\section{WISCONSIN}

1. Legislation passed (SB 105, Chapter 404) published June 9, 1976, for a statewide One- and Two- Family Dwelling Code and (SB 106, Chapter 405) for a manufactured building code for dwellings. Legislation provides preemption of local ordinances including electrical code and certification of inspectors. Local municipality has option to administer, Inspect, enforce, set fees and provide remedies and penalties. Otherwise, mandatory contract is required with State agency for inspection. Approximately two year time until program is effective.

2. Utility companies are restricted from making electrical hook up until compliance statement or affidavit is received. Wisconsin Stats. 167.16.

\section{WYOMING}

1. Mines, rallroads, ranches over 40 acres and public utilities are excepted. 


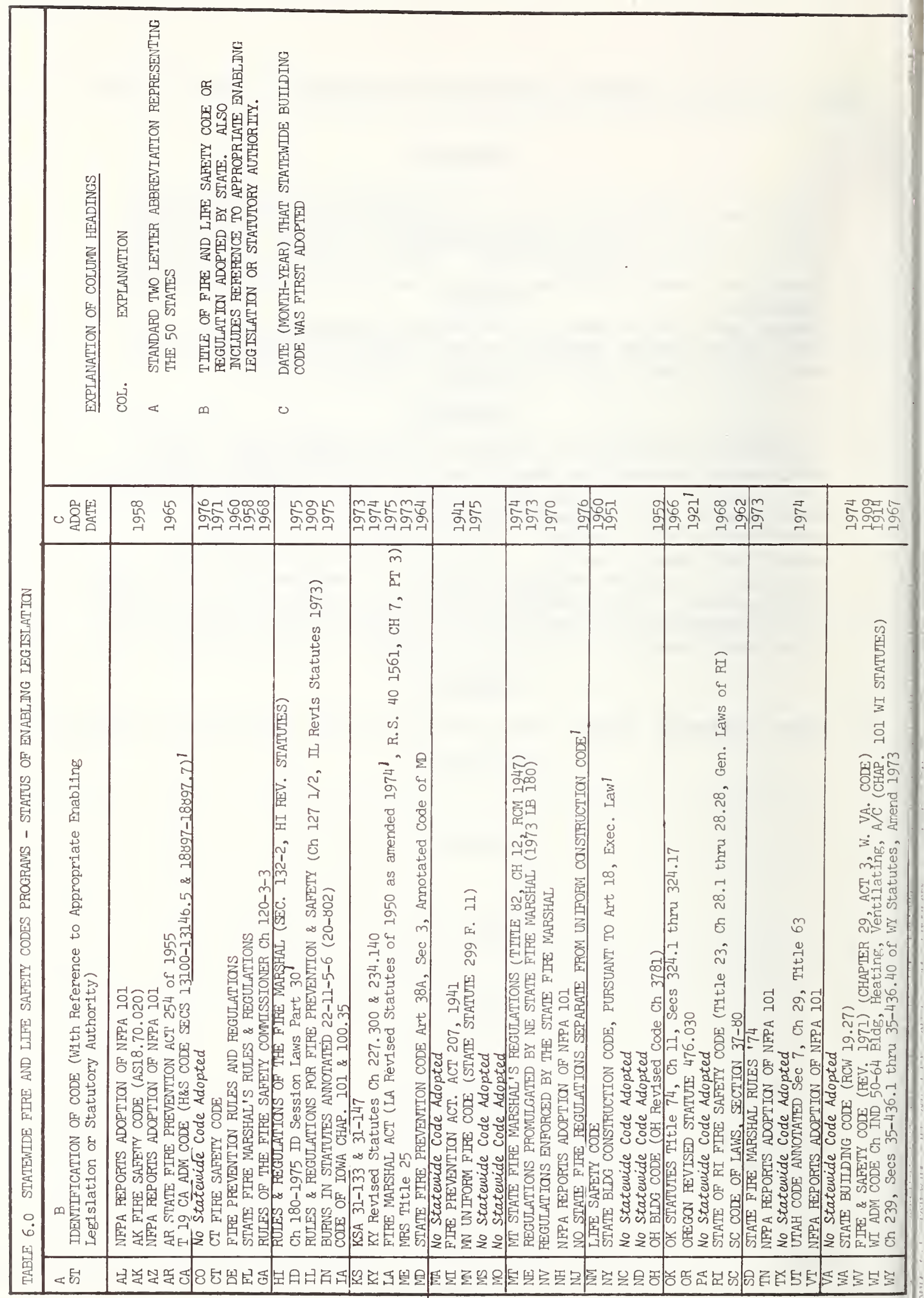



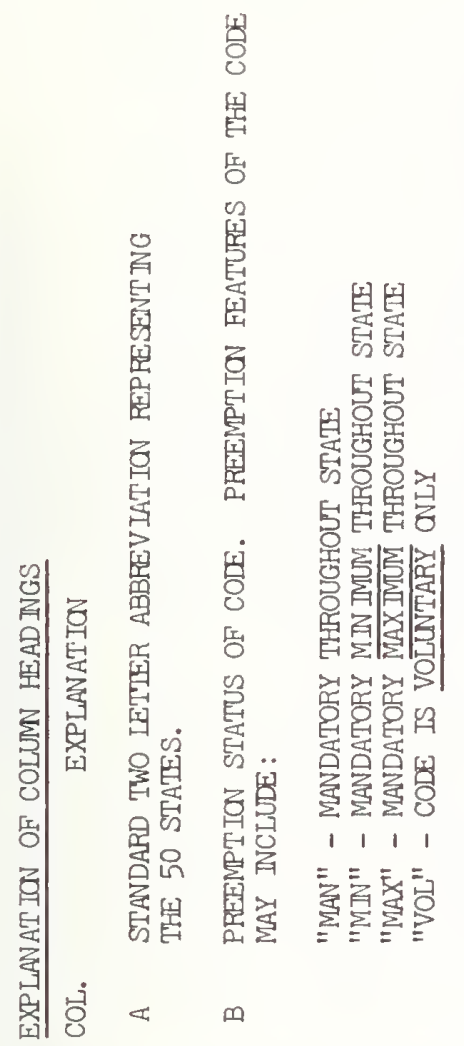

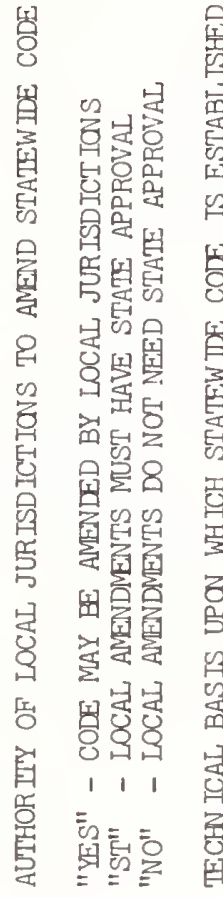

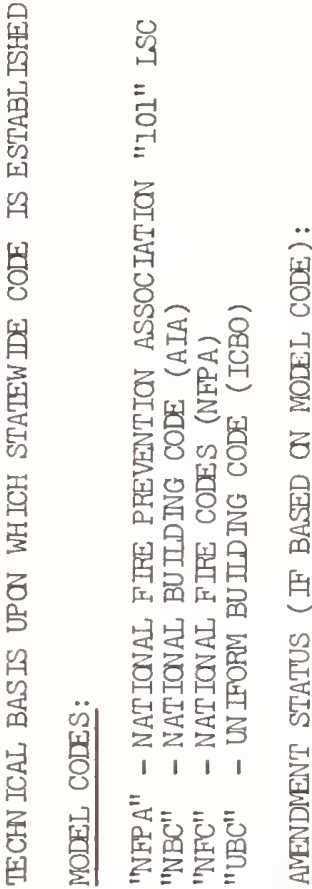

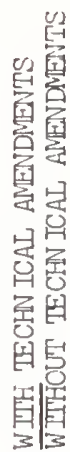

窗

th

息是

窟留

它国

舆昆

窗留留

要留

불불

家识

溗瓷

능

की

시봅

웡을

岁客

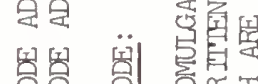

응

譻睤

之

귱ㅎㅇ

일 뚠

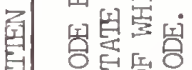

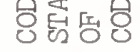

1
$==$

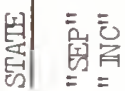

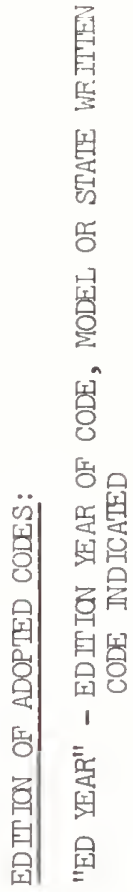

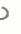

๑

?
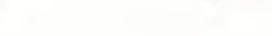

\begin{tabular}{|c|c|c|c|c|c|c|c|c|c|c|c|c|c|}
\hline 吕孚 & 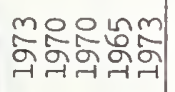 & 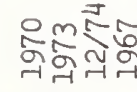 & 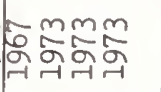 & 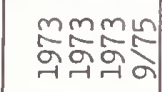 & 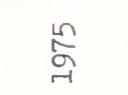 & 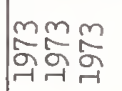 & & $\stackrel{m}{2}$ & & $\begin{array}{l}m m \\
\text { mon } \\
\text { s. }\end{array}$ & 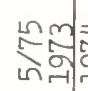 & $\underset{\substack{a\\
}}{n}$ & 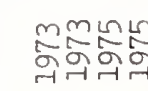 \\
\hline 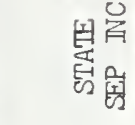 & $x x$ & $x$ & $x \times x$ & $\begin{array}{ll}x & x\end{array}$ & $x x$ & $\rtimes$ & & $x$ & $-x$ & $\begin{array}{l}\rtimes \\
\rtimes\end{array}$ & $\times$ & $x$ & $x \times x$ \\
\hline 四夏唯 & $\begin{array}{l}x \\
\times \quad x\end{array}$ & $x$ & $\rtimes$ & $x^{x} \times x$ & $x$ & $x x$ & $x$ & $x$ & & $x$ & $x$ & $x$ & $x^{x} x$ \\
\hline 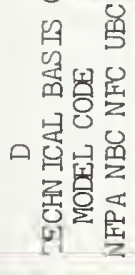 & $\begin{array}{c}x \\
x \\
x \\
x \\
x \times x \times x\end{array}$ & $-x x$ & $\begin{array}{ll}x & x \\
& x- \\
& \\
x & \end{array}$ & $\begin{array}{c}x \\
x \\
x \times x^{2} x x^{x} x\end{array}$ & $\begin{array}{l}\bar{x} \\
x \\
x\end{array}$ & $x \times x$ & & $x$ & & $x^{x}$ & & $x$ & $\begin{array}{c}x \\
x \\
x \\
x\end{array}$ \\
\hline 0 是夏兒 & $\begin{array}{l}x \quad x x \\
x \quad \bar{x} x\end{array}$ & & $\begin{array}{l}x \\
x\end{array}$ & $\begin{array}{l}x x \\
x x \quad x\end{array}$ & $x$ & $\begin{array}{l}\rtimes \\
x\end{array}$ & & 4 & $x$ & $\begin{array}{l}\rtimes \\
\rtimes\end{array}$ & $x, x \mid$ & $\times$ & $\underset{x}{x}$ \\
\hline 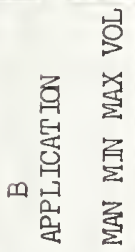 & $\begin{array}{ll}x & x \times \\
x & x x\end{array}$ & $x_{>}$ & $4 \times x$ & $\begin{array}{l}x \times x \times x \\
x \times x \times x\end{array}$ & $\begin{array}{l}x x \\
x x\end{array}$ & $\begin{array}{l}x \rtimes x \\
x \times x\end{array}$ & & $\star x$ & & $x$ & $\begin{array}{l}x x \\
x\end{array}$ & $\begin{array}{l}x \\
x\end{array}$ & $\begin{array}{l}x \not x x \\
x \times x \times\end{array}$ \\
\hline$<\xi$ & 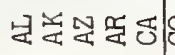 & 马兒留局顿 & 用日台兵 & 话西国貝 & $\sum \sum \sum$ & 专䛼方至 & & 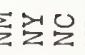 & 罗: & 孚孚 & 证品司 & 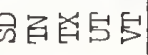 & 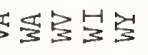 \\
\hline
\end{tabular}




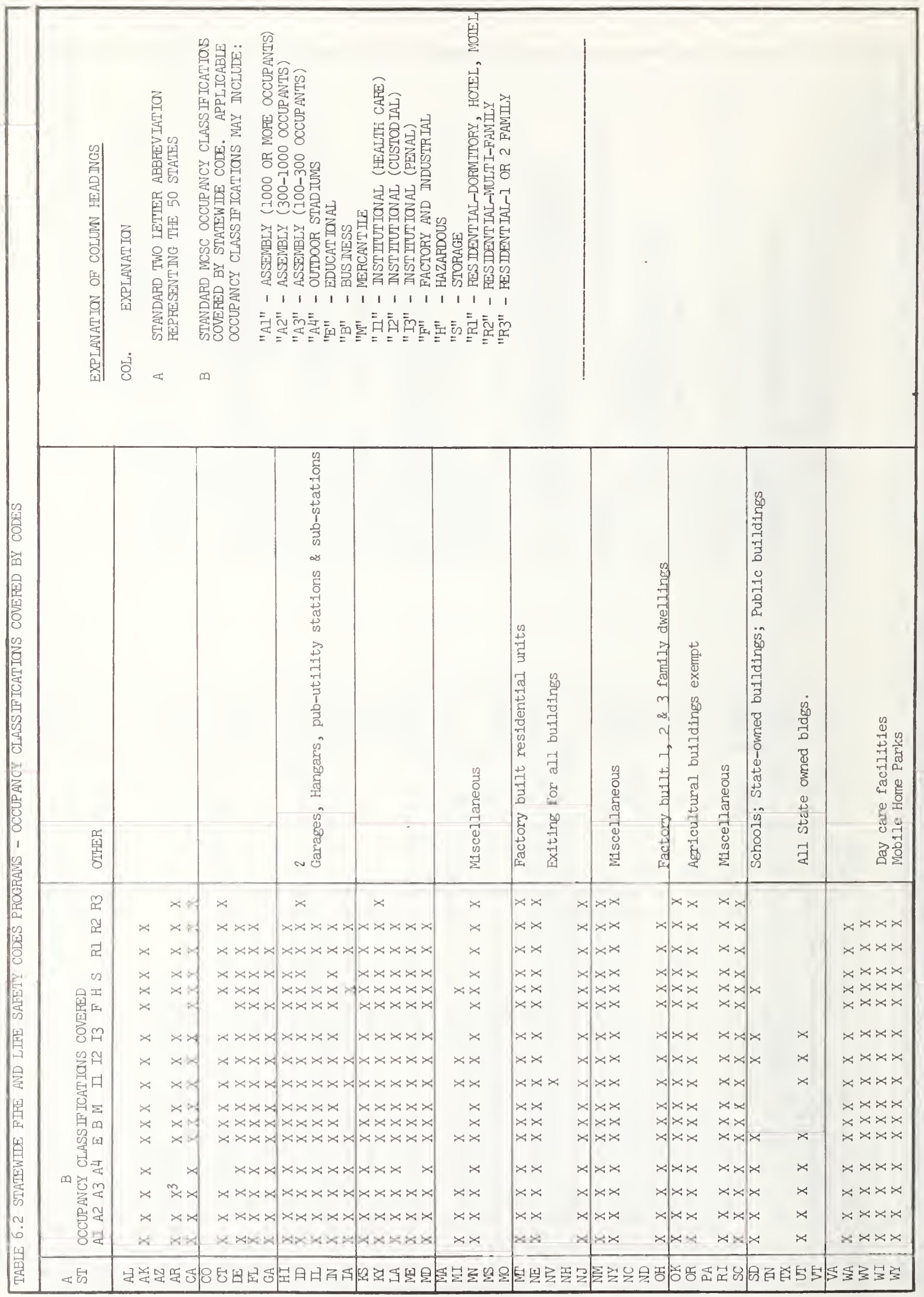



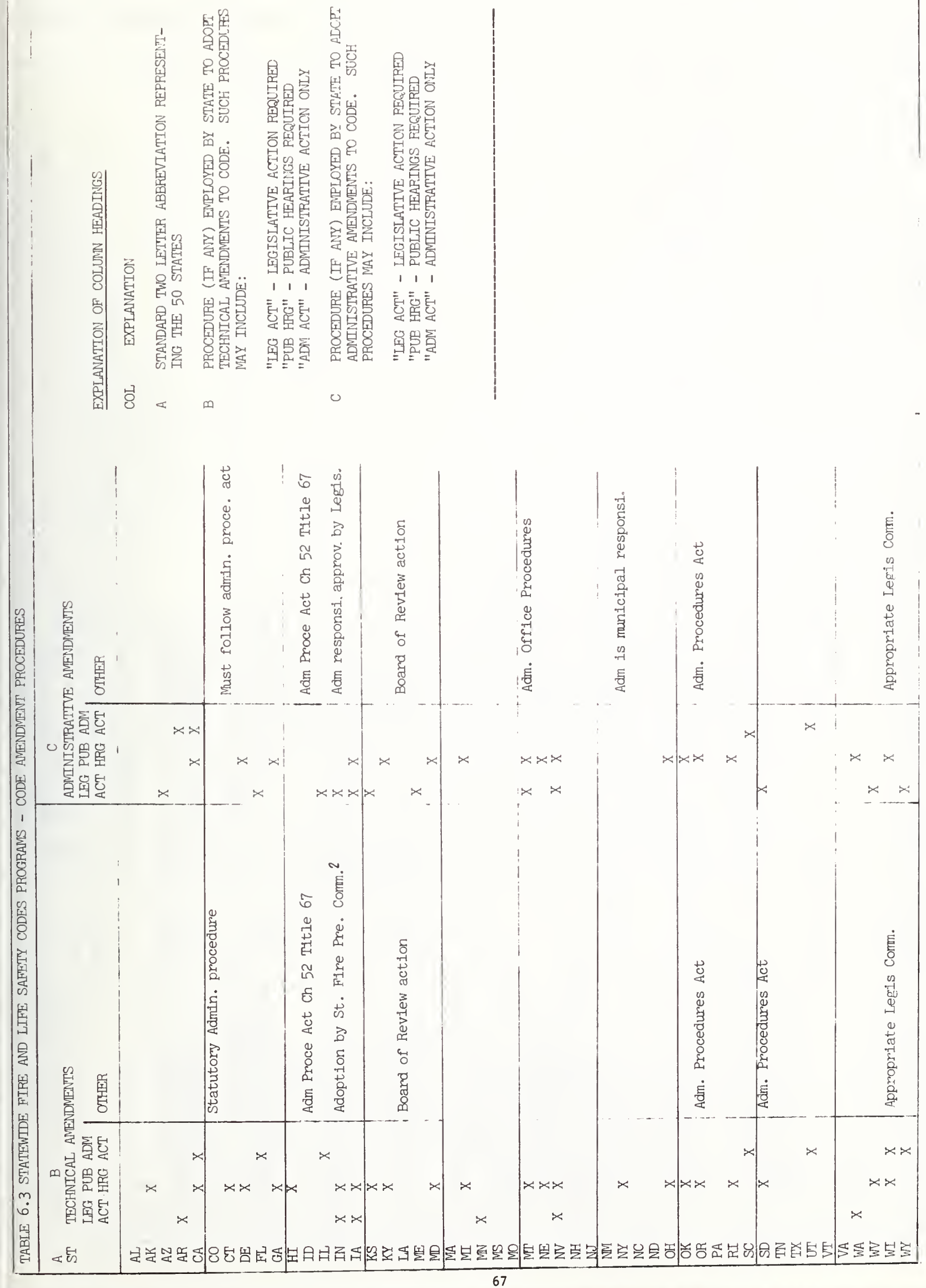


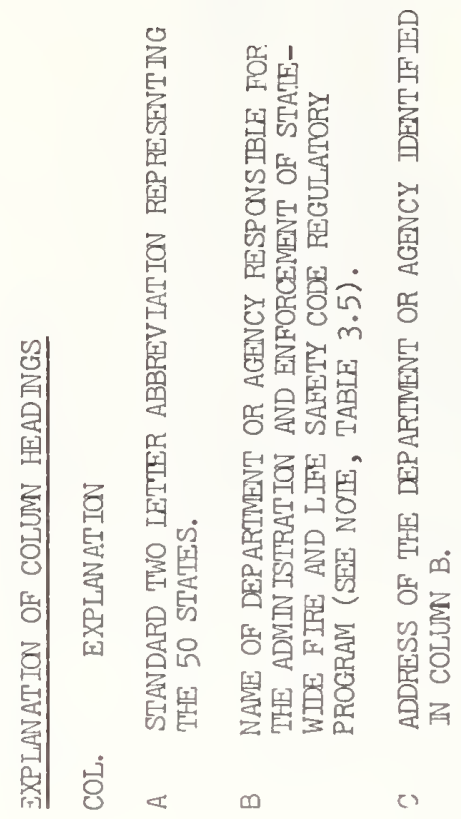

\begin{tabular}{|c|c|c|c|c|c|c|c|c|c|c|c|c|}
\hline 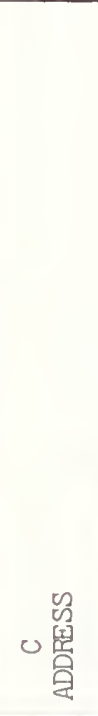 & 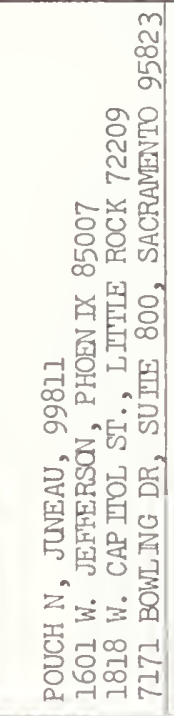 & 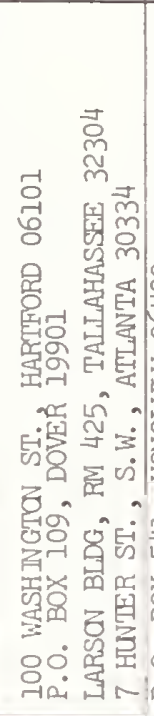 & 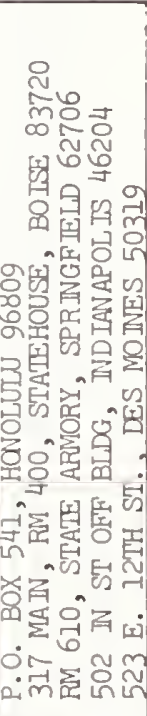 & 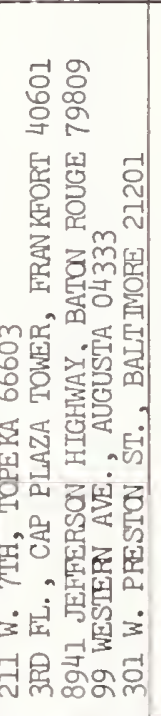 & 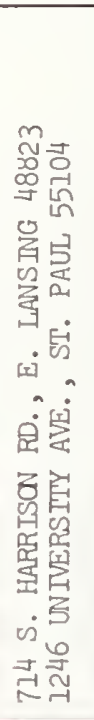 & 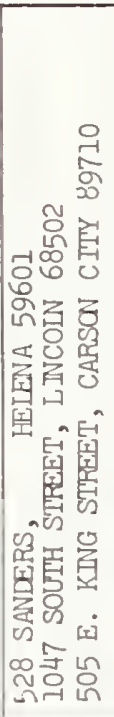 & 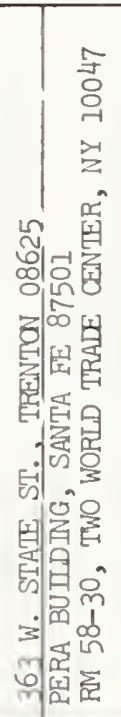 & 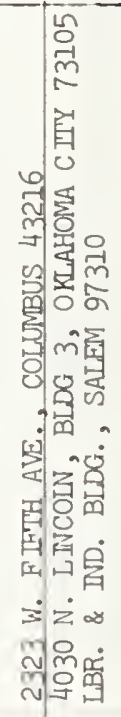 & 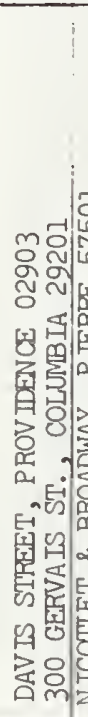 & & 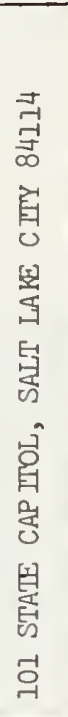 & 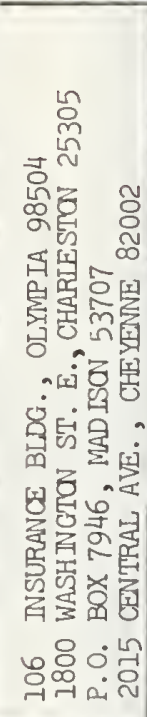 \\
\hline 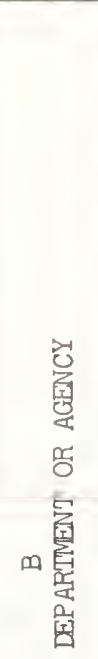 & 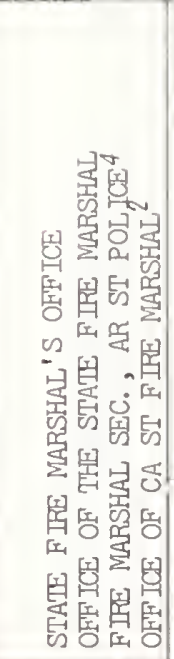 & 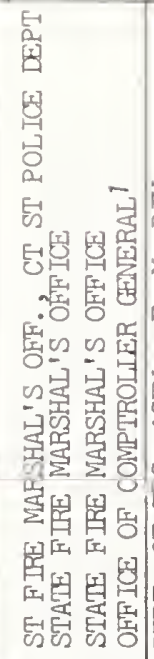 & 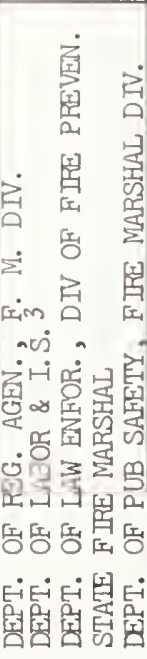 & 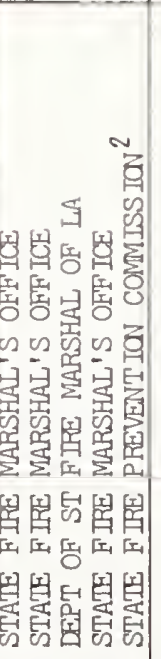 & 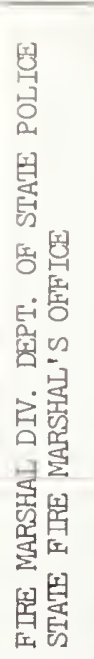 & 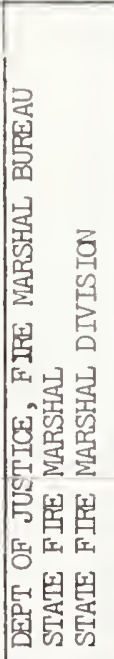 & 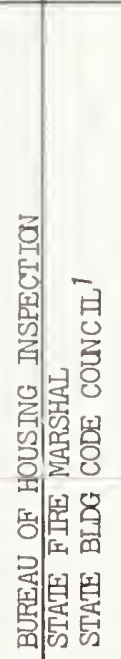 & 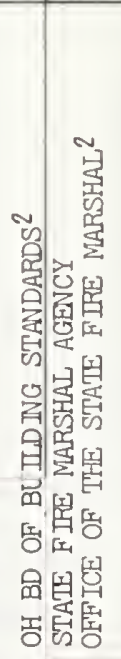 & 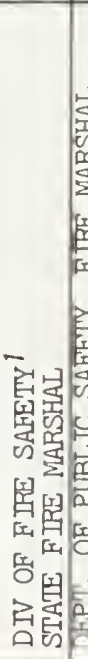 & & 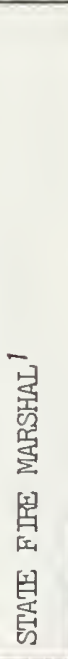 & 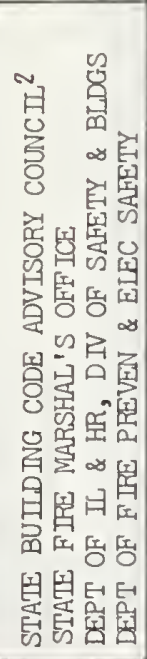 \\
\hline 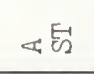 & 安运是炙 & & & & & & 2 & 列鼓 & 8 & & & ફ \\
\hline
\end{tabular}




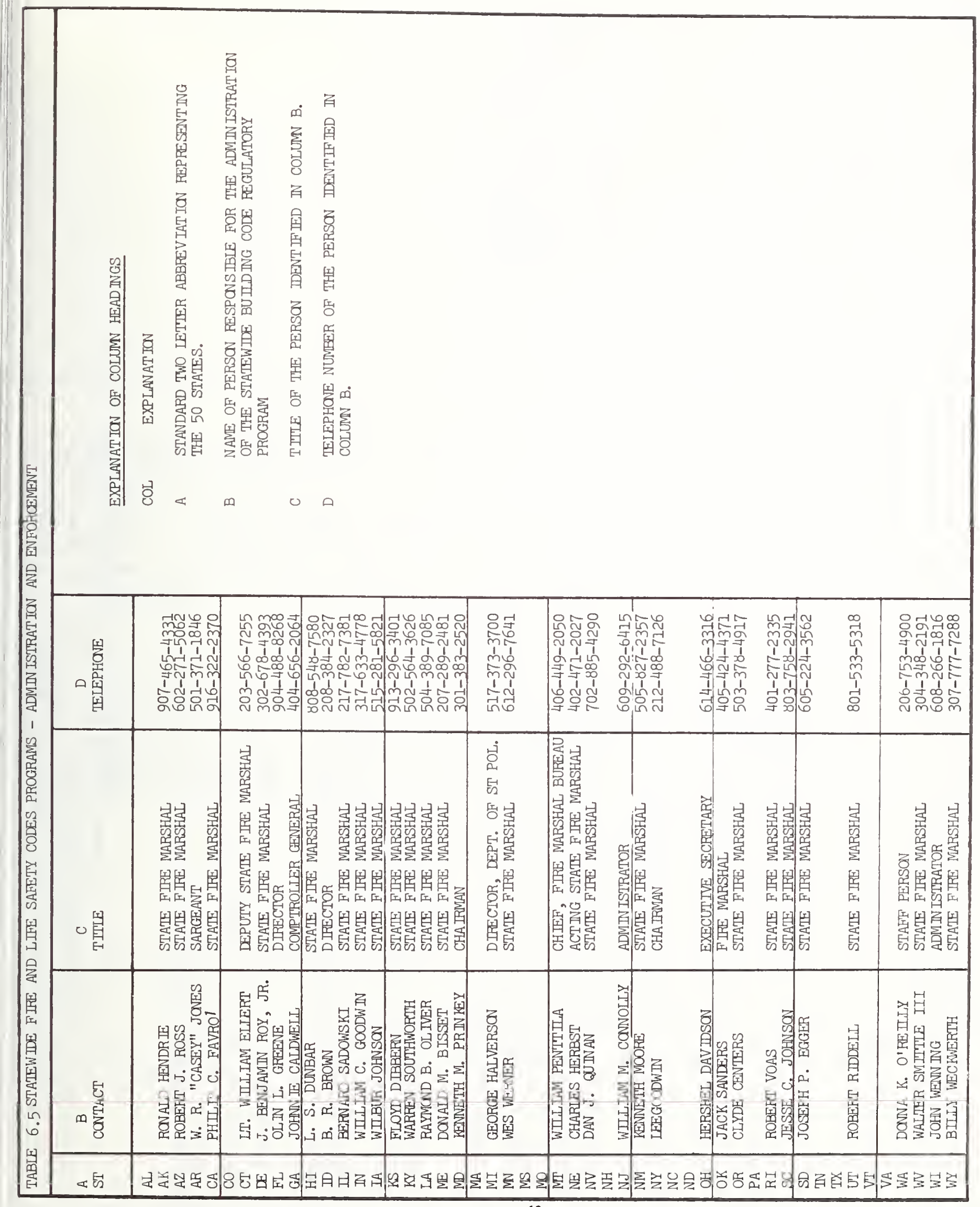




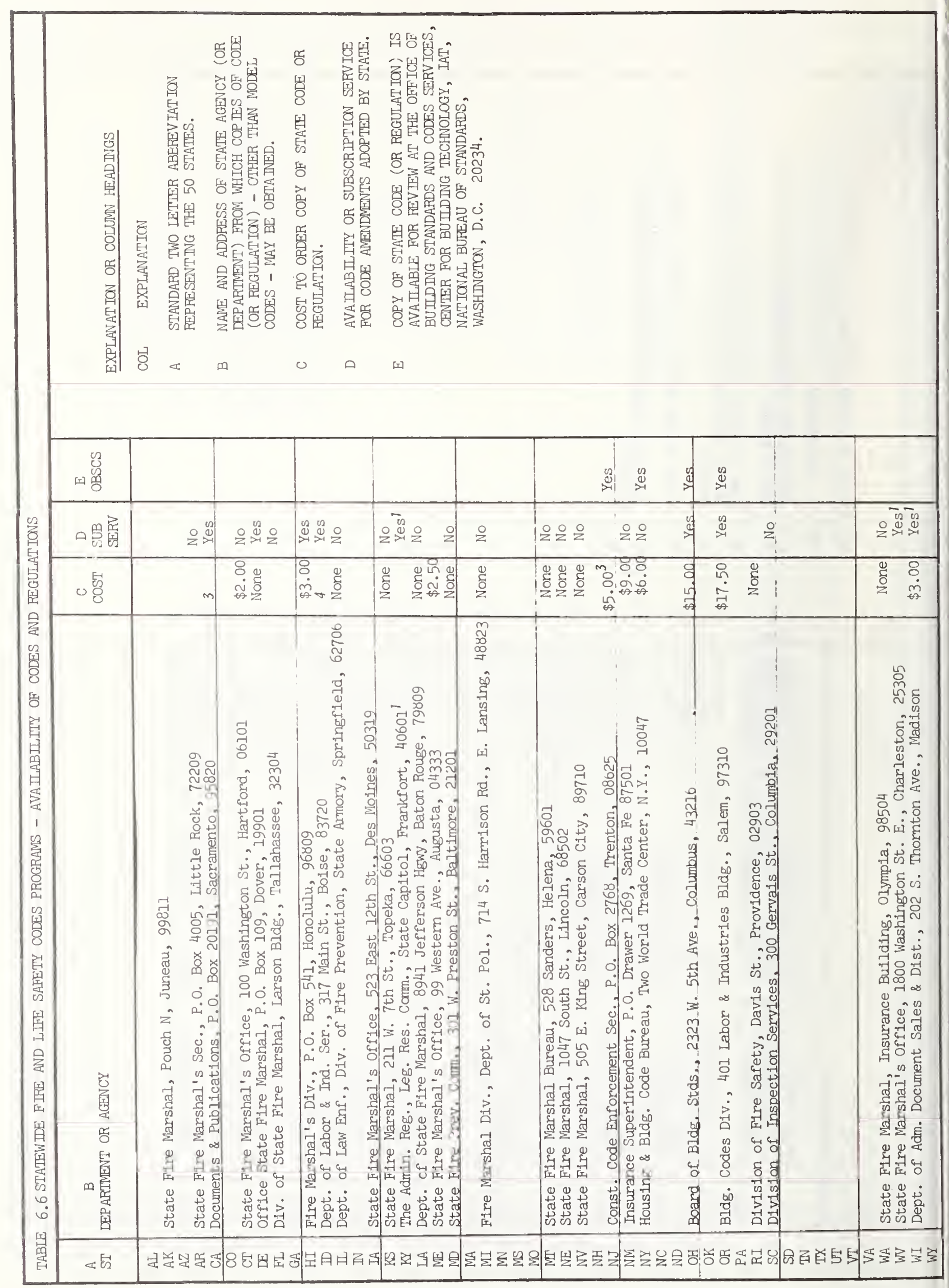


TABIE 6 STALEWIDE FIRE AND LIFE SAFETY CODE PROGRAMS

NOIES, GENERAL REMARYS

ALABAMA

ALASKA

ARIZONA

\section{ARKANSAS}

1. If enacting more stringent regulations.

2. Cities may adopt the Standard Building Code instead of the National Building Code.

3. Assembly Occupancy

$A I=A ; 1,000$ or more

$A 2=B ; 200-1,000$

$A 3=C ; 200$ or less

4. Enforcement: State Fire Marshal Section and local Fire Department.

CALIFORN IA

1. T-25, Chapter 1, (H \& S Code, Div. 13, Part 1.5).

2. Title 19 administered by the State Fire Marshal and Title 25 administered by the Dept. of Housing and Conmunity Development, Division of Codes and Standards, 1807 13th St., Sacramento, (916) 445-94\%1. (Title 25 is applicable to dwelling type occupanices.)

3. Title 25, $\$ 10.60$; Title 19, $\$ 10.28$.

COLORADO

CONNECTICUT

1. 1970 edition of NFPA 101 - Life Safety Code adopted.

DELAWARE

1. 1973 Edition of NFPA 101 as well as complete 10 vol. National Fire Codes, 19'/3 Edition.

FLORDA 
TABIE 6STAIEWIDE FIRE AND LIFE SAFETY CODE PROGRAMS (continued)

GEORGIA

1. Enforcement agency: Georgia State Fire Marshal.'s Office, John R. (Bob) Gore, Jr., State Fire Marshal, (404) 656-2064.

HAWAII

IDAHO

1. Department of Labor and I.S. Rules and Regulations. Also IC 39-4101, Idaho Building Code Advisory Act 1975.

2. Occup. exemptions a) Farms, b) Chem. plants and min. extr. structures, c) Teleconmunication facilities, d) Temporary construction facilities.

3. Cities and counties have option for enforcement under the provisions of Sec. 39-4116, Idaho Code.

4. Fire code - \$7.50; Rules and Regulations - \$3.00.

\section{IIIINOIS}

\section{INDIANA}

1. Reference only to National Fire Codes, if not treated by Uniform Building Code (1973 modified).

\section{IOWA}

1. Adopts NFPA 30 (1972) \& NFPA 54 \& 58 (1969).

\section{KANSAS}

1. NFPA 101 - 1967 edition, Health Care Facilities and NFPA 101 - 1970 edition, places of Assembly, Residential occupanices, Mercantile, office, Industrial storage and Miscellaneous studies.

KENTUCKY

1. Technical and administrative changes are published in the Kentucky Administrative Register. Cost of Code changes subscription service is $\$ 24.00$ per year.

\section{LOUISIANA}

1. Under the act the fire marshal is authorized to compile a written set of rules and regulations governing fire hazard and life safety requirements.

2. Also 19'74 amendments to the 1973 Standard Building Code applicable to Hi-rise structures (Section 518, Chapter IV) and any requirements of the 1973 Standard Code necessary to interpret, elucidate or explain these amendments. 
TABIE 6 STAIEWIDE FIRE AND LIFE SAFETY CODE PROGRAMS (continued)

MAINE

MARYLAND

1. NFPA Life Safety Code plus certain other NFPA Standards.

2. Enforcement agency: Office of State Fire Marshal, James Robertson, State Fire Marshal (301) 383-2520.

MASSACHUSETTS

MICHIGAN

MINNESOTA

1. Administration of the Uniform Building code is the responsibility of the Building Code Division.

\section{MISSISSIPPI}

MISSOURI

MONTANA

1. NFPA Life Safety Code plus certain other NFPA Standards and Codes.

NEBRASKA

NEVADA

1. The State Fire Marshal enforces the exiting and fire protection provisions of the Uniform Building Code, in addition to NFPA 101 and a number of other NFPA Standards.

NEW HAMPSHIRE 
TABIE 6STATEWIDE FTRE AND LIFE SAFETY CODE PROGRAMS (continued)

NEW JERSEY

1. The State Fire Marshal's Office of the Treasury Department is responsible for enforcement of fire safety standards and precautions (National Fire Codes) in the States own facilities. The State Fire Marshal is John McQuade (609) 292-3730.

2. The Uniform Construction Code, Fire Protection Subcode consists of various Articles and Sections of the Basic Building Code and the National Electrical Code.

3. New Jersey Uniform Construction Code Regulations relate to Administration and Enforcement and Building, Plumbing, Electical and Fire Protection Subcodes.

NEW NEXICO

NEW YORK

1. Fire-Safety Requirements, Part 4 of the General Building Construction booklet.

2. Enforcement is municipal responsibility.

NORTH CAROLINA

NORTH DAKOTA

OHIO

1. Fire Safety Requirements contained throughout Ohio Building Code.

2. Enforcement agency: Division of Factory and Building Inspection, Department of Industrial Relations, Jerald Bruce, Chief, telephone number (614) 466-4611.

\section{OKLAHOMA}

1. Selected volumes of The National Fire Codes are promulgated.

OREGON

1. Readopted in 1925.

2. Fire Marshal promulgates; Building Code Division enforces for new construction (both State and Local). Trevor Jacobson, Building Codes Administrator (503) 378-8227. State and local Fire Marshal's maintain.

PENNSYLVAN IA

RHODE ISLAND

1. Enforcement agency: Stat,e Building Codes Standard Committee, Dept. of Cormunity Affairs, Joseph Cirillo, State Building Comission, 150 Washington St., Providence, 02903 telephone (401) 277-3032. 
TABIE 6STATEWIDE FIRE AND LIFE SAFETY CODE PROGRAMS (continued)

SOUTH CAROLINA

1. Standard Building Code.

SOUTH DAKOTA

TENNESSEE

TEXAS

UTAH

1. Enforcement of occupancies other than schools and State-owned buildings by local fire authority.

VERMONT

VIRGINIA

WASHINGTON

1. NFPA reports Washington has adopted NFPA 101 (1970).

2. Administration and enforcement is the responsibility of the local jurisdictions.

\section{WEST VIRGINIA}

1. Amendments available from Secretary of State's Office, Capitol Building, Charleston, W. Va., 25305.

\section{WISCONSIN}

1. Subscription service for amendments is $\$ 3.00$ per year.

WYOMING 


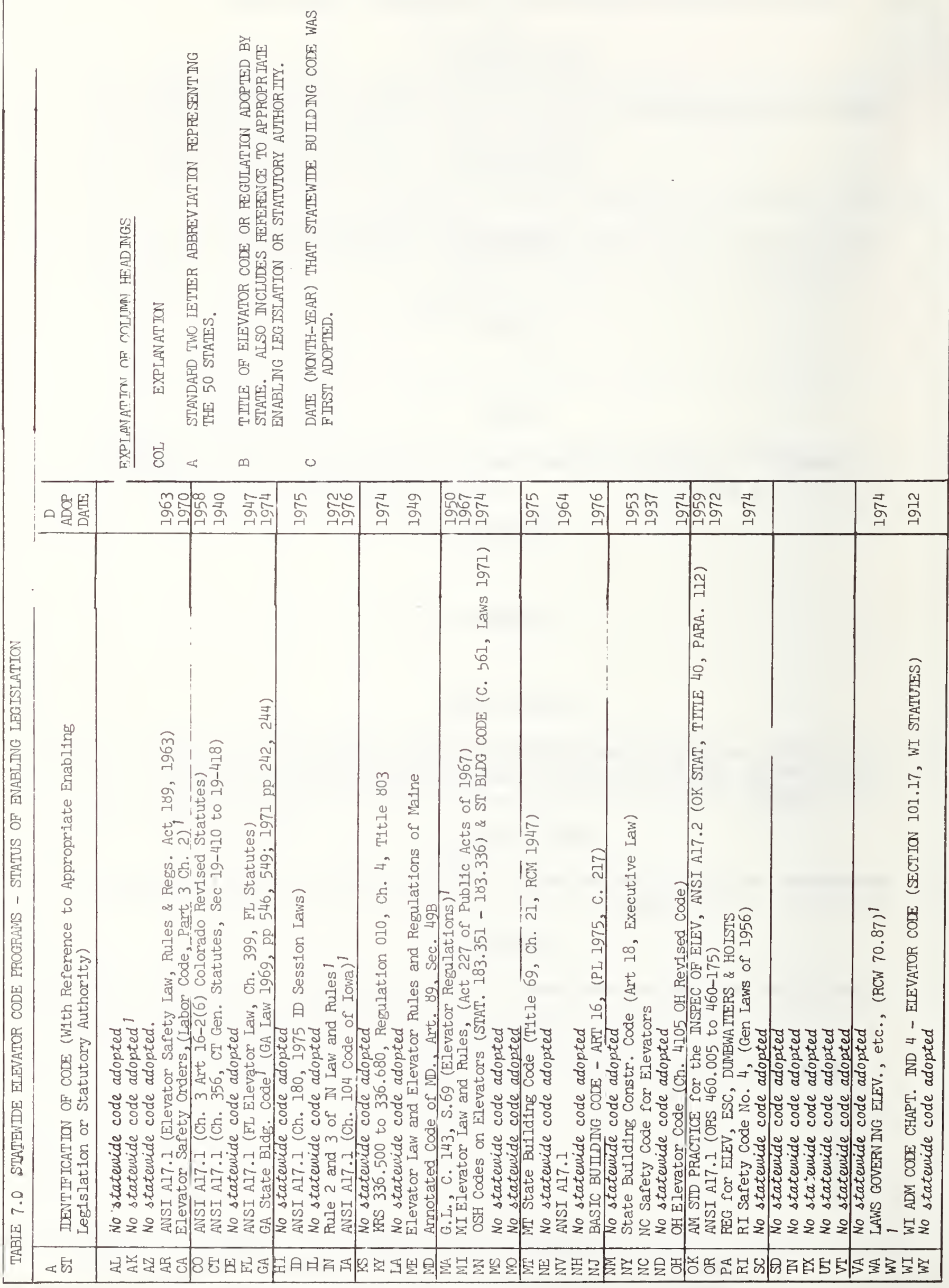



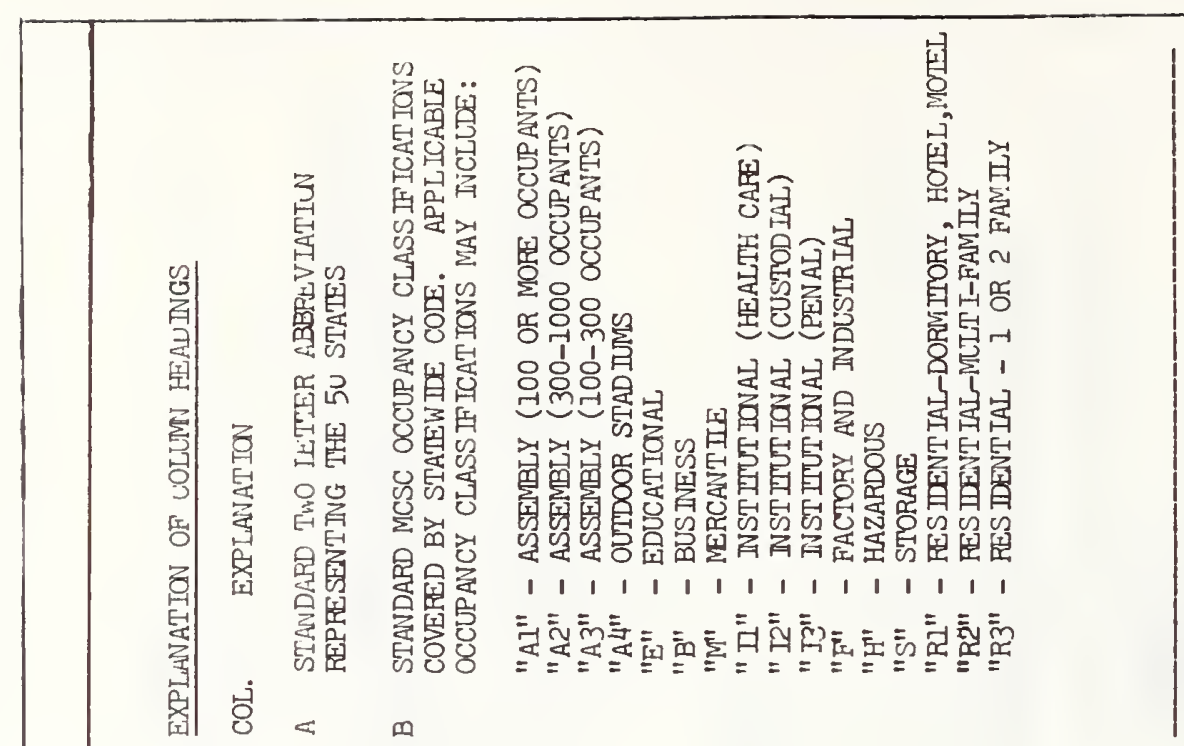

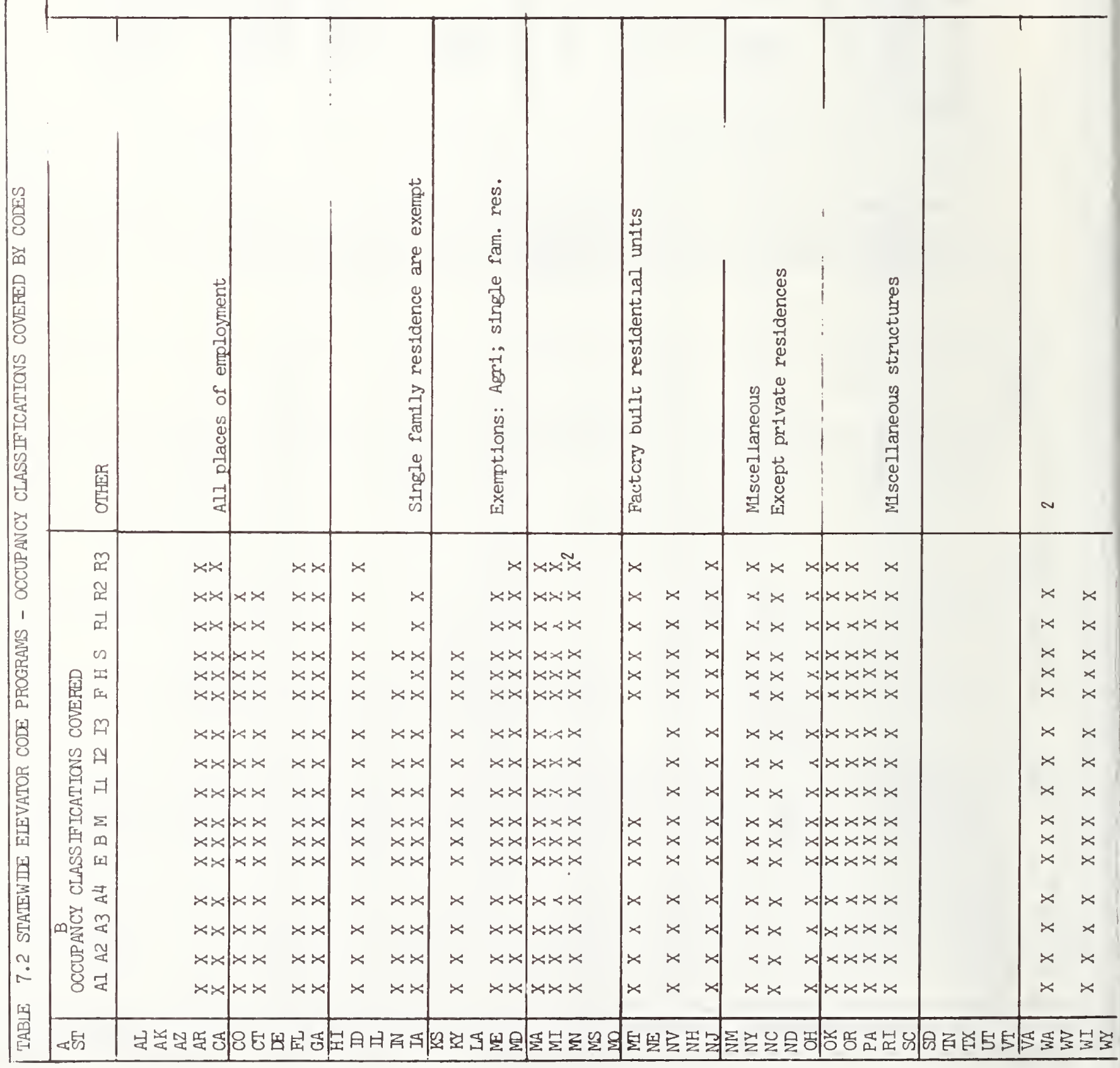



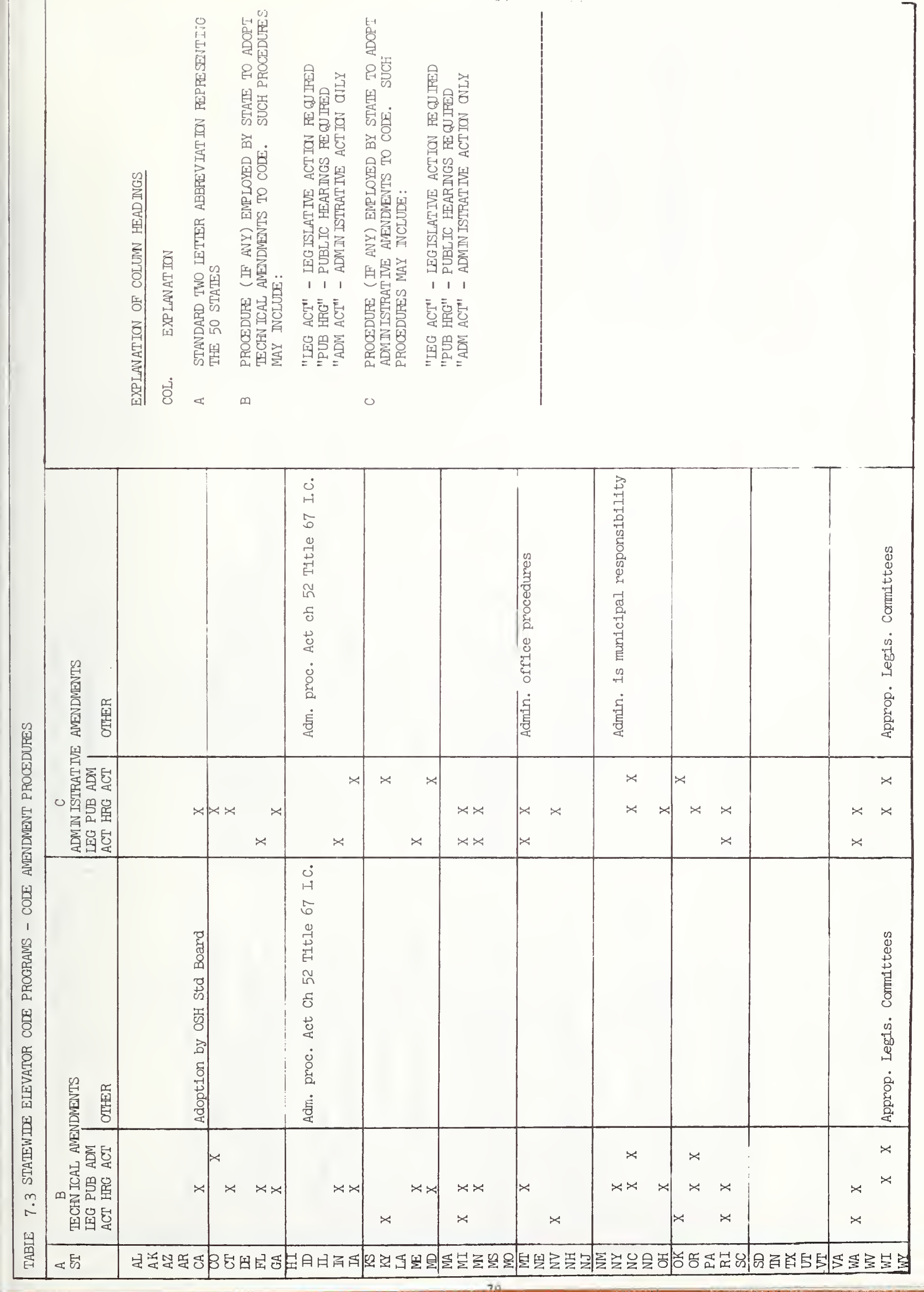


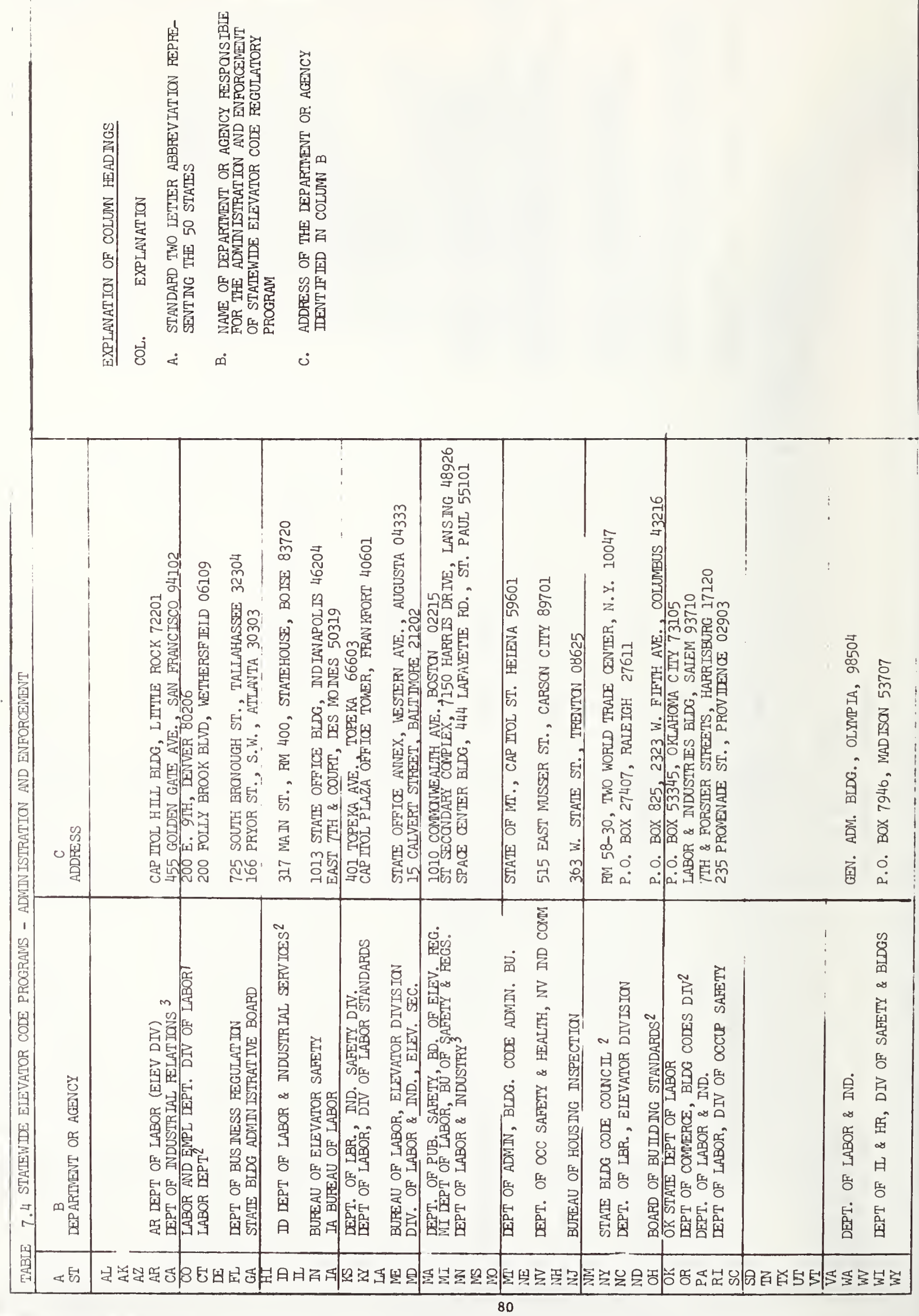



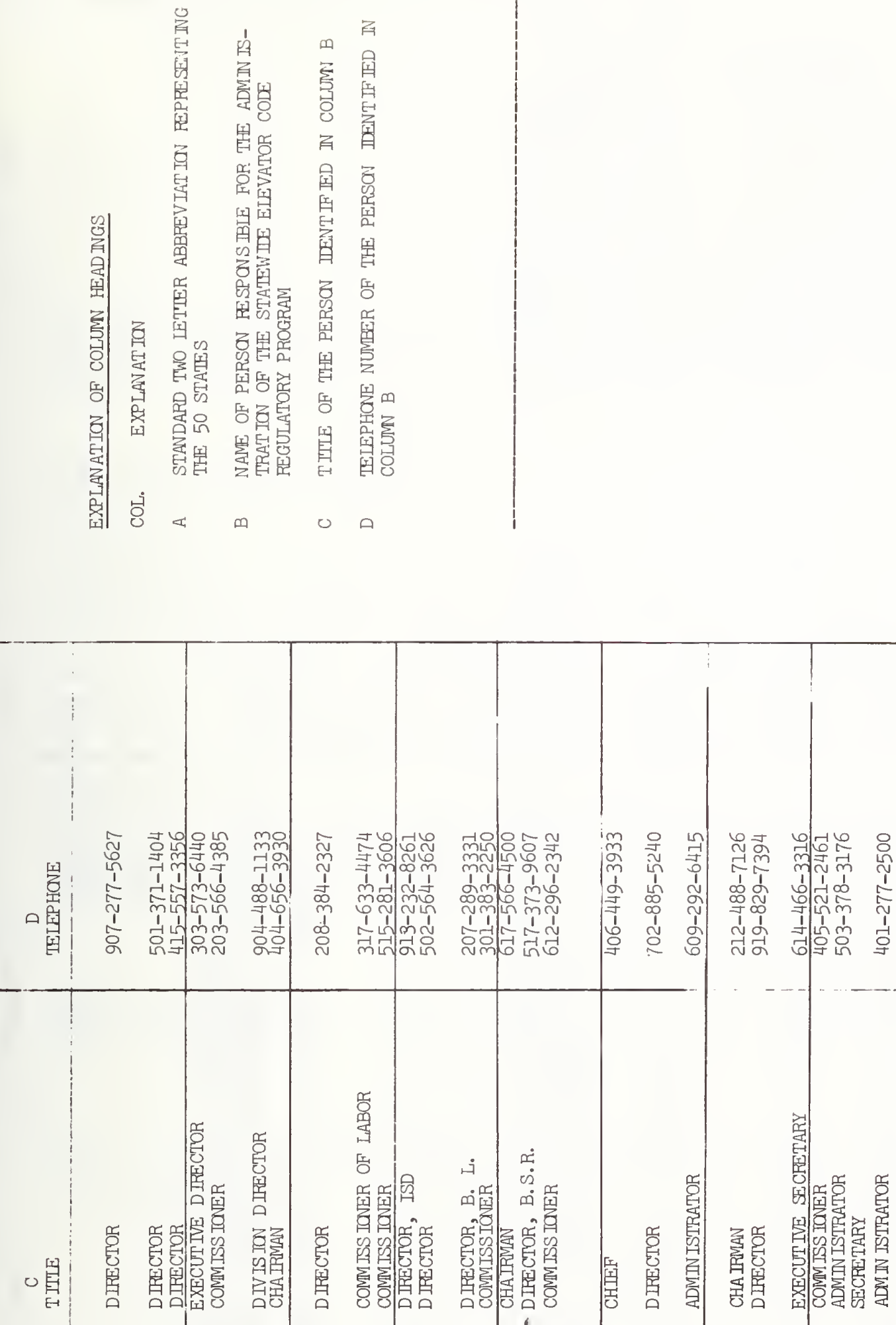

तब 


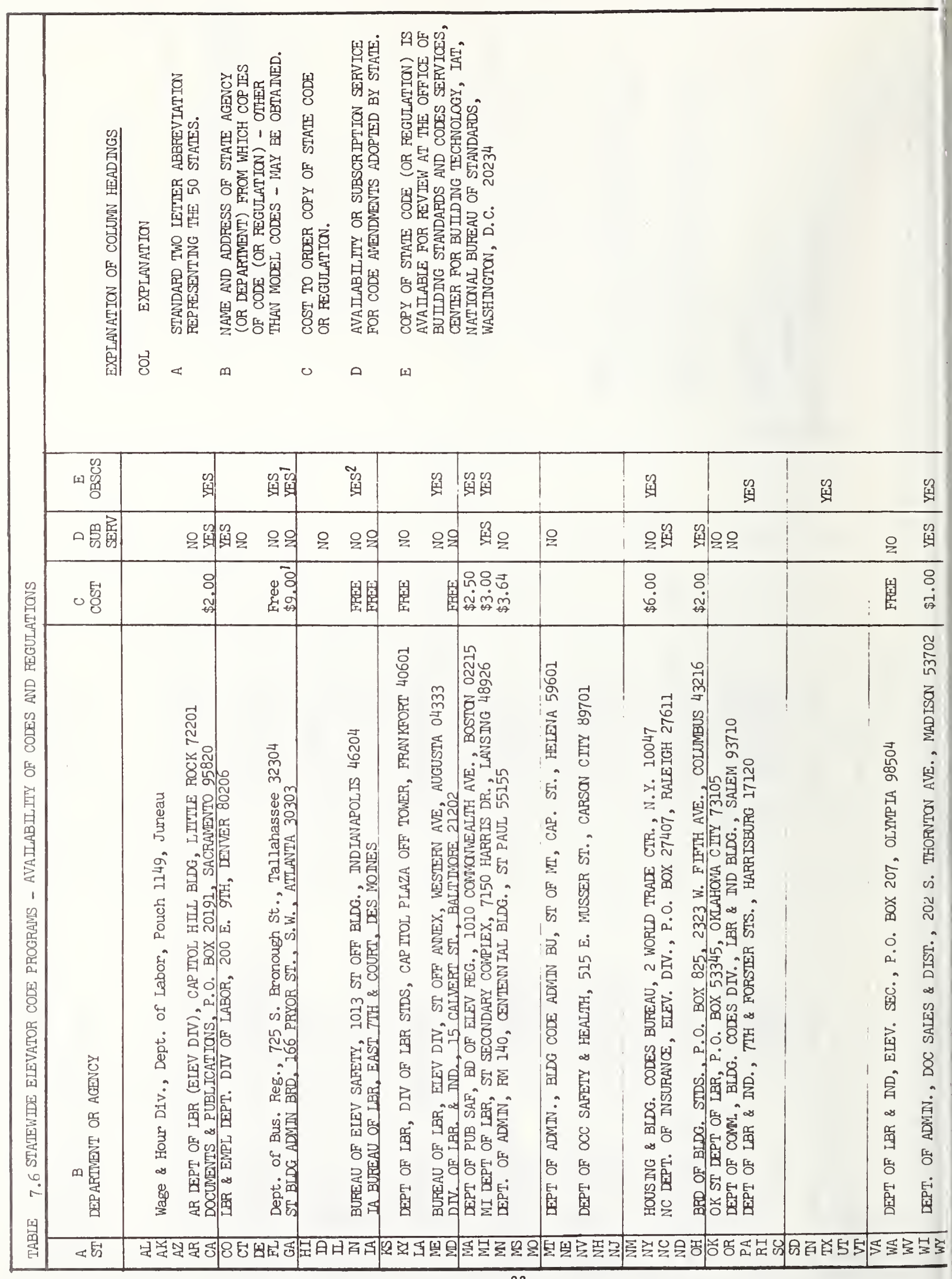


NOIES, GENERAL REMARKS

ALABAMA

ALASKA

1. Detailed information was unknown at the time of response to the preliminary version of this table. ANSI Al7.I is reported in use.

ARIZONA

1. $75 \%$ of municipalities have adopted ANSI 17.1.

ARKANSAS

\section{CALIFORN IA}

1. Dwelling occupancies, code/authority T-24, Pt '2, Ch. B5l; T-25 CAC Ch. 1, Sec. 1070 (Health and Safety Code Div. 13, Pt 1.5).

2. The city of Los Angeles is excepted.

3. Title 24, Part 7.

4. Enforcement Agency: Div. of Industrial Safety, R. W. Wilkins, Chief, Tel (415) 557-1946; Dwelling Occupancy Enforcement Agency: Dept. of Housing and Community Dev., Div. of Codes and Standards, Xavier Mendoza, Chief, Tel (916) 445-9471.

\section{COLORADO}

1. Enforcement Agency: Div. of Labor, Public Safety Section, James A. Underwood, Chief, Tel (303) 893-1233.

CONNECTICUT

1. ANSI 17.1 including supplementary $1 a-1972,1 b-1973$ and $1 c-1974$.

2. Enforcement Agency: Factory Inspection Div. Leo Alix, Director $\mathrm{Tel}$ (203) 566-4550.

DELAWARE

FLORDA

GEORGIA

1. Chapter XXIV of the State Building Code relates to Elevators and Escalators. It references ANSI Al7.1, ANSI A90.1, as well as Section 701 of the State Building Code. 
TABLE 7 STATEWDE EIEVATOR CODE PROGRAMS (contInued)

HAWAII

IDAHO

1. Includes supplement Al7.1b-1973.

2. Cities and counties have the option for administration under the provisions of Sec. 39-4116, Idaho Code. In areas where local government doesn't so opt, the Idaho Dept. of Labor and Industrial Services administers.

IILINOIS

\section{INDIANA}

1. ANSI Al7.I - 1971 for Elevators, Dumbwaiters, etc.; ANSI A90.I (1969) Safety Std. for Manlifts; and ANSI A10.4 (1963) Safety Requirements for Workman's Hoist.

2. Indiana Elevator Law and Rules (supplement to standards noted in 1 above).

IOWA

1. Includes supplements and excludes Part V.

KANSAS

KENTUCKY

1. City of Louisville and Jefferson County are exempt.

2. Reg 101, Ch. 4, Title 803.

3. Following Sections of A17.1-1971 are not adopted:

a. 500.1 to $502.15 ; 700.4 b ; 700.5 ; 700.7 b ; 700.10 b ; 707.4 ; 900.1$ - 903.1.

IOUISIANA

MAINE

MARYLAND 
TABIE 7 STATEWIDE EIEVATOR CODE PROGRAMS (continued)

\section{MASSACHUSETTS}

1. Current regulations are found in ELV-2 (Revised 1971). Elevators etc., installed in accordance to regulations in effect prior to March 9, 1950, shall be maintained in conformity to ELV-l Revised.

\section{MICHIGAN}

1. Cities of Detriot and Dearborm are exempt.

2. State written codes apply to: 1) Incline Lifts, 2) Sewer Lift Personnel Lifts, 3) Wheel Chair Elevating Dev., 4) One Man Hand Power and One Man Electric Elevators.

\section{MINNESOTA}

1. Cities of Minneapolis and St. Paul are exempt although they enforce the same standards as the State.

2. Elevators not used in places of employment are regulated by the State Building code. An amendment covering elevators etc., is available for \$.75. Administration is by the Building Code Division, Department of Administration, William F. Anderson, Director, (612) 296-4626.

3. Enforcement is by the Minnesota Occupational Safety and Health Division, Russell B. Swanson, Deputy Commissioner, Tel (612) 296-6529.

MISSISSIPPI

MISSOURI

MONTANA

NEBRASKA

NEVADA

NEW HAIMS SHIRE

NEW JERSEY 
NEW YORK

1. The code has been adopted by 642 municipalities: 54 cities, 277 towns, 311 villages.

2. Part 5, Equipment Requirements, of "General Building Construction."

3. Enforcement of State Building Construction Code is responsibility of municipalities.

NORTH CAROLINA

NORTH DAKOTA

OHIO

1. Also All3.I has been adopted.

2. Enforcement is by the Division of Elevator Inspection, Box 825, 2323 West fifth Avenue, Columbus 43216. Frank Amold is Division Chief, Tel (614) 466-6127.

OKLAHOMA

OREGON

1. Model Codes:

a. ANSI Al7.1-1971 w1th supplements Al7.1A-72 and Al7.1B-73.

b. Al7.1-1960 for elevators installed before $7 / 71$.

c. USAS A90.1-1969 and various state regulations.

2. Enforcement by the Elevator Safety Section of the Building Code Division, Labor and Industries Building, Salem 97310. L. D. Sisson, Chief, Tel (503) 378-8499.

RHODE ISLAND

SOUTH CAROLINA

SOUTH DAKOTA

TENNESSEE 
TABIE 7 STATEWIDE EIEVATOR CODE PROGRAMS (continued)

\section{TEXAS}

UTAH

VERMONT

VIRGINIA

\section{WASHINGTON}

1. Also Safety Rules Governing Existing Elevators, etc. (WAC 296-81). Also includes ANSI Al13.1-1964 and various State regulations.

2. Regulations cover all places of employment except in three cities with codes (Seattle, Tacoma and Spokane). All county and State buildings are covered, except grain elevators, as well as Federal building by request.

\section{WEST VIRGINIA}

1. The elevator code would apply only where NFPA, Fire prevention code and National Building Codes indicates.

WISCONSIN

WYOMING 


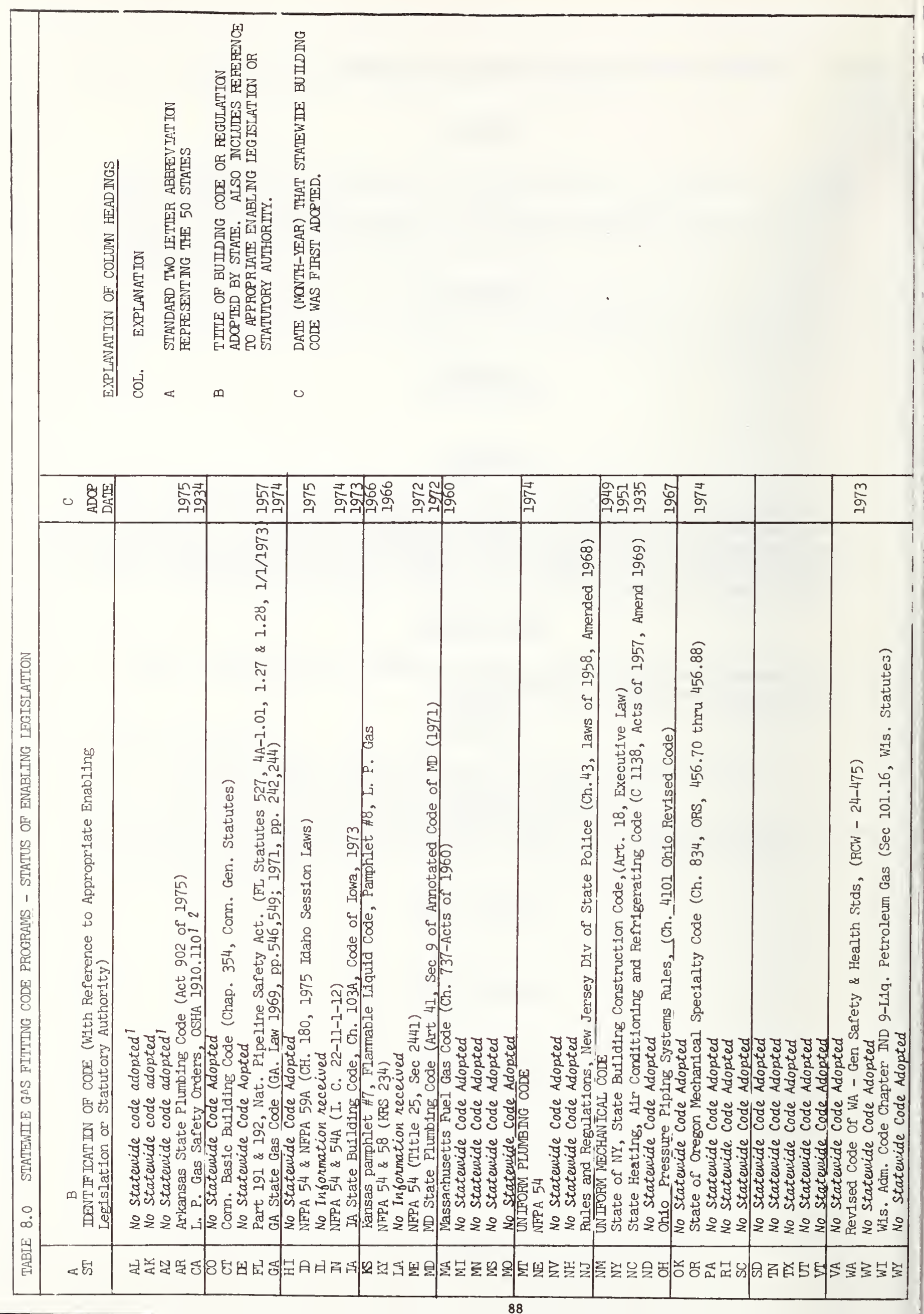




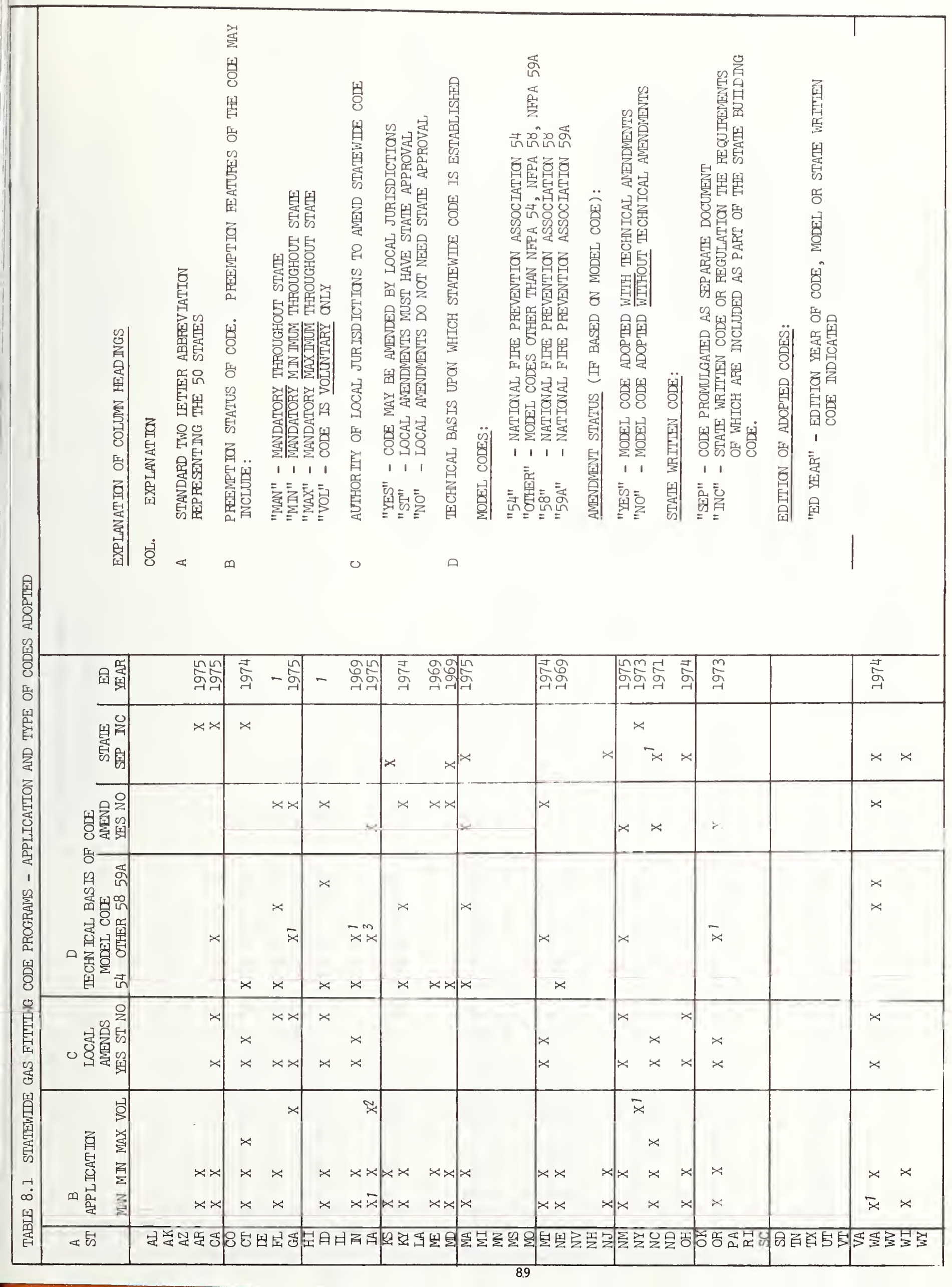




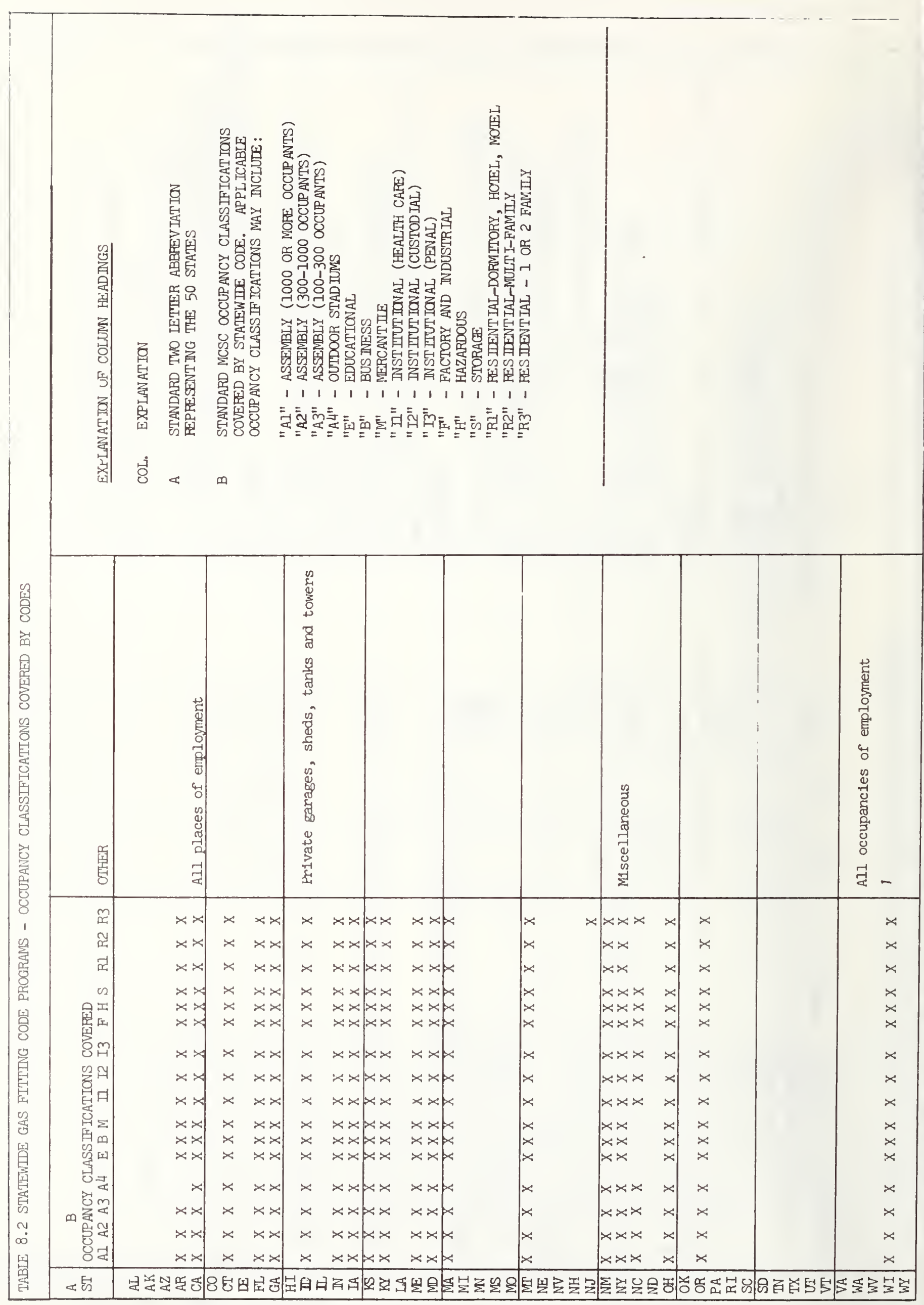




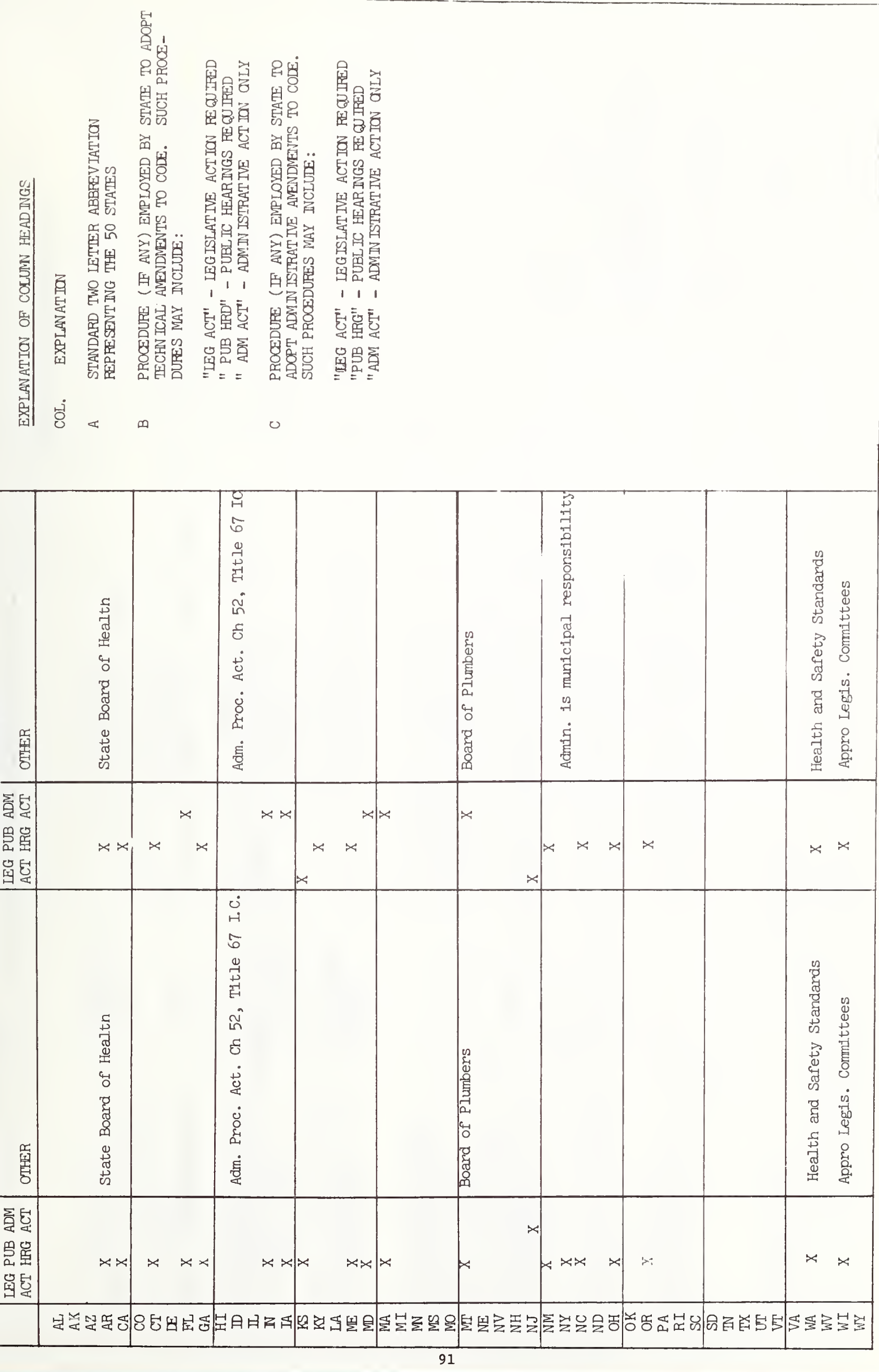




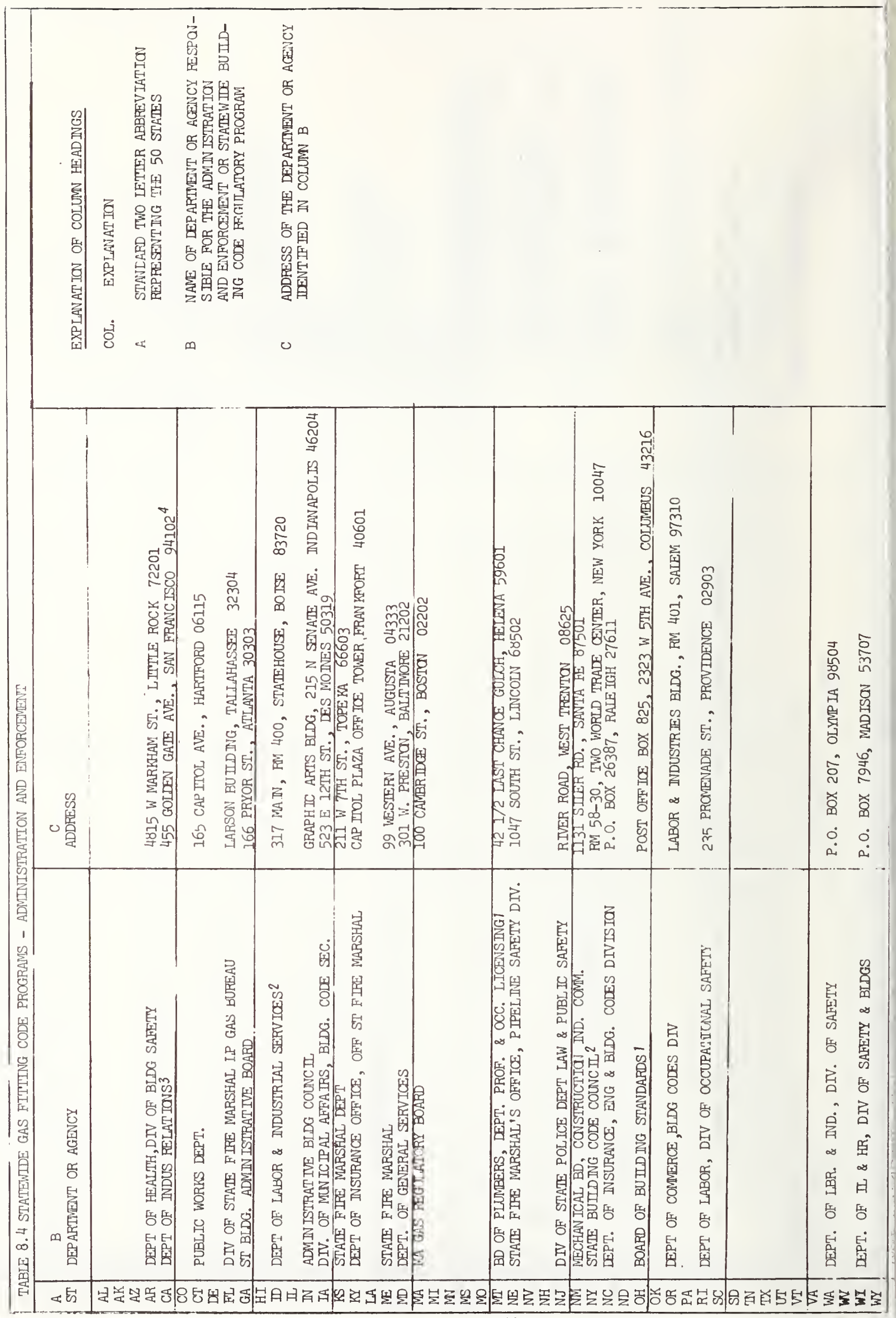




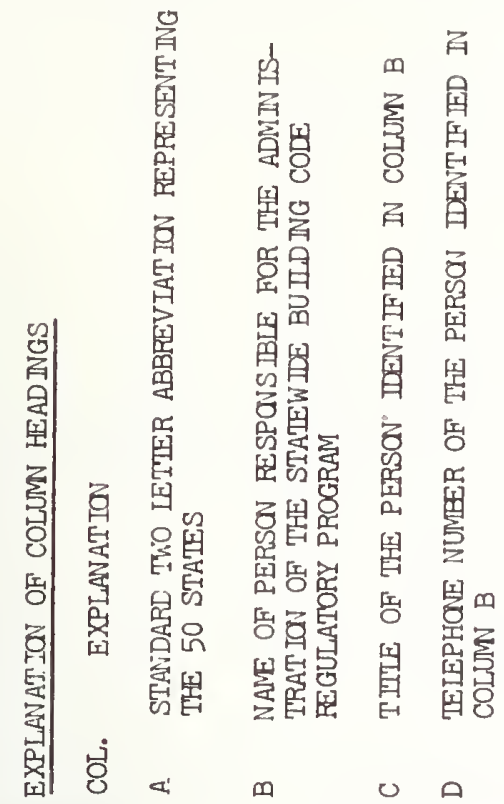

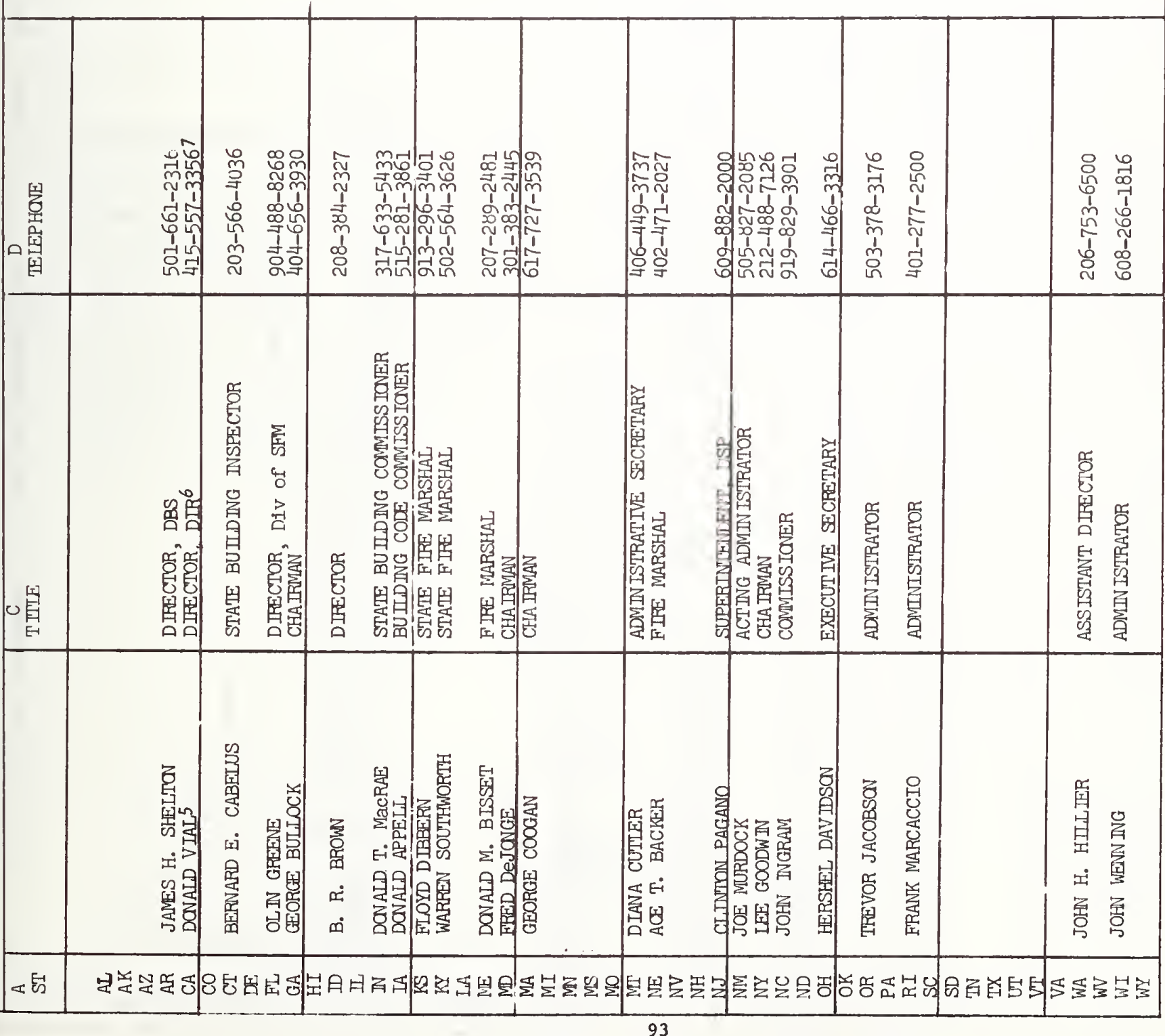




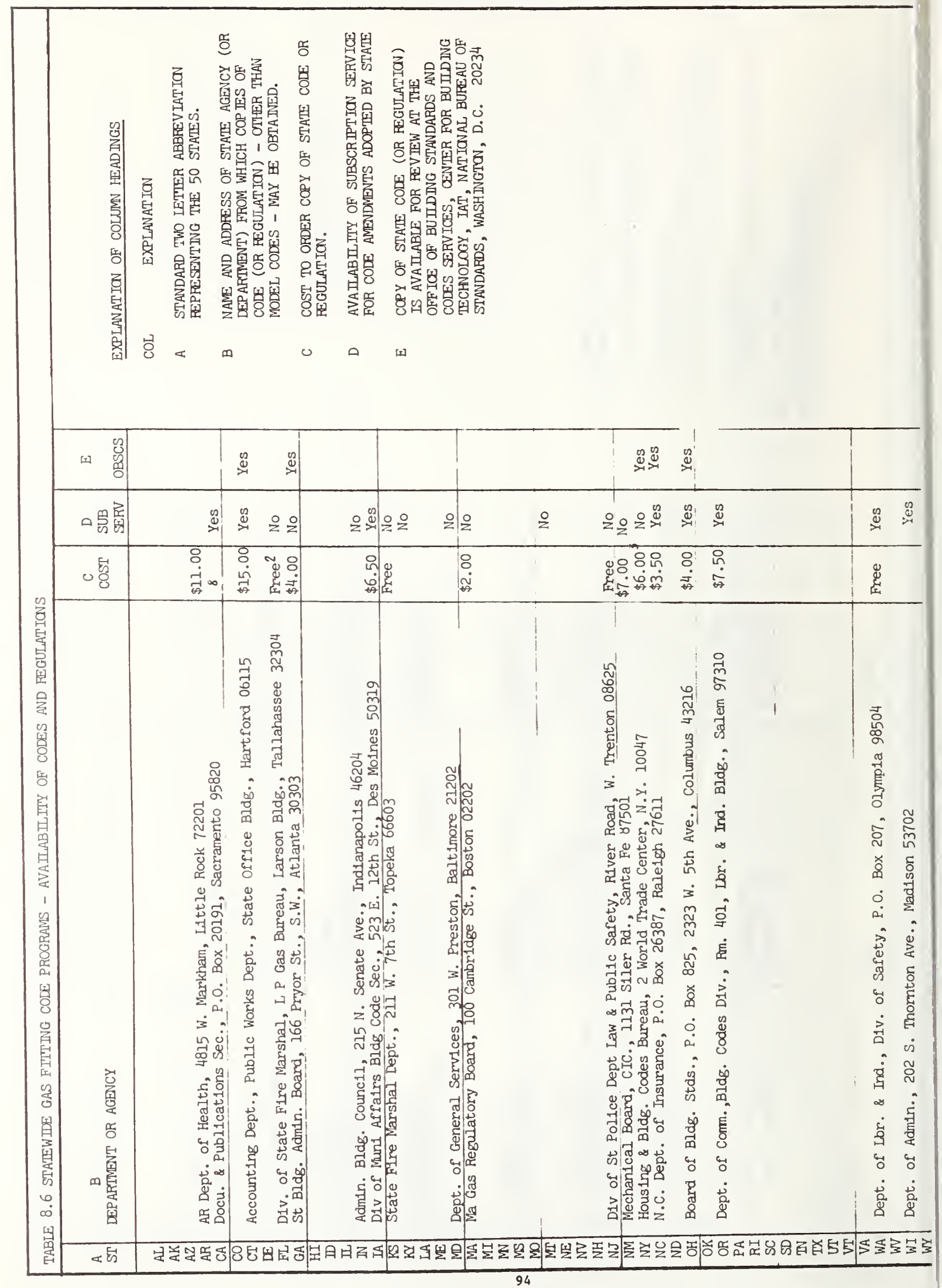


NOIES, GENERAL REMARYS

ALABAMA

1. All state funded construction must comply with the Standard Gas Code $(\mathrm{SBC})$.

\section{ALASKA}

\section{ARIZONA}

1. Approximately $75 \%$ of cities, counties and local jurisdictions have adopted the Uniform Plumbing Code.

\section{ARKANSAS}

\section{CALIFORN IA}

1. Code Reference CA T-24 C.A.C. Pt. 6 Div. T-8, Subdiv. 1, Chap. 4 (Places of Employment)

2. CA T-25 C.A.C. Chap. 1, Sec. 1078 and Chap. 5, Sec. 5400, UPC '73 and National Pipeline Safety Act; T-49 Transportation Chap. 1, Pt. 192 (Health and Safety Code Div. 13 Pt. 1.5 and Pt. 2 and Pt. 2.1) applies to residential occupancies and mobile home parks.

3. Dept. of Housing and Community Development, Div. of Codes and Standards.

4. 1807 13th Street, Sacramento, Califormia 95814.

6 \& 7. Residential occupancies administered by the Division of Codes and Standards, Xavier Mendoza, Chief, Tel (916) 445-9471.

8. $\$ 5.00 \mathrm{~L}$. P. Gas Safety Orders $\$ 2.12$ T-25 Chap. 1 $\$ 2.54$ T-25 Chap. 5

COIORADO

CONNECTICUT

DELAWARE

FLORIDA

1. NFPA No. 54, 1969 Edition: NFPA No. 58, 1972 Edition.

2. State Rules and Regulations; free. 
TABIE 8 STATEWIDE GAS FIITING CODE PROGRAMS (continued)

GEORGIA

1. Southern Gas Code.

HAWAII

IDAHO

1. NFPA No. 54, 1974 Edition; NFPA No. 59A, 1972 Edition.

2. Cities and counties have the option of administration and enforcement. In those areas where local govermment doesn't so opt, IDLIS will provide administration and enforcement.

\section{IILINOIS}

INDIANA

1. Also NFPA No. 54A, 1969.

IOWA

1. Mandatory for State-owned and factory bullt buildings.

2. 7 cities and 1 county.

3. Uniform Plumbing Code and Uniform Mechanical Code (Fuel Gas Piping Chapters).

KANSAS

KENTUCKY

LOUISIANA

MAINE

MARYLAND

MASSACHUSETTS 
TABLE 8 STAIEWIDE GAS FIITING CODE PROGRAMS (continued)

\author{
MICHIGAN
}

MINNESOTA

MISSISSIPP I

MISSOURI

\title{
MONTANA
}

1. Plumbing Board Jurisdiction over gas piping is not clear since the law refers to plumbing installation and maintenance and references are limited to water supply and sewer systems. (Section 66-2401, 66-2401.1, and 66.2416, R.C.M. 1947).

$$
\text { NEBRASKA }
$$

NEVADA

NEW HAMPSHIRE

NEW JERSEY

NEW MEXICO

NEW YORK

1. 54 cities, 277 towns and 311 villages have adopted the code.

2. Enforcement of State Building Construction Code is responsibility of municipalities of the State.

3. Code requirements relating to gas fittings are found in Part 5 of Equipment Requirements of the booklet, "General Building Construction." All four booklets of the code are $\$ 6.00$. 
TABIE 8 STATEWIDE GAS FITTING CODE PROGRAMS (continued)

NORTH CAROLDJA

1. Volume III of the North Carolina State Building Code, Heating, Air Conditioning, Refrigeration and Ventilation.

NORTH DAKOTA

OHIO

1. Enforcement agency: Division of Pressure Piping Inspection, Department of Industrial Relations, Bob Ross, Chief, (614) 466-2675.

OKLAHOMA

OREGON

1. 1973 Edition of the Uniform Mechanical Code.

PENNSYLVAN IA

RHODE ISLAND

SOUTH CAROLIINA

SOUTH DAKOTA

TENNESSEE

IEXAS

UTAH

VERMONT 
TABLE $y$ STAIEWIDE GAS FIITING CODE PROGRAMS (continued)

\author{
VIRGINIA
}

WASH INGTON

1. Safety Code.

\title{
WEST VIRGINIA
}

1. Gas Fitting Code would apply where NFPA, National Building Code and the Fire Prevention code would so stipulate.

\section{WISCONSIN}

1. Applies also to use of LP gas as motor fuel, containers mounted on vehicles, storage containers, and LP gas service stations.

WYOMING 


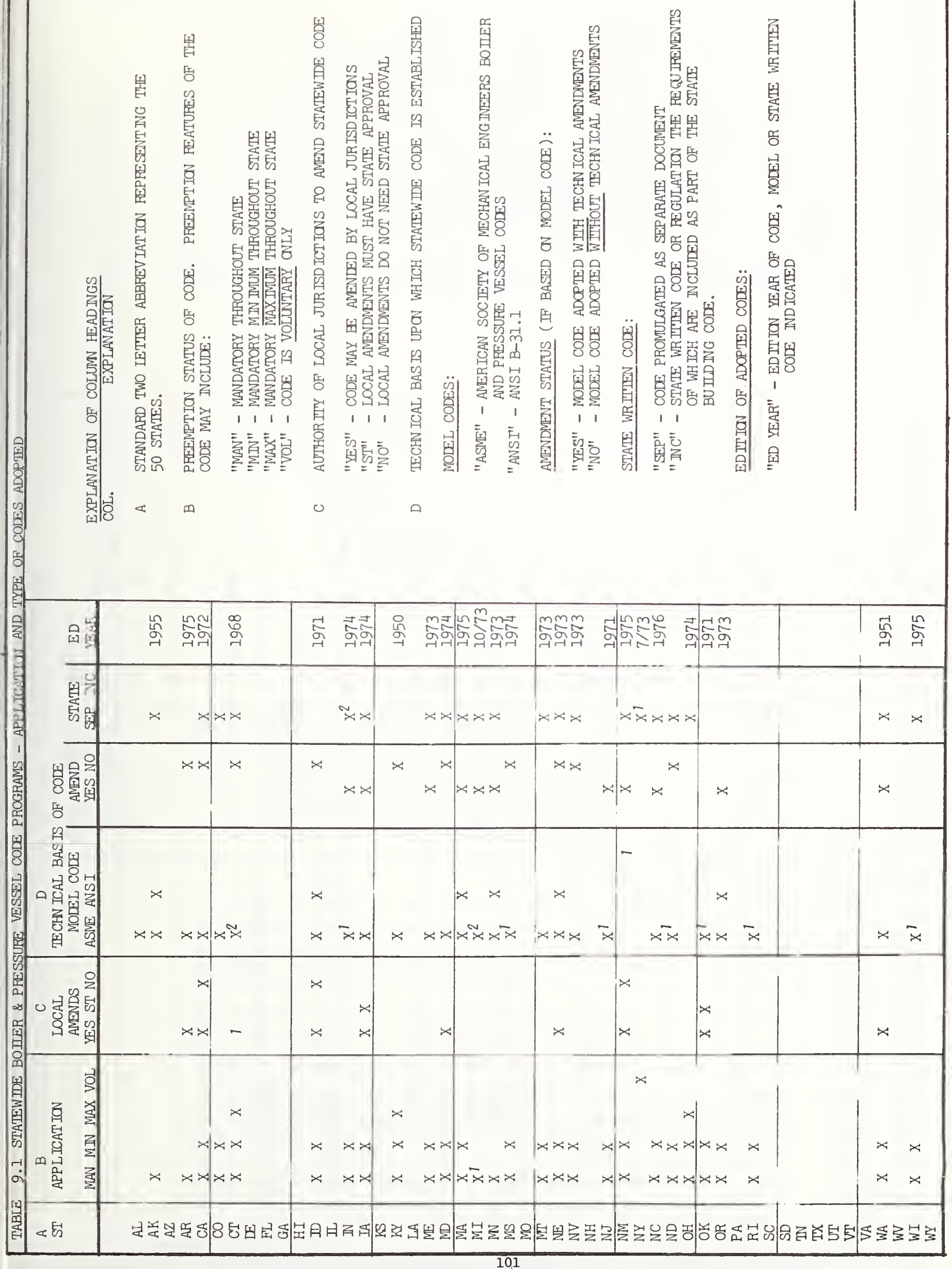




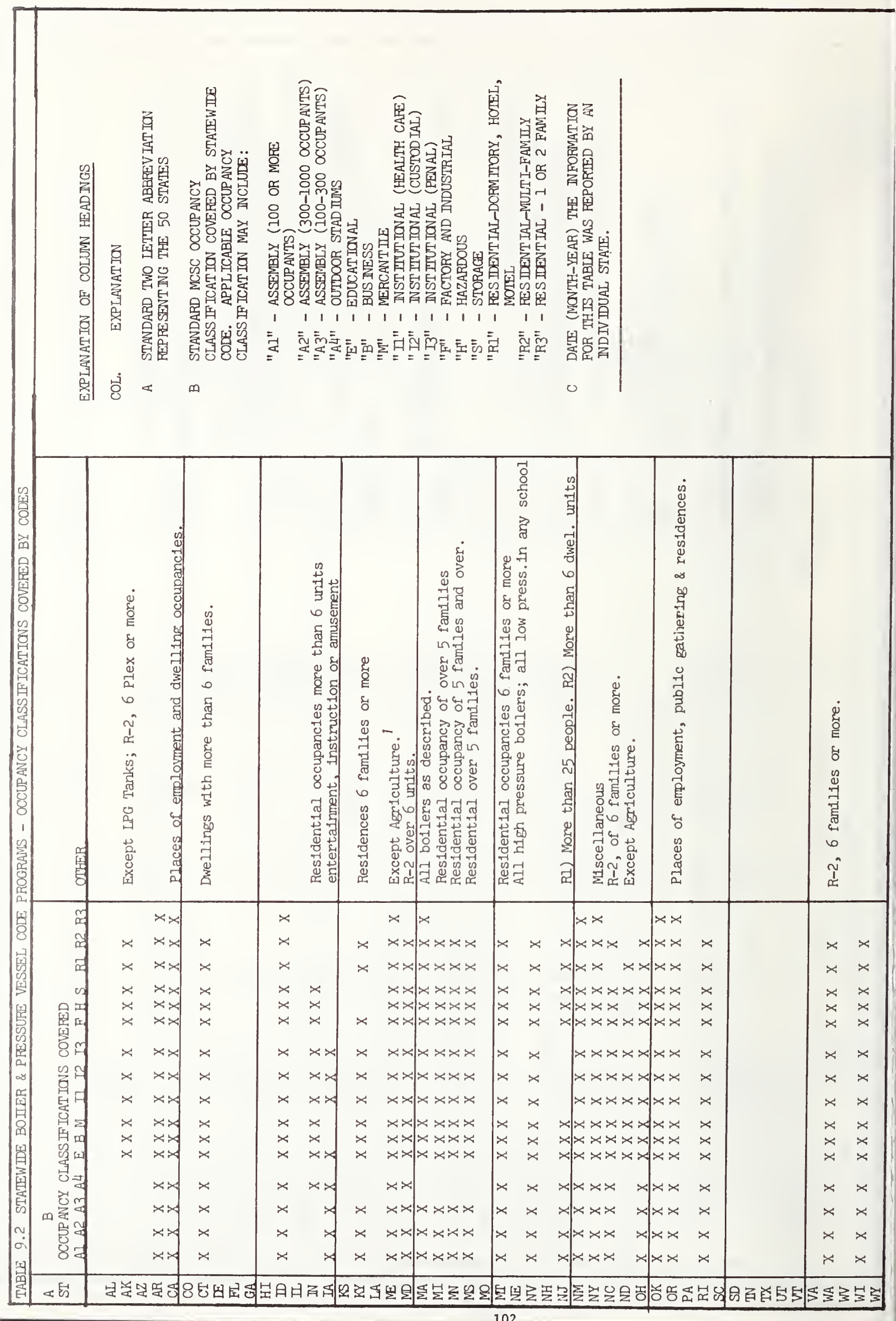




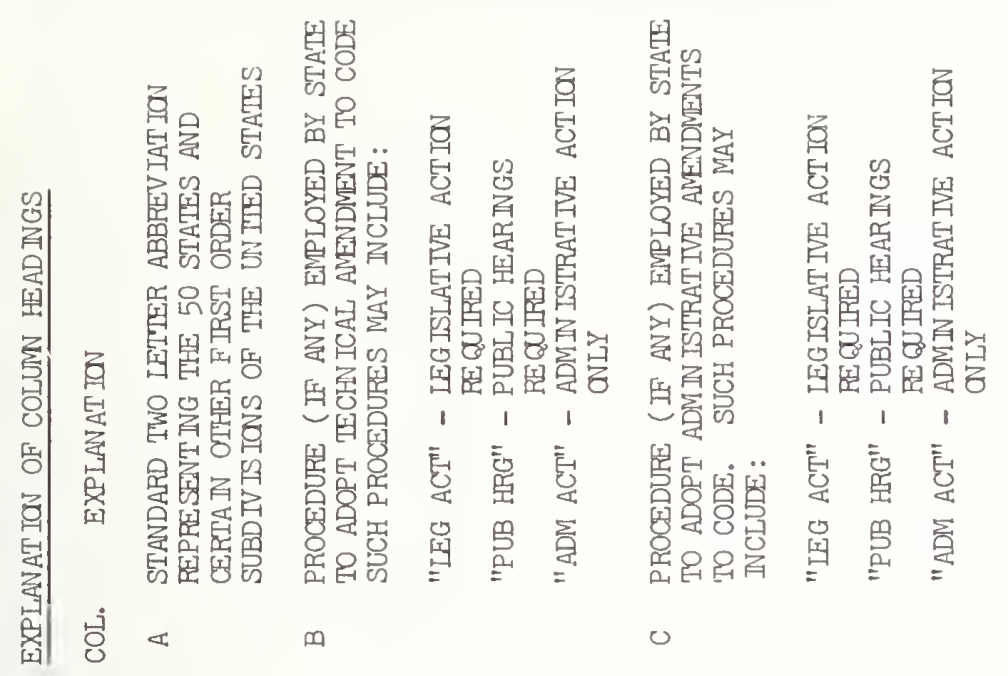




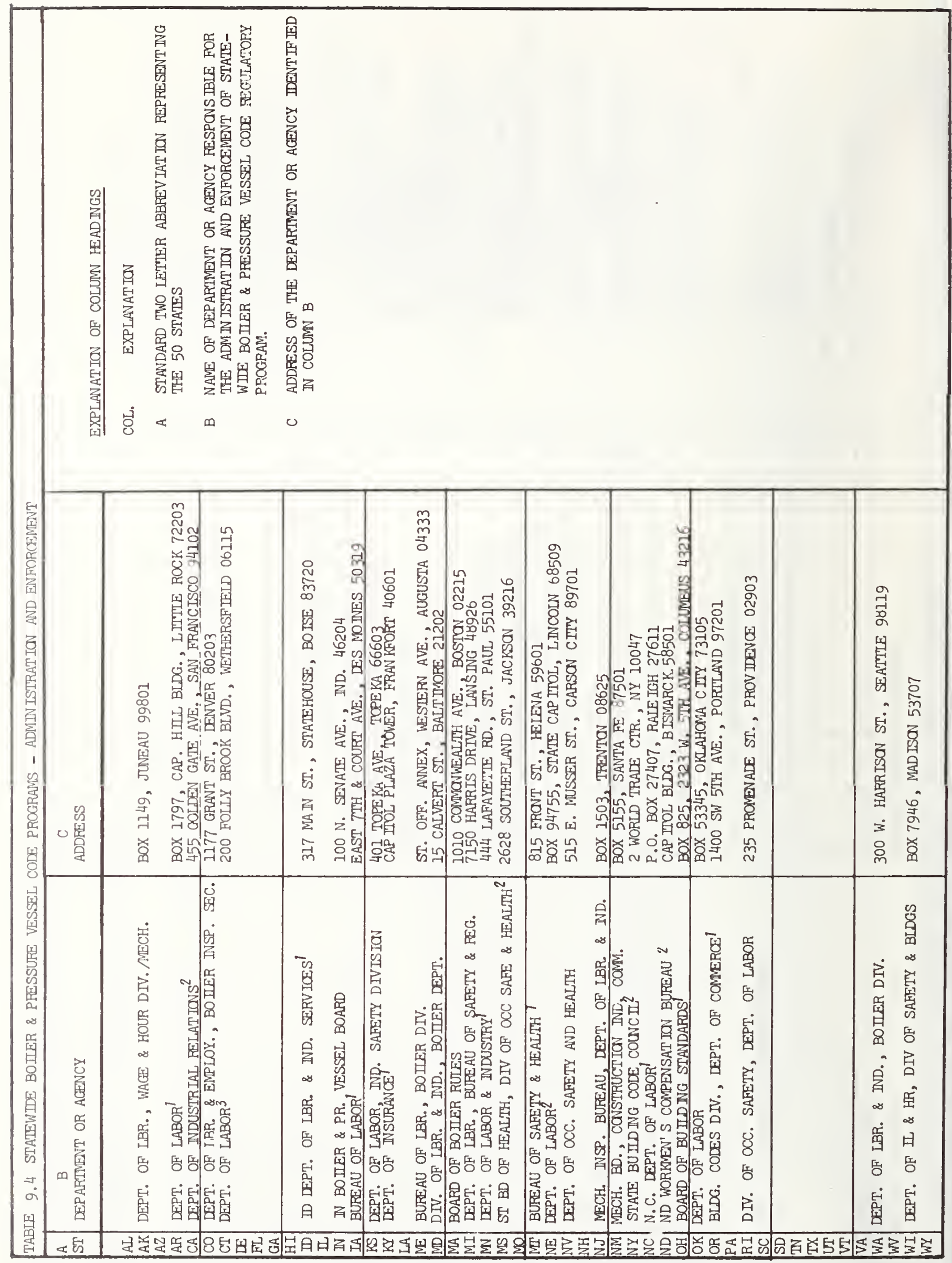




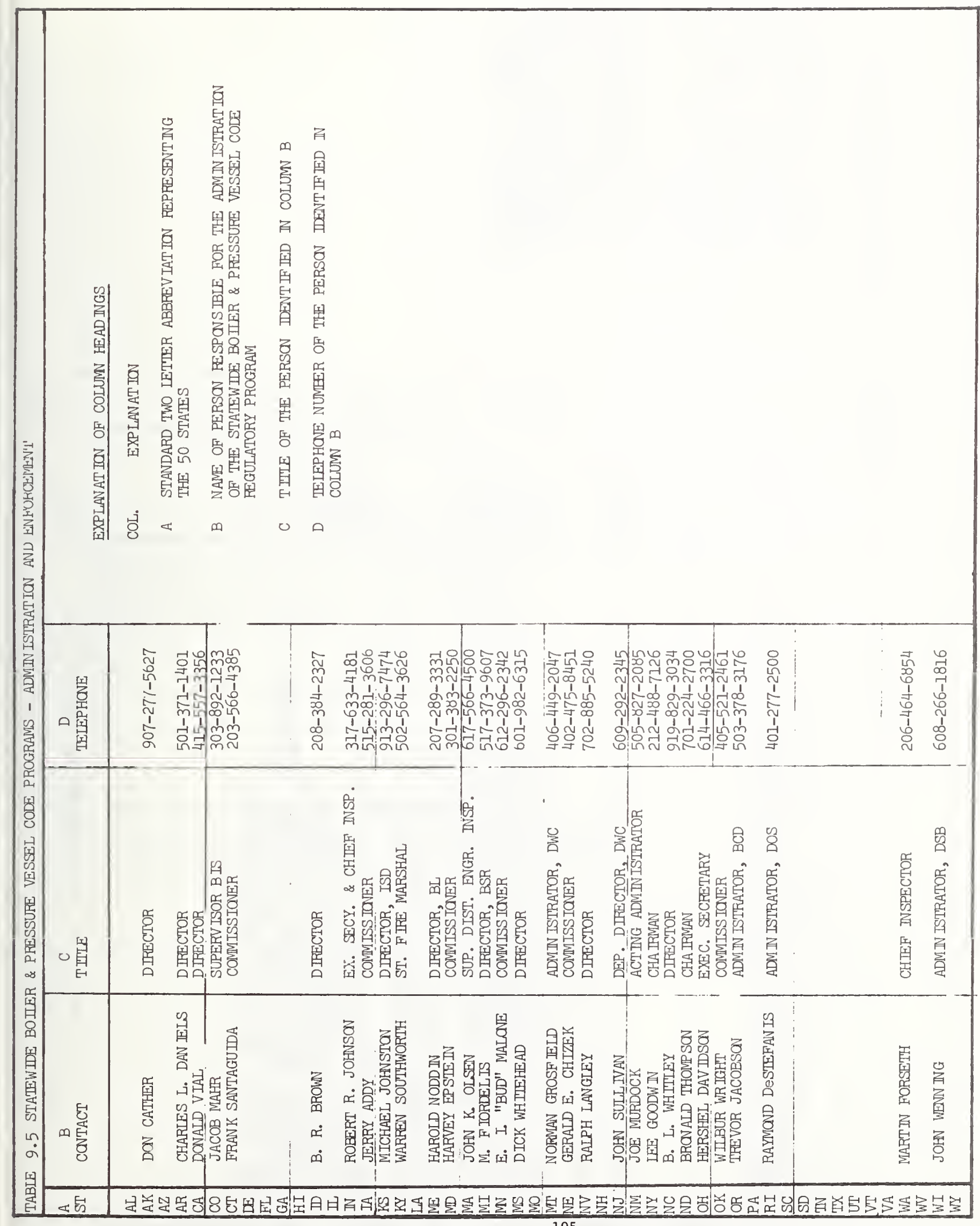




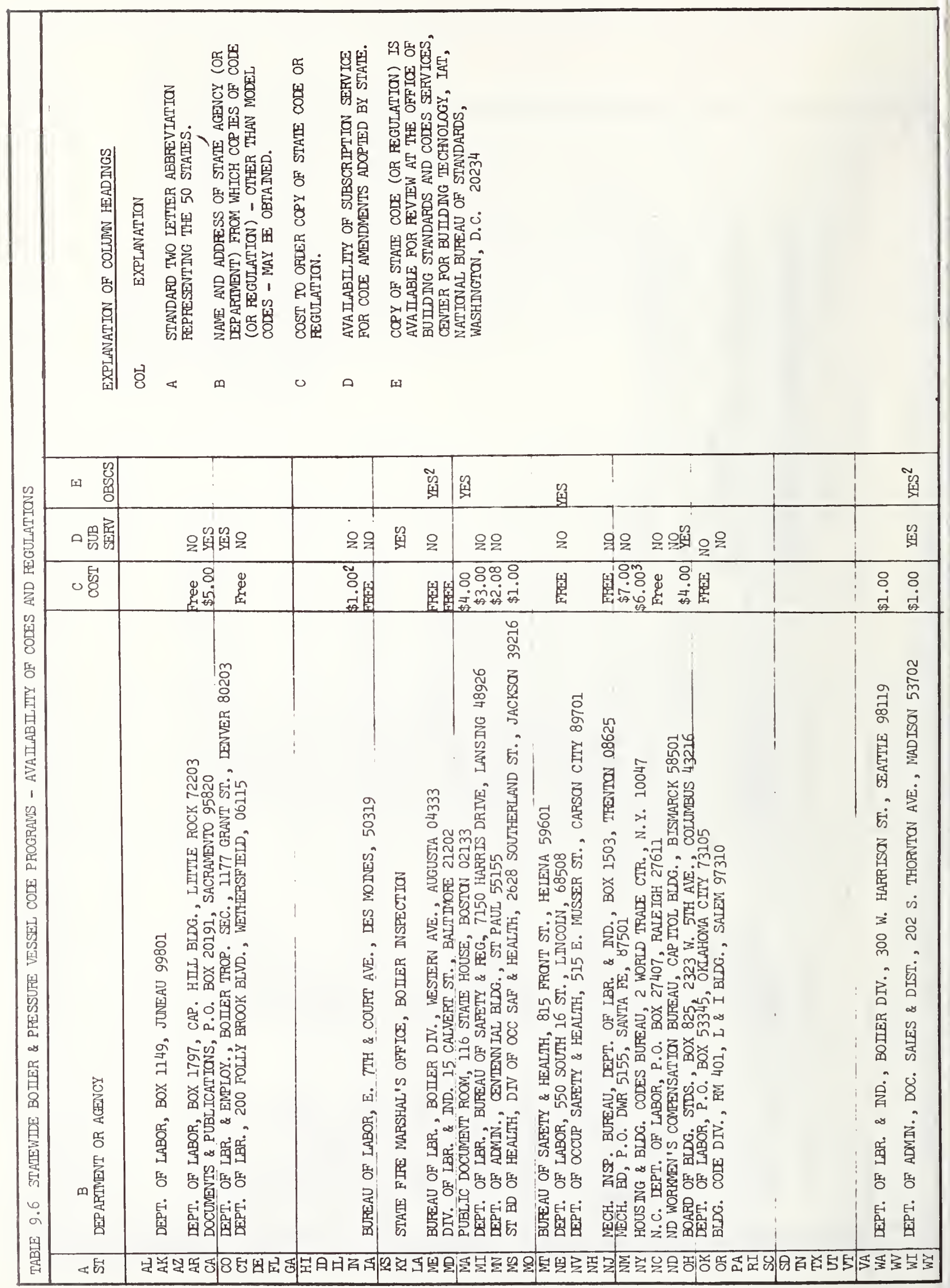


TABIE 9 STATEWIDE BOIIER \& PRESSURE VESSEI, CODES

NOTES, GENERAL REMARKS

AIABAMA

ALASKA

ARIZONA

ARKANSAS

1. Enforcement Agency: Dept. of Labor, Boiler Inspection Division, John Crosby, Chief Boiler Inspector, Capitol Hill Building, P.0. Box 1797, Little Rock 72203, (501) 371-1431.

CALIFORN IA

1. Also C.A.C. Title 25; Chap. I, Sec. 1075.

2. Enforcement Agency for places of employment - Department of Industrial

Relations, Division of Industrial Safety, R. Wilkins, Chief, (415) 557-1946.

Enforcement Agency for dwelling occupancies - Dept. of Housing and

Community Development, Div. of Codes and Standards, Xavier Miendoza, Chief, (916) 445-9471, Under T-25 CAC Ch. 1, Sec. 1075.

\section{COLORADO}

\section{CONNECTICUT}

1. Can only be amended by the State.

2. Sections 1-Ill-1 for hot water boilers only.

3. Enforcement Agency: Div. of Factory Inspection, Leo F. Alix, Deputy Commissioner.

DELAWARE

FLORIDA

GEORGIA 
TABIE 9 STATEWIDE BOIER \& PRESSURE VESSEL COLES (continued)

\section{HAWAII}

DAHO

1. Cities and counties have option for administration and enforcement under Section 39-4116, Idaho Code. Otherwise administration and enforcement by Idaho Department of Lator and Industrial Services

\section{IILINOIS}

\section{INDIANA}

1. Sections I, II, III, IV, V, VIII, IX of ASME Boiler and Pressure Vessel Codes adopted.

2. Rules and Regulations for Boilers \& Pressure Vessels.

IOWA

1. Enforcement Agency: Bureau of Labor, Boller Department, R. A. Hanson, Chief Boiler Inspector, (515) 281-3647.

\section{KANSAS}

\section{KENTUCKY}

1. Enforcement Agency: Dept. of Insurance, State Fire Marshal's Office, Boiler Inspection Section, Claude R. Woods, Chief Inspector, Capital Plaza Tower, Frankfort 40601. (502) 564-3626.

\section{LOUISIANA}

\section{MAINE}

1. Law covers all steam bollers over $15 \mathrm{psi}$ and all steam boilers, hot water heating or supply boilers located in any school or owned by a municipality.

2. 1969 Edition.

$$
\text { MAFIILAND }
$$

\section{MASSACHUSETTS}

1. Pressure Vessels delineated under Chapter 146, General Laws, Ter. Ed. 
TABLE 9 STATEWIDE BOIIER \& PRESSURE VESSEL CODES (contInued)

\section{MICHIGAN}

1. Cities with population over I million are exempt.

2. Sections I, II, III, IV, V, VI, VII, IX, X, XI of ASME Boiler and Pressure Vessel Codes adopted.

\section{MINNESOTA}

1. Enforcement Agency: Division of Boiler Inspection, Henry Bacon, Chief Inspector, (612) 296-4530.

\section{MISSISSIPPI}

1. Adopts ASME Boiler Code, Sections I, IV, VIII (I) and (2), X.

2. Occupational Safety and Health Division, Frank Manner, Chief Inspector, (601) $982-6315$.

\section{MISSOURI}

MONTANA

1. Enforcement Agency: Bureau of Safety and Health, Bernard Briggeman, Chief, (406) 449-3402.

\section{NEBRASKA}

1. Nebraska adopts Sections IV \& VIII of the ASME Boiler Code.

2. Under Statute $48-701$, the State Boiler Inspector is appointed every two (2) years under the direct supervision of the Commissioner of Labor.

NEVADA

NEW HAMPSHIRE

NEW JERSEY

1. All sections of ASME Boiler and Pressure Vessel Codes adopted.

NEW MEXICO

1. Uniform Mechanical Code.

NEW YORK

1. Part 5, Equipment Requirements of "General Building Construction."

2. Enforcement of State Building Construction Code is responsibility of municipalities.

3. $\$ 6.00$ for all four books of the State Building Construction Code. 
TABIE 9 STATEWIDE BOIIER \& PRESSURE VESSEL CODES (contInued)

$$
\text { NORTH CAROLINA }
$$

$$
\text { NORTH DAKOTA }
$$

1. Sections I, II, IV, VIII, (Divisions I \& II), IX of ASME Boiler and Pressure Vessel Codes adopted. Also North Dakota Boiler Rules and Regulations and an Unfired Pressure Vessel code under AI.2 of the North Dakota Industrial Safety Code.

2. Enforcement Agency: Division of Boiler Inspection, Harold J. Gragg, Chief Boiler Inspector.

\section{OHIO}

1. Enforcement Agency: Division of Boiler Inspection, Department of Industrial Relations, Ralph Yost, Chief, (614) 466-2/43.

OKLAHOMA

1. ASME Boiler Code, Sectionl, Power Boilers.

OREGON

1. Enforcement Agency: Boller and Pressure Vessel Section, Building Codes Division, D. R. Bartosch, Chief Boiler Inspector, (503) 229-5755.

\section{PENNSYLVAN IA}

RHODE ISLAND

1. ASME Boiler Code, Sections I, II a \& b, IV and IX.

SOUTH CAROLINA

SOUTH DAKOTA

TENNESSEE

IEXAS

UTAH 
TABIE 9 STATEWIDE BOIIER \& PRESSURE VESSEL CODES (contInued)

\section{VERMONT}

VIRGINIA

WASHINGTON

WEST VIRGINIA

WISCONSIN

1. ASME Boiler Code first adopted in 1957, latest edition 1971.

2. 1971 Edition.

WYOMING 


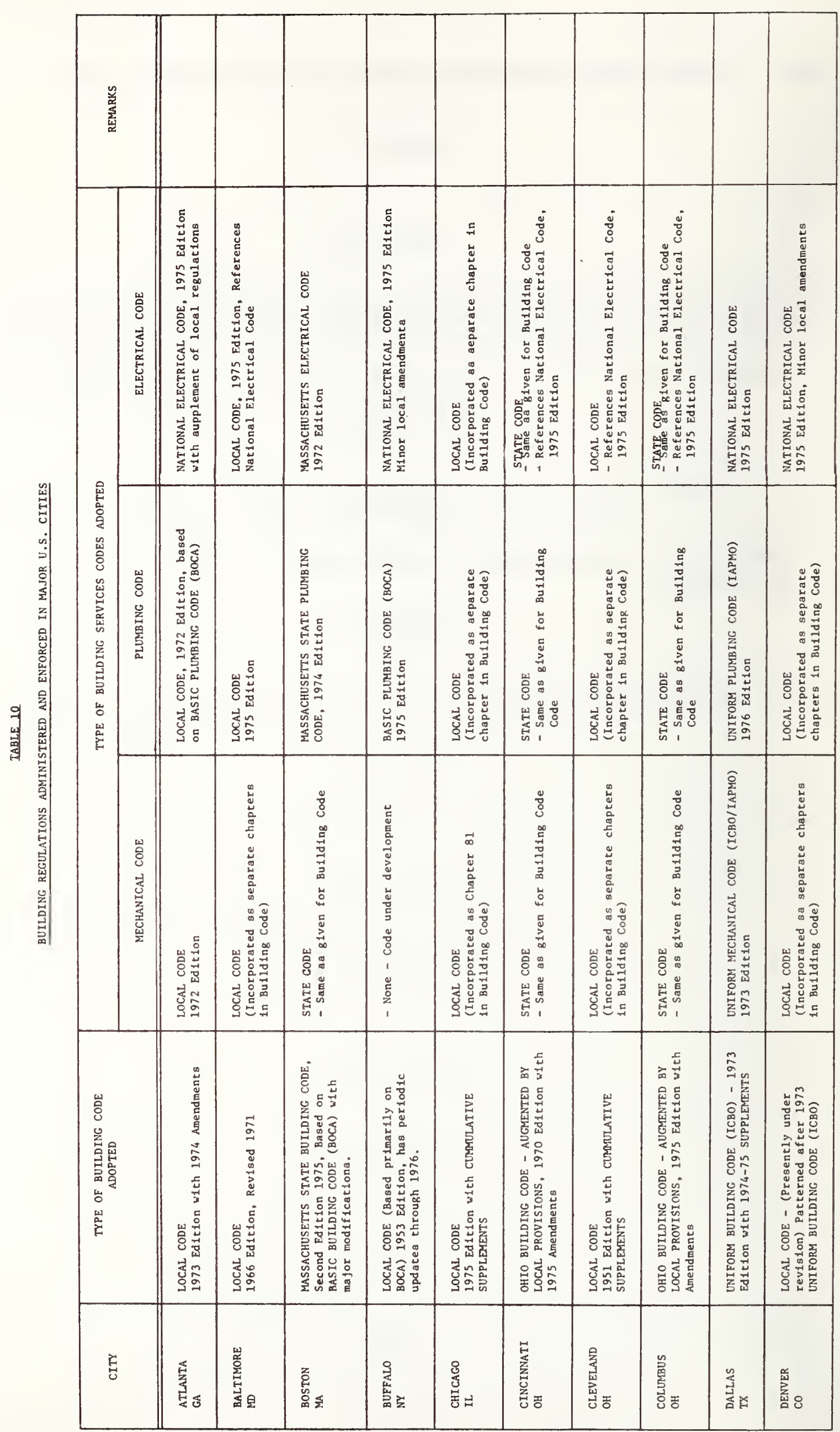




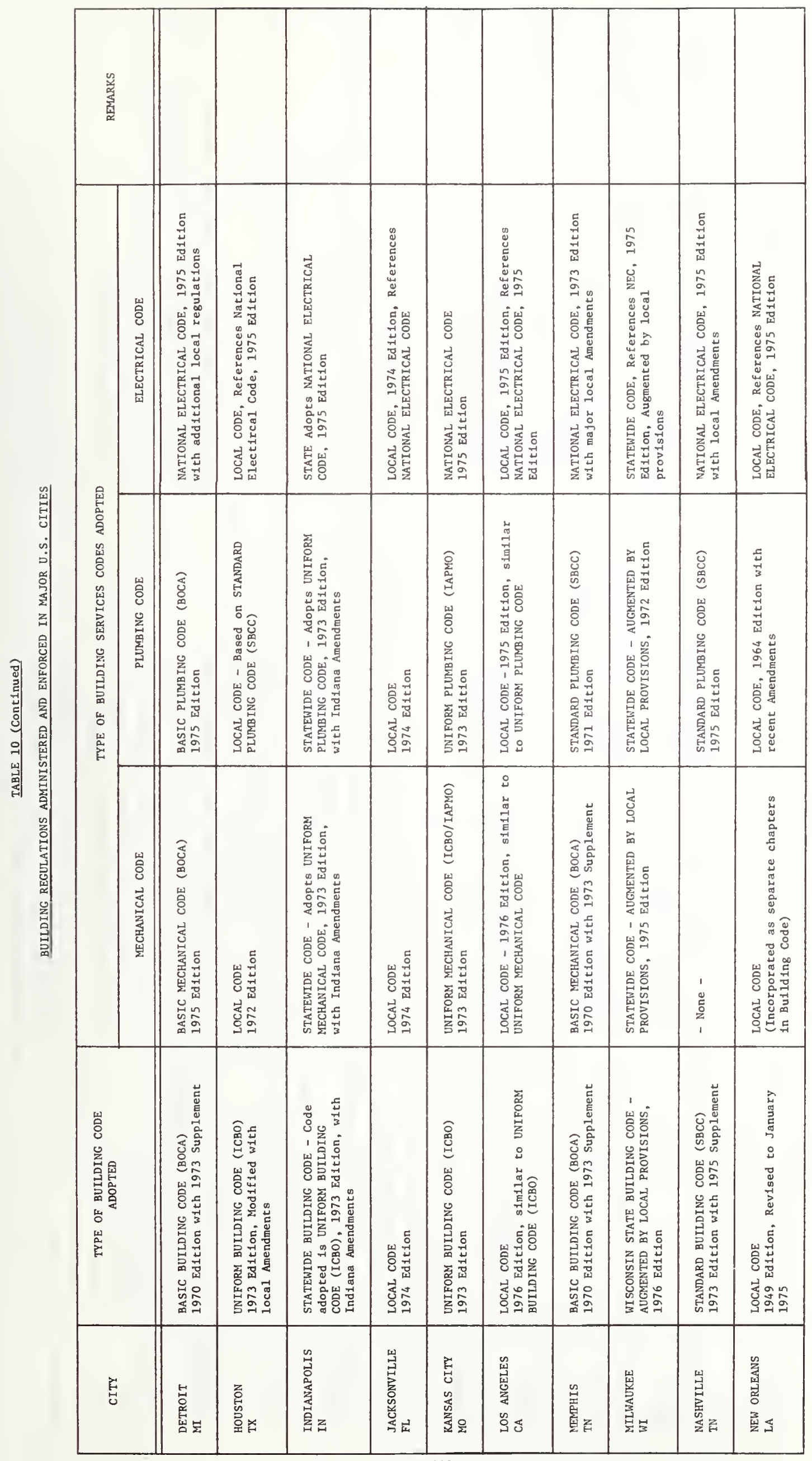




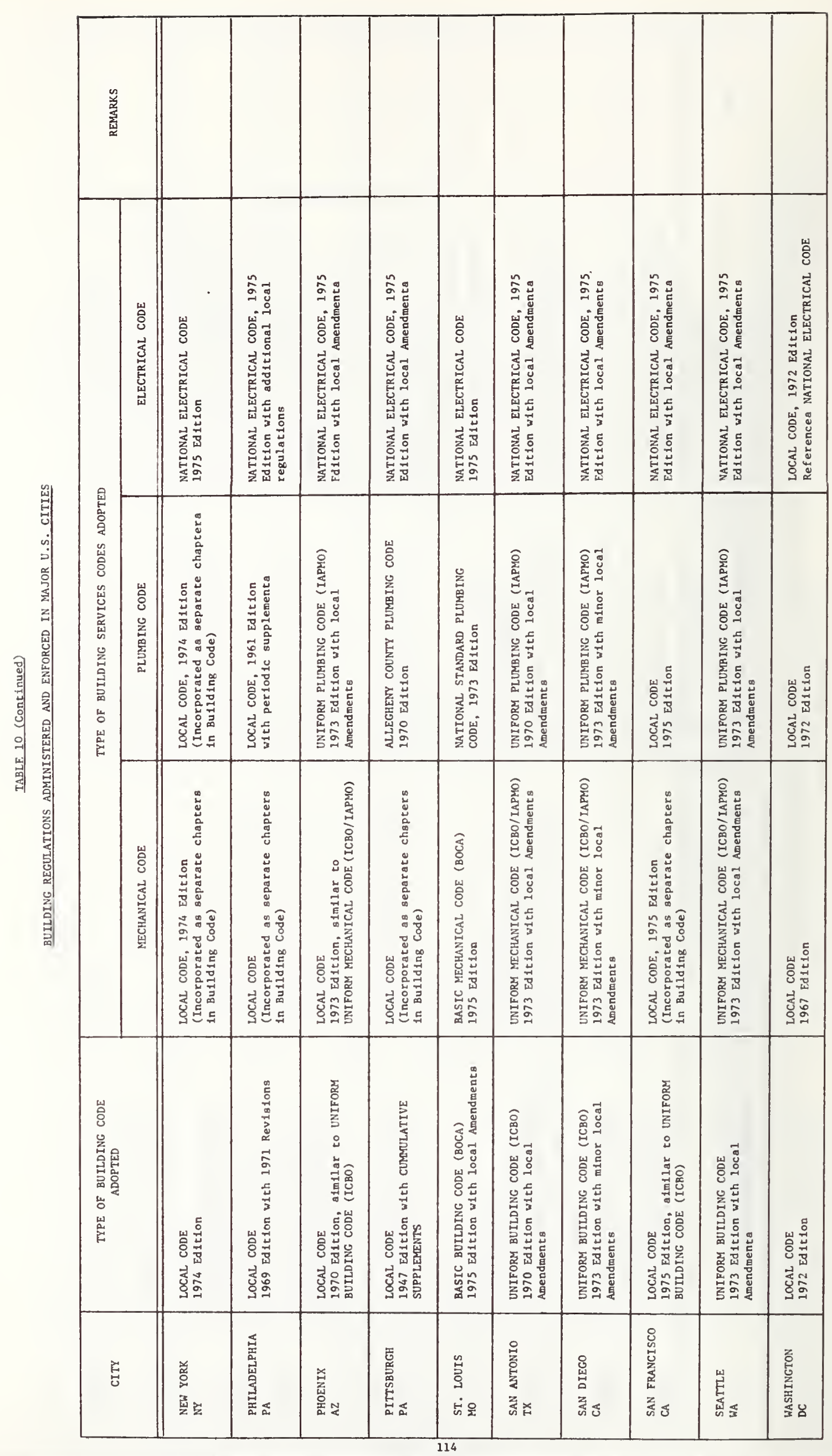




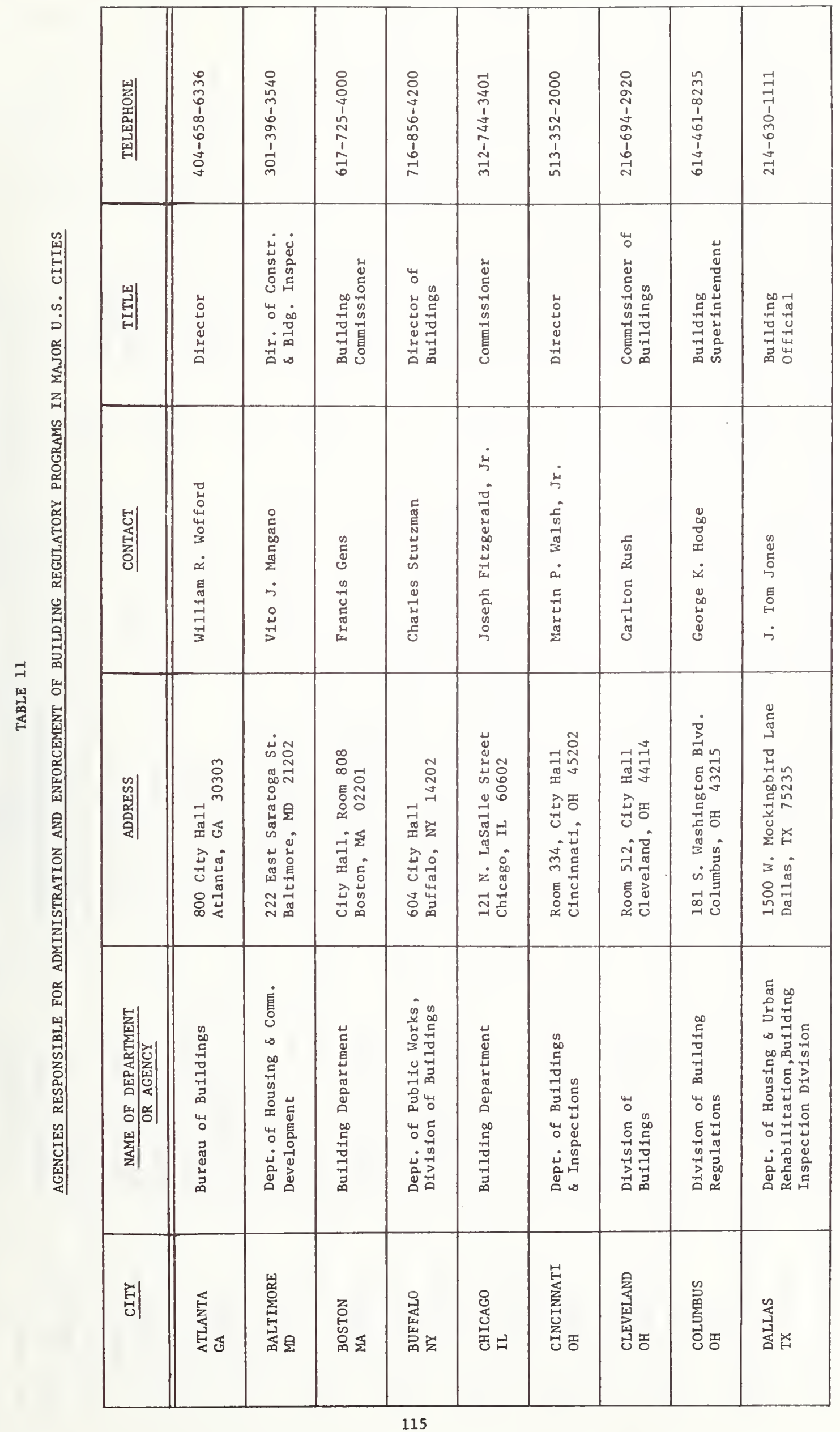




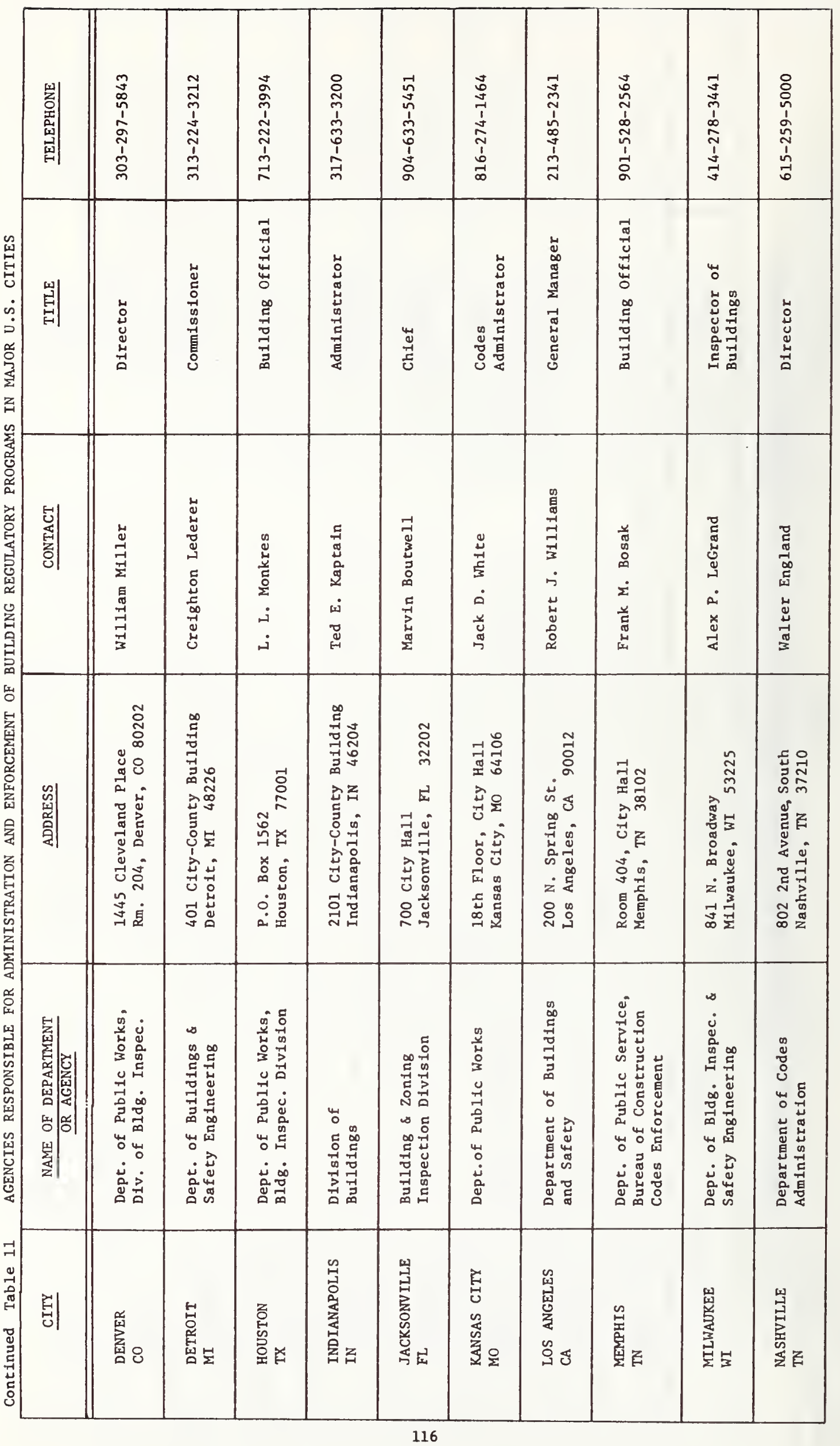




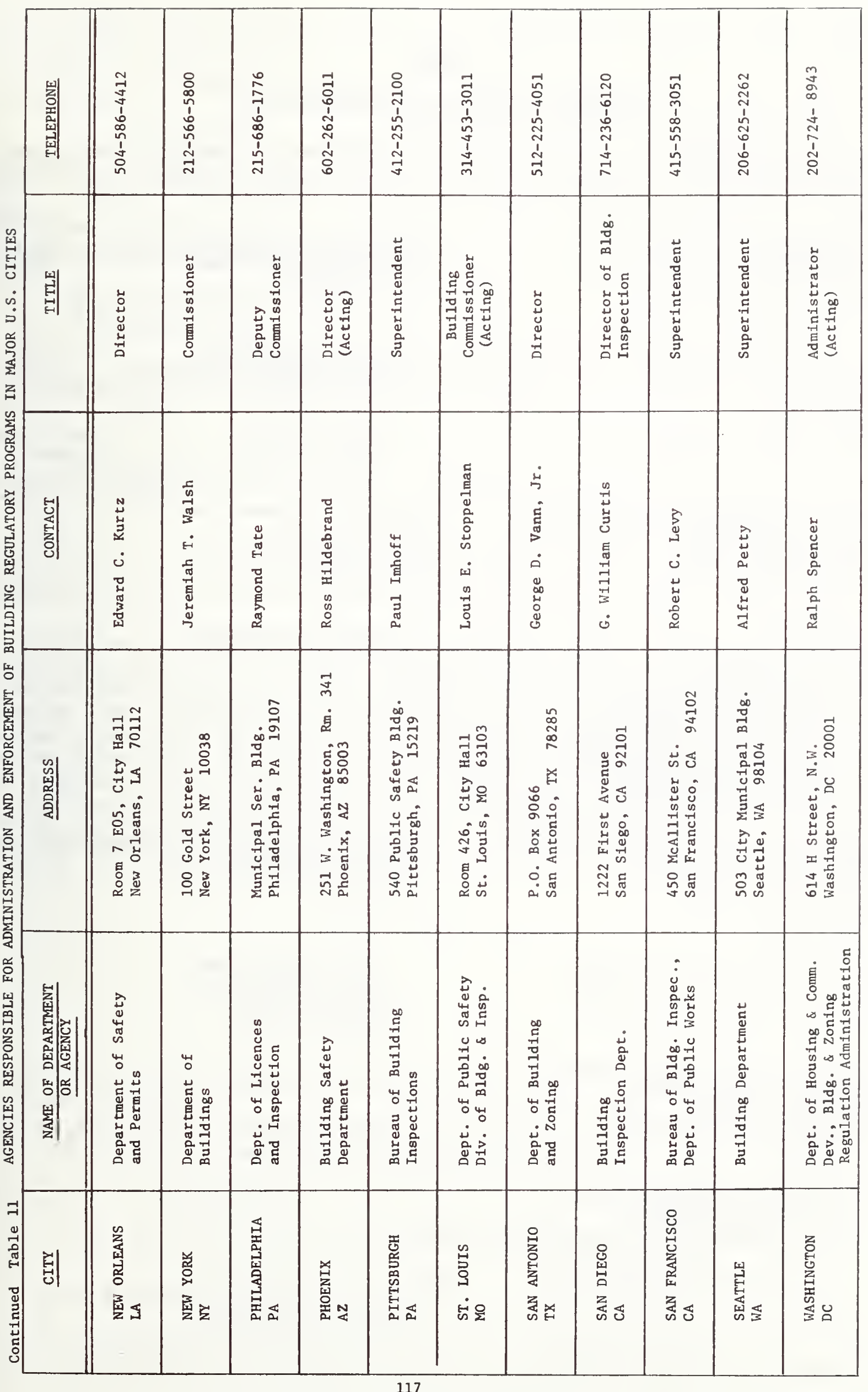


Following is a list of major organizations and the model codes that each organization publishes. This does not constitute a complete list. Only the codes that are most widely used throughout the Nation are Included.

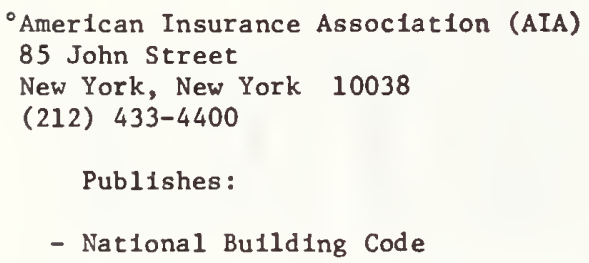

Publishes:

- MCSC L1st of Model Code Standards

- One and Two Fam11y Dwelling Code

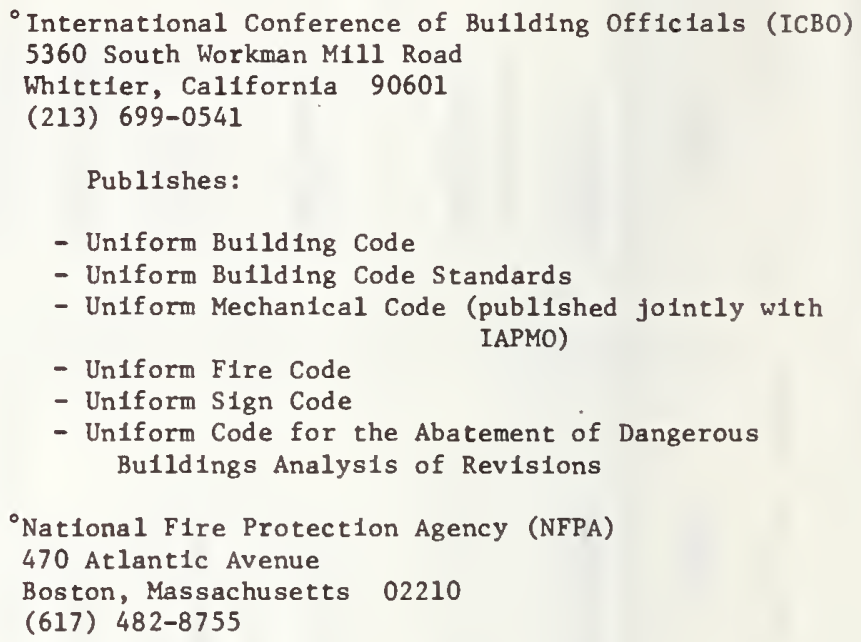

- Standard Gas Code

'International Association of Plumbing and Mechanical Officials (IAPMO)

5032 Alhambra Avenue

Los Angeles, Callfornia 90032

(213) 223-1471

Publ1shes:

- Uniform Plumbing Code

- Uniform Solar Energy Code

- Uniform Mechanical Code (published Jointly with ICBO) 


\begin{tabular}{|c|c|c|c|}
\hline $\begin{array}{l}\text { U.S. DEPT. OF COMM. } \\
\text { BIBLIOGRAPHIC DATA } \\
\text { SHEET }\end{array}$ & $\begin{array}{l}\text { 1. PUBLICATION OR REPORT NO. } \\
\text { NBSIR } 77-1390\end{array}$ & $\begin{array}{l}\text { 2. Gov't Accession } \\
\text { No. }\end{array}$ & 3. Recipient's Accession No. \\
\hline \multirow{2}{*}{\multicolumn{3}{|c|}{$\begin{array}{l}\text { A PRELIMINARY EXAMINATION OF BUILDING REGULATIONS } \\
\text { ADOPTED BY THE STATES AND MAJOR CITIES }\end{array}$}} & $\begin{array}{l}\text { 5. Publication Date } \\
\text { November } 1977\end{array}$ \\
\hline & & & 6. Performing Organization Code \\
\hline \multicolumn{3}{|l|}{ 7. AUTHOR(S) } & 8. Performing Organ. Report No. \\
\hline \multicolumn{3}{|c|}{$\begin{array}{l}\text { NATIONAL BUREAU OF STANDARDS } \\
\text { DEPARTMENT OF COMMERCE } \\
\text { WASHINGTON, D.C. } 20234\end{array}$} & 10. Project/Task/Work Unit No. \\
\hline \multirow{2}{*}{\multicolumn{3}{|c|}{ 12. Sponsoring Organization Name and Complete Address (Street, City, State, ZIP) }} & $\begin{array}{l}\text { 13. Type of Report \& Period } \\
\text { Covered } \\
\text { Preliminary }\end{array}$ \\
\hline & & & 14. Sponsoring Agency Code \\
\hline
\end{tabular}

15. SUPPLEMENTARY NOTES

16. ABSTRACT (A 200 word of less factual summary of most significant information. If document includes a significant bibliography of literature survey, mention it here.)

Preliminary information describing regulatory codes and standards bearing on building construction and occupancy which have been adopted by the various States and certain major citles in the U.S. are presented in a series of summary tables. The tables and accompanying notes provide information on salient elements of the enabling legislation, the type of codes and standards promulgated, and the respective agencies charged with the administration and enforcement of each regulatory program. Other features of the varlous regulatory programs (e.g., occupancy classifications covered, preemptive status of codes, etc.) are also enumerated. The regulatory programs and the respective code disciplines which are summarized include: building; mechanical; plumbing; electrical; fire and life safety; elevators; gas fittings; and boller and pressure vessels.

17. KEY WORDS (six to twelve entries; alphabetical order; capitalize only the first letter of the first key word unless a proper name; separated by semicolons)

Building construction; building regulations; cities; code uniformity; enforcement; legislation; rules and regulations; statewide codes; summary tables.

18. AVAILABILITY $\mathrm{X}$ Unlimited

$\square$ For Official Distribution. Do Not Release to NTIS

$\square$ Order From Sup. of Doc., U.S. Government Printing Office Washington, D.C. 20402, SD Cat. No.C13

$X$ Order From National Technical Information Service (NTIS) Springfield, Virginia 22151

\begin{tabular}{|l|c|}
\hline $\begin{array}{l}\text { 19. SECURITY CLASS } \\
\text { (THIS REPURT) }\end{array}$ & 123 \\
UNCL ASSIF IED & 21. NO. OF PAGES \\
\hline $\begin{array}{l}\text { 20. SECURITY CLASS } \\
\text { (THIS PAGE) } \\
\text { UNCLASSIFIED }\end{array}$ & 22. Price \\
$\$ 6.50$
\end{tabular}


